UNIVERSIDADE SE SÃO PAULO

FACULDADE DE FILOSOFIA, LETRAS E CIÊNCIAS HUMANAS

DEPARTAMENTO DE HISTÓRIA

\title{
GERMÁN ARCINIEGAS E A ARGENTINA, 1939-1960: MEDIAÇÕES CULTURAIS.
}

\author{
CARLOS DAVID SUÁREZ MORALES
}

SÃO PAULO

2015 
UNIVERSIDADE SE SÃO PAULO

FACULDADE DE FILOSOFIA, LETRAS E CIÊNCIAS HUMANAS

DEPARTAMENTO DE HISTÓRIA

Germán Arciniegas e a Argentina, 1939-1960: mediações culturais.

\section{CARLOS DAVID SUÁREZ MORALES}

Dissertação apresentada à Faculdade de Filosofia, Letras e Ciências Humanas da Universidade de São Paulo para obtenção do título de Mestre em História Econômica.

Orientador: Prof. Dr. Darío Horacio Gutiérrez Gallardo.

SÃO PAULO

Julho de 2015 


\section{Abstact}

This work analyses the intellectual relationships built by Colombian writer and diplomat Germán Arciniegas with Argentinian cultural institutions between 1939 and 1960. It focuses on cultural mediations arranged by him. Although initially his activities were related to diplomatic functions and contemplated the control of information about the Colombian government and the promotion of commercial deals, artistic and literary issues became what concentrated Arciniega's efforts to stimulate the dialogue and knowledge of the cultural traditions of both countries. Subsequently, Arciniegas continues to promote intellectual integration by articulating his own career and perspective of intellectual success with Argentinian publishers, becoming the Colombian consultant for the editors and transmitting an image of Argentinian history and culture to the Colombian journal El Tiempo's public. The work explores the political-ideological means of these activities and partnerships by the analysis of Arciniega's correspondence archive

\section{Resumo}

Nesta dissertação analisamos as relações culturais construídas pelo escritor e diplomata colombiano Germán Arciniegas com os meios intelectuais argentinos entre 1939 e 1960, concentrando o estudo nas mediações culturais promovidas por ele. No primeiro momento as atividades de Arciniegas estiveram relacionadas com as funções diplomáticas e contemplaram o controle de informação sobre o governo colombiano e a promoção de tratados comerciais. Mas foram assuntos relativos à arte a à literatura os que concentraram os esforços de Arciniegas para estimular o diálogo e o conhecimento das tradições culturais de cada país. No segundo momento Arciniegas continuou impulsionando a integração intelectual, articulando a própria carreira e as perspectivas da consagração aos editores argentinos, e transmitindo uma imagem da história e da cultura argentina ao público do jornal colombiano El Tiempo. 


\section{AGRADECIMENTOS}

A construção dessa dissertação não teria sido possível sem a colaboração e o apoio de muitas pessoas e instituições, às quais quero expressar o meu agradecimento.

Em primeiro lugar ao Dr. Horácio Gutiérrez, quem orientou generosamente o trabalho de pesquisa e redação, oferecendo sempre um diálogo aberto e leituras esclarecedoras. Seu trabalho de orientação veio acompanhado pela sua amizade e apoio durante esses anos de vida em São Paulo.

Os comentários das bancas de qualificação e defesa foram de muito valor para o resultado final da pesquisa. Agradeço as doutoras Maria Helena Capelato e Stella Maris Scatena Franco, e ao doutor José Luis Bendicho Beired. Também agradeço ao Dr. Alejandro Blanco da Universidade Nacional de Quilmes, orientou as minhas primeiras buscas por informações nas bibliotecas de Buenos Aires, e deu conselhos que se revelaram bem atentados no curso da pesquisa.

Agradeço aos colegas da Faculdade de Letras e Ciências Humanas da USP, com os quais construímos parcerias e amizades muito fecundas, especialmente a Marcela Cristina Quinteros, Marcio Robert, Júlio Canhada, Lidiane Soares Rodrigues, Ricardo Streich, Paulo Pina, Bianca Marcossi e Franco dela Valle. Agradeço a amizade e o estimulo intelectual do Dr. Miguel S. Palmeira, quem animou discussões muito importantes para o trabalho e para minha formação.

A Nuria Monelos agradeço o companheirismo e o afeto durante esses anos, suas leituras entusiastas e enriquecedoras. Aos grandes amigos Juan Calderón, Jáder Muniz, Marco Chandía, Carlos Rizzi, David Ramirez, Juan David Cadena, Diego Roa, Andrés Cuervo e Marcia Fernandes, pela disposição para escutar mil vezes a mesma história, ser leitores de primeira mão, corretores de estilo e tradutores.

Agradeço a Robinson López e Camilo Páez na Biblioteca Nacional de Colômbia em Bogotá, e ao pessoal na Academia Nacional de la História de la República Argentina, e da biblioteca da Faculdade de Filosofia e Letras da Universidade de Buenos Aires. À Capes, instituição de fomento da qual fui bolsista.

Finalmente aos meus Pais, Júlio e Isabel, a meu irmão Heimar, dos quais sempre tenho recebido todo o apoio para avançar nos meus estudos. 
Para Mariela (in memoriam) 


\section{SUMÁRIO}

$\begin{array}{ll}\text { INTRODUÇÃOO } & 8\end{array}$

$\begin{array}{ll}\text { Germán Arciniegas e as trocas intelectuais americanas } & 9\end{array}$

$\begin{array}{ll}\text { A historiografia sobre Germán Arciniegas } & 13\end{array}$

$\begin{array}{ll}\text { Mediações e mediadores culturais } & 17\end{array}$

$\begin{array}{lr}\text { Proposta de análise } & 19\end{array}$

$\begin{array}{ll}\text { Fontes } & 20\end{array}$

$\begin{array}{ll}\text { Organização da dissertação } & 25\end{array}$

PRIMEIRA PARTE. GERMÁN ARCINIEGAS DIPLOMATA E INTELECTUAL

$\begin{array}{ll}\text { NA ARGENTINA, 1939-1941 } 27 & 27\end{array}$

$\begin{array}{ll}\text { Introdução } & 27\end{array}$

Capítulo 1. Afinidades do trabalho do escritor e diplomata 29

$\begin{array}{ll}\text { O duplo prestígio } & 29\end{array}$

$\begin{array}{ll}\text { Trabalho diplomático e jornalismo } & 34\end{array}$

$\begin{array}{ll}\text { Respaldo material } & 38\end{array}$

$\begin{array}{ll}\text { A casa da embaixada } & 39\end{array}$

$\begin{array}{ll}\text { Ganhar amizades } & 41\end{array}$

Capítulo 2. O trabalho diplomático de Germán Arciniegas na Argentina 43

$\begin{array}{ll}\text { Introdução } & 43\end{array}$

Exposições de arte. A mediação cultural como pedagogia e formação do

$\begin{array}{ll}\text { público } & 43\end{array}$

A exposição do livro e a arte colombiana. Mediação e diplomacia cultural $\quad 48$

A estátua de Santander. Mediação e promoção do liberalismo colombiano 58

$\begin{array}{lr}\text { Tratados comerciais. A integração americana. } & 64\end{array}$ 
A política argentina nas cartas de Arciniegas.

SEGUNDA PARTE. GERMÁN ARCINIEGAS E A ARGENTINA: EDITORAS, IMPRENSA

$\begin{array}{ll}\text { E VIAGEM, 1940-1960. } & 75\end{array}$

$\begin{array}{ll}\text { Introdução } & 75\end{array}$

Capítulo 3. Germán Arciniegas e as editoras argentinas, 1940-1960 76

$\begin{array}{ll}\text { Introdução } & 76\end{array}$

A edição dos primeiros livros de Arciniegas e sua penetração continental 77

Edições coleções editoriais e colaboração intelectual $\quad 81$

Mercado latino-americano do livro $\quad 92$

$\begin{array}{ll}\text { Conclusões } & 100\end{array}$

Capítulo 4. A Argentina traduzida por Germán Arciniegas. 103

$\begin{array}{ll}\text { Introdução } & 103\end{array}$

La “Calle Rivadavia” 106

$\begin{array}{ll}\text { As telhas e a questão da tradição } & 110\end{array}$

$\begin{array}{ll}\text { Cenas democráticas } & 113\end{array}$

Os criados, as calças, o sotaque: ordem, riqueza, disciplina. $\quad 115$

$\begin{array}{lr}\text { La Boca, força e latinidade } & 120\end{array}$

$\begin{array}{ll}\text { O rio e o ar de Buenos Aires } & 122\end{array}$

$\begin{array}{ll}\text { Conclusões } & 125\end{array}$

$\begin{array}{lr}\text { Conclusões } & 128\end{array}$

$\begin{array}{ll}\text { Bibliografía } & 134\end{array}$ 


\section{INTRODUÇÃO}

Germán Arciniegas foi um escritor, político e diplomata colombiano, bogotano, que viveu entre 1900 e 1999, e foi autor de uma imensa obra que chega a mais de 50 livros, além de inúmeros artigos em revistas literárias e jornais. Sua trajetória indica um percurso internacional excepcional entre os escritores colombianos até os anos 1970, tendo morado na Inglaterra, Estados Unidos, Argentina, Itália, Israel e Romênia, muitas vezes como funcionário diplomático. Essa caraterística de sua trajetória tem um desdobramento em sua obra, focada na elucidação do sentido da história americana, e da "identidade" continental, que Arciniegas farejava nos lugares do mundo que conhecia como o intenso viajante que foi, e que transmitiu não só em livros de ensaios, mas em crônicas de viagem e artigos de jornal escritos no decorrer de quase oitenta anos. Sua obra constituiu um esforço para reconhecer os elementos culturais e históricos que identificam aos povos e nações das Américas, desde os Estados Unidos e o Canadá até as Antilhas, o mundo hispano-americano e o Brasil.

Além disso, Arciniegas foi um intelectual comprometido com a integração intelectual do continente americano. Em vários momentos de sua vida, o escritor colombiano se vinculou, assessorou e mesmo dirigiu às mais variadas empresas de cultura: revistas, editoras, associações de escritores e artistas, que procuraram construir pontes entre as comunidades letradas dos países americanos. Ao mesmo tempo a trajetória de Arciniegas foi marcada pelos contatos que manteve com alguns campos intelectuais do continente além do colombiano, especialmente o argentino, o mexicano e o dos Estados Unidos.

Nesta dissertação pretendemos compreender as relações construídas por Germán Arciniegas e os âmbitos intelectuais argentinos nas décadas de 1940 e 1950, e analisar as pontes que o escritor se propôs criar entre esses e os espaços letrados da Colômbia, colocando em diálogo as comunidades de escritores e artistas de ambos os países, suas produções contemporâneas e suas tradições. É nesse sentido que temos nos proposto a compreender o americanismo $^{1}$ do escritor -

\footnotetext{
${ }^{1}$ Entendemos assim o americanismo não apenas como apenas um discurso mas como uma prática que implicava a circulação, a integração e o diálogo efetivo entre os intelectuais e artistas americanos e suas tradições culturais. Bergel, Martín, Martínez Mazzola, Ricardo, América Latina como práctica. Modos de sociabilidad intelectual de los reformistas universitários (1918-1930). Em: Altamirano, Carlos (dir) Historia de los intelectuales en América Latina. Vol. II. Madrid, Katz, 2010. pp. 119-145; Rojas, Rafael. "Las desventuras de un género". Prismas. Revista de Historia Intelectual. Quilmes. 2007.
} 
na sua obra e na sua trajetória -, como um exercício de mediação cultural, e não apenas como um discurso sobre a identidade cultural do continente.

\section{Germán Arciniegas e as trocas intelectuais americanas.}

A trajetória do escritor e político colombiano pode remeter a três processos da história cultural dos países latino-americanos. O primeiro deles é a pergunta pela identidade que muitos escritores e artistas da região desenvolveram durante a primeira metade do século $\mathrm{XX}$, e a circulação transnacional de ideias que acompanhou sua produção. O segundo é o crescimento dos âmbitos letrados, a consolidação de empresas, instituições e mercados para os bens culturais, embora o movimento não fosse homogêneo em todos os países. O terceiro elemento é a formação de redes de colaboração e as empreitadas de iniciativas tanto privadas quanto oficiais de intercâmbio e cooperação artística e intelectual, nas quais diferentes orientações políticas e culturais foram colocadas em jogo.

É claro que nesses três processos o papel de alguns intermediários resultou fundamental. Intelectuais e artistas latino-americanos das primeiras décadas do século XX questionaram as identidades nacionais e começaram a construção de um diálogo sobre as identidades regionais e continentais. Sua atividade estabeleceu uma intervenção sobre o repertório -ou arquivo- de imagens sobre "o americano" que acabou sendo decisiva na formação das identidades "americanas" pela circulação de que foram objeto e pela adoção institucional que receberam, sendo criadas e recriadas por pintores, ensaístas, romancistas, poetas, cineastas e dramaturgos, entre outros criadores de bens culturais como também ocorreu com outro tipo de identidades coletivas, em especial as nacionais e regionais, no mesmo período.

Querendo entender a atividade de Arciniegas neste processo de circulação deve-se romper desde o começo com os limites dos vieses estritamente nacionais e problematizar sua atuação como intermediário, visando compreender as circunstâncias, estratégias que lhe permitiram apropriar-se de "ideias e imagens produzidas em outros espaços, reelaborando-as de forma particular", e ver como "esse produto novo, por sua vez, se integra ao circuito internacional onde é reproduzido de diferentes maneiras por diferentes agentes", como assinala a historiadora Maria Helena Capelato, 
acrescentando que "a recepção de um imaginário que representa uma identidade específica extrapola, portanto, os quadros nacionais",2.

Embora no século XIX já tivesse avançado no caminho da interpretação da identidade americana como uma instância comum às nações do continente, foi só no começo do século XX que a circulação de idéias e imagens se tornou mais estreita e intensa. Nas palavras do crítico colombiano Rafael Gutiérrez Girardot "la inquietud puesta en marcha por estos hombres adquirió forma de torrente y hubo una época en que parecía escucharse un coro de voces americanas entonando una misma pregunta: ¿qué es América?"3. A longa configuração de redes de intelectuais e artistas americanos que pudessem efetivamente atuar como intermediários culturais é um aspecto fundamental da história da construção da identidade americana. Jorge Myers, no artigo citado já acima, acerta ao dizer que:

\begin{abstract}
"Essa acumulação prévia [de interpretações sobre a identidade cultural das nações da América] fora feita em vários dos principais países da região - México, Brasil, Peru, Argentina, Cuba - e também nas antigas metrópoles, sobretudo na Espanha. No entanto, a intensa atividade de ensaístas, historiadores e críticos, que logo serviu de insumo e suporte a essa nova história cultural [que apareceria ao começo do século vinte], ocorreu muitas vezes de um modo isolado, alheio às reflexões e à investigação que se estavam produzindo noutras nações latino-americanas. É por esse motivo que a constituição progressiva de distintas redes culturais - cada vez mais cruzadas entre si - foi decisiva para que se criassem as condições de possibilidade desse empreendimento cultural. Sem a circulação de saberes, sem a troca de olhares e de experiências que essas redes de indivíduos e grupos permitiram, não teria sido possível a emergência de uma perspectiva histórico-
\end{abstract}

${ }^{2}$ Capelato Rolim, Maria Helena. Modernismo latino-americano e construção de identidades através da pintura. Revista de História. São Paulo. No. 135. 2005-2. pp. 251-282. Algum rastro daquela circulação de idéias e imagens sobre a América Latina na obra de Arciniegas já foi insinuado nas "afinidades" entre sua poética ensaística e a do mexicano Alfonso Reyes, estudadas pelo critico literário James Wills Robb. "Imágenes de América en Alfonso Reyes y en Germán Arciniegas", Humanitas, Monterrey, 1964, págs. 255-269; "Variedades del ensayismo en Alfonso Reyes y Germán Arciniegas" Thesaurus. Tomo XXXVI. Bogotá. 1981. Segundo o historiador Jorge Myers pode-se dizer que Arciniegas como outros intelectuais do continente compartilhou com Alfonso Reyes "a vontade de criar imagens sintéticas que servissem para condensar toda uma interpretação altamente complexa da cultura nacional observada (..) e sua relação com a América Latina". Em sua opinião "Essa vontade de plasmar em "figurações" a interpretação da realidade cultural do continente latino-americano seria o eixo em torno do qual se articularia o projeto da história cultural, promovido quinze anos mais tarde por toda essa falange de escritores integrados ao circuito lábil e permanente de intercâmbios que o sistema epistolar do diplomata mexicano soube ser, permitiu-lhe aprofundar e refinar sua visão da cultura latino-americana [...]."Myers, Jorge, Gênese "ateneísta" da história cultural latino-americana. Em: Tempo social. Revista de sociologia da USP, 17. São Paulo. 2005. Sobre a presença destas imagens na obra de Germán tem se detido alguns estudiosos e críticos da sua produção intelectual. Triviño Anzola, Consuelo. De Montaigne a Arciniegas: la escritura y la construcción del ser americano. Cuadernos Hispanoamericanos 551-552, pp. 61-70; Cobo Borda, Juan Gustavo. Germán Arciniegas. En: Silva, Arciniegas, Mutis, García Márquez y otros escritores colombianos. Bogotá: Biblioteca Familiar de la presidencia de la República. 1997.

${ }^{3}$ Gutierrez Girardot, Rafael. La imagen de América en Alfonso Reyes.Madrid. ínsula: 1955, p. 12 
cultural compartilhada ou pelo menos convergente e muito menos a constituição de uma formação cultural ligada por uma estrutura de sentimento compartilhada (...)"4. .

Algumas iniciativas como seleções editoriais ou revistas são exemplos disso. Sem adiantar muito, pode-se lembrar duas séries dos anos 40: Tierra Firme, do FCE, sediada na cidade de México, e a Biblioteca del Pensamiento Vivo, da Editorial Losada, sediada em Buenos Aires. Nessas Arciniegas participou com seu Este pueblo de América (FCE, México D.F, 1945), e El pensamiento vivo de Andrés Bello (Losada, Buenos Aires, 1946) ${ }^{5}$. Também na mesma década Arciniegas entrou em contato com duas importantes revistas do continente: Sur, de Buenos Aires, e Cuadernos Americanos, da cidade de México. Estes quatro exemplos de empresas culturais nos quais Arciniegas colaborou, são amostras importantes da mobilização de redes construídas a partir de diferentes campos intelectuais e ao redor de intermediários ${ }^{6}$. Estes casos mostram também o impulso que tiveram nestes anos as propostas americanistas em diferentes círculos intelectuais do continente, incluindo os Estados Unidos ${ }^{7}$.

Mas a integração que operava essas redes não vinculava âmbitos com as mesmas condições. Se, com particular força, a partir da década de 1930, diferentes países da região experimentaram o revigoramento de seus âmbitos letrados, como revistas, editoras, estudos universitários, e o próprio mercado de bens culturais e de alfabetização, isso não aconteceu com a mesma intensidade em todos os espaços do continente. Com efeito, o exílio espanhol decorrente da guerra civil abriu um espaço para as empresas culturais americanas, nas quais os exilados tomaram parte, e inclusive dirigiram, configurando assim uma conjuntura de autonomia dos

\footnotetext{
${ }^{4}$ Myers, Jorge. "a gênese..." Op. Cit. p. 21.

${ }^{5}$ A obra de Arciniegas também mereceu depois, nos anos 1990, um volume na coleção Ayacucho, na Venezuela, uma ambiciosa iniciativa editorial que visa abranger os cumes da produção intelectual latino-americana.

${ }^{6}$ Myers afirma, por exemplo, que "a galáxia de circuitos transnacionais de intercâmbio cultural da qual emergiria o projeto "Tierra Firme" da FCE [Fondo de Cultura Económica], correspondeu aos deslocamentos geográficos e à simultânea construção de uma ampla rede epistolar e de intercâmbios acadêmicos por parte de três dos membros do círculo "ateneísta"“. (Myers, Jotge. "a gênese..." Op. Cit. p. 21. Sem contar aqui com a rede de Victoria Ocampo que Arciniegas reconheceu como fundamental para sua carreira.

${ }^{7}$ Myers, Jorge. "a gênese..." Op. Cit; Sarlo, Beatriz. La perspectiva americana en los primeros años de Sur. En: Altamirano, Carlos y Sarlo, Beatriz. Ensayos Argentinos. De Sarmiento a la vanguardia. Buenos Aires. Ariel. 1997. Pp. 261-268; Bethell, Leslie. O Brasil e a idéia de "América Latina" em prespectiva histórica. Estudos históricos Vol. 22. No. 44; Hanke, Lewis, ¿Tienen las Américas una Historia común? México. Editorial Diana. 1996; Pita, Alexandra. La discutida identidad latinoamericana: debates en el Repertorio Americano, 1938-1945. En: GRANADOS, Aimer y MARICHAL, Carlos (coordinadores). Construcción de la identidad latinoamericana. Ensayos de historia intelectual. Siglos XIX y XX. México: El Colegio de México. 2004. Pp. 241-263
} 
campos literários e editoriais latino-americanos perante a Espanha, autonomia e liderança que já vinham sendo contestadas desde a década de $1920^{8}$. Mas, como foi dito, o processo de autonomia e crescimento dos campos intelectuais que iam se consolidando no continente, não foi homogêneo, e pelo contrário conduziu à aparição de novos centros para a consagração intelectual e artística, e para a renovação dos discursos estéticos e políticos no mundo hispano-falante, principalmente no México e na Argentina.

Nesta dissertação pretendemos observar as relações construídas por Arciniegas e os espaços letrados argentinos, entre 1939 e 1959, bem como o fluxo de ideias, a colaboração intelectual, e o contato entre os âmbitos intelectuais desses países intermediados por Germán Arciniegas.

Germán Arciniegas teve uma trajetória internacionalizada desde cedo. Já nos anos 1920, como líder dos estudantes colombianos que brigavam por mudanças no ensino universitário, vinculouse às redes do movimento de Reforma Universitária estabelecendo contatos epistolares com figuras representativas no México, no Perú e na Argentina ${ }^{9}$. Ainda na década de 1920, Arciniegas agiu como diretor da revista Universidad, onde foram discutidas algumas das tendências artísticas e ideológicas das vanguardas do continente, como as veiculadas nas revistas Amauta do Perú e Nosotros da Argentina ${ }^{10}$. Uma tendência já central para suas inquietações intelectuais: estabelecer pontes com os outros países da região, foi reforçada por seu desempenho como diretor e proprietário de Ediciones Colombia, onde imprimiu textos de alguns escritores latino-americanos.

Mas foi apenas na década de 1930 que o jovem "empresário cultural"11 se converteu em um escritor. Publicou sete livros entre 1932 e 1939: um estudo histórico sobre o papel dos estudantes da história da Europa e da América, dois livros de crônicas - que ele cultivava nas páginas de $E l$ Tiempo, jornal ao qual se vinculou já em 1918 -, um projeto de lei de reforma universitária - que apresentou como Representante à Câmara, quando eleito em 1932 -, um livro de ensaios de interpretação cultural da América - resultado, segundo seu testemunho, das aulas ministradas

\footnotetext{
${ }^{8}$ Miceli, Sergio. Vanguardas em retrocesso. São Paulo. Companhia das Letras. 2013.

${ }^{9}$ Bergel, Martín \& Martínez Mazzola Ricardo. "latinoamérica como práctica...” Op. Cit; Cacúa Prada, Antonio. Germán Arciniegas, su vida contada por él mismo. Bogotá. Universidad Central. 1991; Rivas Gamboa, Ángela. "Un estudiante-maestro". Historia Crítica. Bogotá. Uniandes. 2002.

${ }^{10}$ Medina, Álvaro. El arte colombiano en los años veinte y treinta. Bogotá. Colcultura. 1995.

${ }^{11}$ Arias Trujillo, Los leopardos. Una historia intelectual de los años veinte. Bogotá. Uniandes, 2013.
} 
desde 1925 na cátedra de sociologia da Faculdade de Direito na Universidade Nacional, em Bogotá -, e dois livros de história da Colômbia ${ }^{12}$.

A partir desse momento sua obra abriu o escopo para a reflexão sobre a história e a cultura numa escala continental. Nos anos 1940 e 1950 o escritor publicou um estudo sobre os alemães na conquista da Venezuela e da Colômbia, um estudo sobre o pedagogo chileno-venezuelano Andrés Bello, uma história do Caribe, duas coletâneas de ensaios de interpretação da história americana, uma biografia de Américo Vespuccio, uma crítica à política de todos os países da América Latina no pós-guerra, e um conjunto de 24 biografias de homens e mulheres latino-americanos. Essas obras foram publicadas no Chile, no México, mas, sobretudo na Argentina e nos Estados Unidos, países onde morou como diplomata e exilado, respectivamente. Além disso, Arciniegas se destacou como diretor de duas revistas de clara orientação continental: Revista de las Indias e Revista de América, a primeira uma empresa oficial do governo colombiano e a segunda uma publicação do jornal El Tiempo. Na década de 1940 Arciniegas assumiu por duas vezes como ministro de educação.

\section{A historiografia sobre Germán Arciniegas}

Os trabalhos publicados sobre a obra de Germán Arciniegas são muito variados, como ficou estabelecido a esse respeito nas bibliografias publicadas há mais de vinte anos por Juan Gustavo Cobo Borda ${ }^{13}$. Porém ver-se-á que a recente história intelectual e as novas práticas da crítica literária ainda têm um campo aberto para o desenvolvimento e o aprofundamento do conhecimento da obra e a trajetória de Arciniegas, e que os estudos sobre o autor começam uma interessante renovação.

Além das numerosas resenhas biográficas - e obituários-, é na crítica literária onde tem sido mais importante o estudo sobre Arciniegas: resenhas contemporâneas dos livros, algumas delas recolhidas em volume ${ }^{14}$, análises literárias sobre a sua ensaística ${ }^{15}$, e menções a seus trabalhos em

\footnotetext{
${ }^{12}$ Cacúa Prada, Antonio. Germán Arciniegas, su vida contada por él mismo. Bogotá. Universidad Central. 1991.

${ }^{13}$ Cobo Borda, Juan Gustavo, Germán Arciniegas. Cronología y Bibliografía. Bogotá. Planeta. 1990; Germán Arciniegas. 90 años escribiendo. Un intento de bibliografía. Bogotá. Planeta.1990.

${ }^{14}$ Cobo Borda, Juan Gustavo. (Comp.)Una visión de América. La obra de Germán Arciniegas desde la perspectiva de sus contemporáneos. Bogotá. Instituto Caro y Cuervo, 1990.
} 
análises da ensaística latino-americana em geral ${ }^{16}$. Também há algumas aproximações á sua escrita da história ${ }^{17}$. Outros textos onde é estudada a obra de Arciniegas são aqueles dedicados à invenção de rótulos idenitários como "América Latina" ou "Hispano-américa"18. Essas análises representam em conjunto um avanço para a superação dos marcos nacionais na discussão da obra do escritor.

Há também trabalhos mais focados na trajetória de Arciniegas em relação com os espaços sociais que a alicerçaram. Entre eles o estudo de José Moreno Villa ${ }^{19}$ sobre Arciniegas e Gabriela Mistral como protagonistas do desenvolvimento cultural em seus países; o de Juan Gustavo Cobo Borda $^{20}$ sobre as revistas que Arciniegas dirigiu; sobre o mesmo assunto contamos com um artigo do critico Jaques Gilard ${ }^{21}$ o de Eduardo Sáenz Rovner ${ }^{22}$ onde é considerado como um intelectual orgânico do stablishment colombiano; o de Ángela Rivas Gamboa ${ }^{23}$ que estuda a trajetória do escritor visando alguns espaços de sociabilidade intelectual até os anos 40, salientando seu papel como líder estudantil e professor de sociologia, e seu ingresso na política.

${ }^{15}$ Lagmánovich, David. 1978 Arciniegas: del relato al ensayo. Anales de literatura hispanoamericana, 6. 1981;Wills Robb, James. "Variedades del ensayismo en Alfonso Reyes y Germán Arciniegas" Thesaurus. Tomo XXXVI. Bogotá; Triviño Anzola, Consuelo. De Montaigne a Arciniegas: la escritura y la construcción del ser americano. Cuadernos Hispanoamericanos. No. 551-552, pp. 61-70

${ }^{16}$ Brown, Gerardo y Jassey, William. Introducción al ensayo hispanoamericano. Nueva York. Las Américas Publishing. 1968; Skirius, John. El ensayo hispanoamericano en el siglo XX. México. Fondo de Cultura 1981; Vitier, Medardo. Del ensayo americano. México. Fondo de Cultura Económica. 1945. Mead, Robert y Earle, Peter. Historia del ensayo hispanoamericano. México. Ediciones de Andrea. 1956

${ }^{17}$ Jaimes, Héctor. La reescritura de la historia en el ensayo hispanoamericano. Editorial Fundamentos. 2001; Fajardo, Alicia. "Historia de un ¿historiador?" Em: Boletín Cultural y Bibliográfico. Vol. XXV. No. 16. Bogotá. Banco de la República; Georgescu, Paul Alexandru. "Germán Arciniegas y la narración Histórica" En: Correo de los Andes. Bogotá. No. 46. 1987; Cobo Borda, Juuan Gustavo. Germán Arciniegas: La historia, esa otra forma de ficción. Revistas del Colegio Mayor de Nuestra Señora del Rosario. Bogotá. Vol. 83. No. 552, 1990, pp. 7-16. Textos dedicados à historia das formas de escrita da história na Colômbia, também têm refletido sobre a obra de Arciniegas. Betancout Mendieta, Alexander. Historia y nación. Tentativas de la escritura de la historia en Colombia. Medellín. La Carreta. 2007; Melo, Jorge Orlando. Historiografía colombiana: realidades y perspectivas. Medellín: Martín Vieco.

${ }^{18}$ Abellán, Luis. La Idea de América: origen y evolución. Madrid: Istmo. Martínez Blanco, Maria Teresa. Identidad cultural hispanoamericana. Europeísmo y originalidad americana. Madrid. Universidad Complutense. 1989. Georgescu, Paul. "Germán Arciniegas y el conocimiento múltiple de Hispanoamerica” En: Nueva visión sistemática de la narrativa hispanoamericana. Caracas. Monte Ávila Editores. 1989

${ }^{19}$ Moreno Villa, José. "Encuentros con Gabriela Mistral y Germán Arciniegas" En: Los autores como actores y otros intereses literarios de aquí y de allá. México. Fondo de Cultura Económica. 1951

${ }^{20}$ Cobo Borda, Juan Gustavo. "Las revistas de Arciniegas". En: La otra literatura latinoamericana. Bogotá: Procultura. 1982.

${ }^{21}$ Gilard, Jaques. "Las revistas de Arciniegas: la inteligência y el poder". En: Renaud, Maryse. En torno a Germán Arciniegas. Poitiers: Centre de Recherches Latino-americaines. U. de Poitiers, 2002.

${ }^{22}$ Sáenz Rovner, Eduardo. Germán Arciniegas: entre la libertad y el establecimiento. Historia Crítica, No. 21. Bogotá. Universidad de los Andes. 2001

${ }^{23}$ Rivas Gamboa, Ángela. Un estudiante maestro. Historia Crítica, No. 21. Bogotá. Universidad de los Andes. 2001 Espagne, Michel, ’Du creuset...”. Op. Cit. 
Nos artigos de Sáenz Rovner e Rivas Gamboa, que lançam mão de conceitos próprios da história intelectual como intelectual orgânico e sociabilidade, constrói-se uma interpretação do papel de Arciniegas num contexto exclusivamente colombiano. Ricardo Arias ${ }^{24}$ em seu estudo sobre os jovens intelectuais católicos colombianos da década de 1920, faz inúmeras menções a Arciniegas, a quem considera um "empresário cultural", discutindo em contexto as posições da geração à qual o escritor pertencia, em relação com a educação e os direitos da mulher, a reforma universitária, e os partidos políticos.

Sobre a questão dos contatos do escritor colombiano com campos intelectuais de outros países, têm recebido atenção as relações de Germán Arciniegas com alguns intelectuais mexicanos, em especial sua correspondência e parceria com o poeta Carlos Pellicer, nascida das iniciativas de José Vasconcelos no começo dos anos $1920^{25}$, e a relação epistolar e colaboração intelectual com Alfonso Reyes e com Germán Pardo García, colombiano radicado no México ${ }^{26}$. Também foi salientada sua vinculação ao projeto de interpretação cultural da historia da América articulado na iniciativa editorial Tierra Firme, do Fondo de Cultura Económica. Também se pode fazer menção ao estudo da correspondência do escritor com Gabriela Mistral ${ }^{27}$.

No que tem a ver com o campo intelectual norte-americano, já foi apontado que várias obras do autor foram traduzidas para o inglês, que o escritor foi professor e difusor da literatura e a historia latino-americana nos anos 40 e 50, além de animador da defesa dos princípios liberais. Pelo menos alguns trabalhos sobre o sentido dos Latin American Studies identificam Arciniegas como uma figura de destaque no processo de construção do conhecimento sobre América Latina nos Estados Unidos ${ }^{28}$. Outro aspecto importante da dimensão internacional da trajetória de Arciniegas é a sua participação na chamada "guerra fria cultural" nos anos 50 y 60, como membro do

\footnotetext{
${ }^{24}$ Los leopardos... Op. Cit.

${ }^{25}$ Zaitzeff, Sergei. "El joven Arciniegas a través de su correspondencia con Carlos Pellicer. Historia Crítica, No. 21, 2001, p. 71-75; Bergel, Martín \& Martínez Mazzola "Latinoamérica como práctica...” Op. Cit.

${ }^{26}$ Willis Robb, James, "Imágenes de América en Alfonso Reyes y en Germán Arciniegas", Humanitas, Monterrey, 1964, págs. 255-269; "Alfonso Reyes y Germán Arciniegas: corresponsales e hispanoamericanistas afines". Thesaurus. Tomo XXXVIII. Bogotá, 1983. A correspondencia que dá embasamento a esses estudos já foram publicadas, como se indica na seção relativa às fontes dessa introdução.

${ }^{27}$ Zaitzeff, Sergei. Germán Arciniegas y Gabriela Mistra: contatos epistolares. Anthropos. No. 234, 2014.

${ }^{28}$ Bethell, Leslie. O Brasil e a idéia de "América Latina" em prespectiva histórica. Estudos históricos Vol. 22. No. 44. Rio de Janeiro. 2009
} 
Congresso pela Liberdade da Cultura e diretor da revista Cuadernos, seu órgão em espanhol, a partir de $1959^{29}$.

De sua relação com a Argentina quase sempre é sublinhado nos esboços biográficos, a começar pelos depoimentos autobiográficos do próprio escritor, a participação de Arciniegas nos debates da revista Sur nos anos 40 y 50, e nos jornais La Prensa e La Nación. Também têm sido abordadas as relações entre Arciniegas e Macedonio Fernandez ${ }^{30}$. Um aspecto de muito interesse são as condições e projeções das relações intelectuais construídas pelo escritor e os escritores do circuito argentino, ou com as editoriais Losada e Sudamericana, e que não conta ainda com estudos. No trabalho que ora apresentamos agora queremos dar uma contribuição para essa dimensão da trajetória do escritor, através do exame, principalmente, da correspondência ${ }^{31}$.

Outro campo aberto para os pesquisadores na trajetória e a obra do escritor que pretendemos aproveitar nesta dissertação é a sua produção jornalística, em especial os artigos que descrevem relatos e impressões de viagens. Focaremos os artigos relativos à Argentina, mas queremos mencionar que existe um conjunto importante de textos desse tipo que permanecem inéditos, com exceção dos relativos ao Paraguai, de recente edição ${ }^{32}$.

Vale a pena mencionar um estudo que contempla a correspondência do escritor, disponível na Biblioteca Nacional da Colômbia. Trata-se da tese de graduação de Carlos Arbeláez ${ }^{33}$ e constitui um esforço por abordar esse enorme volume de cartas que oferece sem dúvida, um dois principais filões de análise para uma renovação dos estudos sobre o autor numa perspectiva da história intelectual, que pretendemos desenvolver aqui.

\footnotetext{
${ }^{29}$ Saenz Rovner, Eduardo. Germán Arciniegas entre la libertad.... Op. Cit. Glondys, Olga. La guerra fría cultural y el exilio republicano español. Madrid. CSIC. 2012. Marta Ruiz Galvete, "Cuadernos del Congreso por la Libertad de la Cultura : anticomunismo y guerra fría en América Latina “, El Argonauta español [En ligne], 3 | 2006, consultado 11/09/2013. URL : http://argonauta.revues.org/1095. Jannello, Karina. "Los intelectuales de la Guerra Fría. Una cartografía latinoamericana (1953-1962). Políticas de la memoria. No. 14. 2013-2014. Buenos Aires. pp. 79-101.

${ }^{30}$ Tamayo, Martha Lúcia. Germán Arciniegas y Macedonio Fernández, vidas paralelas posmodernas. Bogotá. Universidad Javeriana. 2006. O texto inclui a reprodução de uma série de cartas trocadas entre ambos os escritores.

${ }^{31}$ Outros espaços interessantes de serem pesquisados para observar as rotas e fluxos dos intercâmbios intelectuais, são o chileno, especialmente a relação do escritor com a indústria editorial (Zig-Zag, Ercilla) onde publicou nas décadas de 1930, 40 e 50; e os campos costarriquense, uruguaio ou venezuelano, onde revistas e jornais reproduziram seus artigos.

${ }^{32}$ Estampas del Paraguay. Bogotá: Uniandes, 2015.

${ }^{33}$ Um proyecto americanista por correspondência. Tese de graduação em sociologia. Bogotá, Universidad Javeriana, 2014.
} 


\section{Mediações e mediadores culturais.}

As noções de mediação cultural e de mediadores culturais nos pareceram sugestivas para pensarmos o desempenho de Arciniegas como intelectual em meio aos espaços letrados dos dois países $^{34}$. Segundo Michel Espagne ${ }^{35}$, mediadores são os agentes intermediários entre dois ou mais espaços de produção de bens culturais. A intermediação exercida, a mediação cultural, implica o movimento de pessoas, objetos, linguagens, ideias, palavras, teorias, discursos, conceitos, etc., do lugar onde são produzidos até outro onde são acolhidos e assimilados em meio a determinadas adaptações ${ }^{36}$.

A preocupação pelas mediações não se concentra tanto no fato de existir uma "importação" de algum aspecto da cultura alheia, mas nos compromissos que implica sua introdução, as estratégias que a motivam e as rejeições que provoca, salientando o papel dos agentes ${ }^{37}$. A mediação cultural é assim uma superação da ideia de "influência" na medida em que existe uma preocupação por observar e analisar de perto os agentes, a materialidade, as estratégias e os sentidos daquilo que transita de um lugar a outro ${ }^{38}$. Assim, os estudos sobre os mediadores e as mediações culturais focam na análise dos suportes, estratégias e lógicas desse trânsito ${ }^{39}$.

A mediação supõe sempre uma transformação daquilo que é trasladado, em função das conjunturas dinâmicas do contexto sociocultural ao qual é transportado. São as condições específicas desse contexto (dinâmicas de poder internas, necessidades de diferentes ordens) que operam a seleção, o desface ou os "mal-entendidos" costumeiramente associados às recepções de

\footnotetext{
${ }^{34}$ É importante salientar que a noção de mediação tem estimulado análises nos mais diversos contextos históricos, da antiguidade à história moderna. Ainda mais, as mediações culturais podem ocorrer entre "culturas" ou espaços de produção cultural não apenas internacionais mas também dentro das nações, por exemplo, entre registros eruditos e populares, indígenas e mestiços. etc.

${ }^{35}$ Espagne, Michel. "Du creuset espagnol à lEspagne hors les murs". Mélanges de la Casa de Velásquez . 2008. Consultado o 15/11/2013. URL: http://mcv.revues.org/775.

${ }^{36}$ Noiriel, Gerard, Espagne, Michel. "Tranferts culturels: léxemple franco-allemand. Entretien avec Michel Espagne. Em: Genèses, 8, 1992. pp. 149A mediação cultural é, segundo Espagne (2008), um processo de circulação de bens culturais que não se limita ao simples deslocamento dos bens, mas que envolve uma apropriação, uma recriação em tanto transformação semântica.

${ }^{37}$ Joyeux, Beatriz. "Les tranferts culturels. Un discours de la méthode. Hyphothèses. 2002/1. pp. 151.

${ }^{38}$ A superação da noção de influencia a favor de uma história social e cultural das formações ideológicas na América Latina tem sido ressaltada por Laperière (2007).

${ }^{39}$ Botrel, Jean François. "Cosmopolitismo e mediación cultural em la España del siglo XIX". Península, Revista de Estudios Ibéricos. No. 4, 2007, pp. 35.
} 
bens culturais estrangeiros ${ }^{40}$. Dessa maneira, o estudo das mediações e os mediadores não apenas se ocupa de constatar as incorporações de elementos alheios e de identificar o sentido de suas recepções, mas de explicá-las atendendo ao contexto sociocultural dos sujeitos que as agenciam. A análise opera também na direção contrária: a ressignificação dos bens culturais "importados" pode iluminar a compreensão do contexto onde são acolhidos e transformados ${ }^{41}$

Uma hipótese corrente entre os pesquisadores é que a seleção dos elementos introduzidos é mobilizada para fortalecer determinadas posições e pontos de vista nas dinâmicas próprias do destino da mediação. Para Fréderic Martínez ${ }^{42}$, por exemplo, “la relación con el exterior sólo se vuelve comprensible cuando se le aborda desde um marco histórico nacional y en función de las lógicas nacionales", de maneira que durante o século XIX, na Colômbia apenas "el estudio de los conflitos políticos explica la referencia europea en un momento dado". De maneira semelhante, Pierre Bourdieu tem apontado que "los textos circulan sin su contexto", no circuito internacional das ideias, e nessa circulação ressaltam as reinterpretações e deturpações decorrentes da estrutura do campo onde são introduzidos. Na transferência de um campo a outro as ideias passam por um conjunto de operações de seleção e marcação que norteiam sua função no novo espaço. Uma determinada instrumentalização seria possível como expressão da existência de certas afinidades eletivas entre os produtores e os importadores dos bens que são objeto da transferência; afinidades que seriam resultado das respectivas posições em seus campos, assim como de homologias de interesses, estilos e projetos intelectuais que favoreceriam a criação de "alianças" com o objetivo de alicerçar posições marginais ou ameaçadas ${ }^{43}$.

Além dessas afinidades, um dos problemas mais interessantes das mediações culturais diz respeito à sua relação com as conjunturas políticas, os momentos de aproximação e choque entre os governos ${ }^{44}$. O problema é importante porque coloca em foco a relação entre o Estado e as mediações culturais, o que se desdobra em considerações sobre as condições institucionais dos

\footnotetext{
${ }^{40}$ Jojeux...Op. Cit. 153. Bourdieu, Pierre. "Las condiciones sociales de la circulación internacional de las ideas". En: Intelectuales, política y poder. Buenos Aires, Eudeba, 2000.

${ }^{41}$ Noiriel \&Espagne...Op. Cit.

${ }^{42}$ El nacionalismo cosmopolita. Bogotá. Banco de la República. 1997.

${ }^{43}$ Bourdieu...Op. Cit.

${ }^{44}$ Noiriel \& Espagne Op. Cit. pp. 149.
} 
agentes, os sentidos oficiais dos discursos difundidos e das seleções efetuadas sobre os bens culturais em trânsito.

Destarte, além do problema central das "reinterpretações em cadeia", Michel Espagne ${ }^{45}$ enfatiza a importância de uma "sociologia dos mediadores", do estudo histórico dos "vetores" da mediação. O autor repara na importância de explorar as caraterísticas e condições dos agentes, que podem ser grupos ou indivíduos, conscientes ou não da mediação que estão exercendo, como viajantes, diplomatas, tradutores, redes de correspondência, professores etc. Da mesma maneira, salienta a relevância de explicitar e analisar os mecanismos dessa intermediação, seus suportes materiais: os livros, as pinturas, as cartas.

\section{Proposta de análise}

Levando em conta essas considerações, no curso da pesquisa decidimos testar a utilidade dessas noções para compreender os vínculos de Arciniegas com o mundo argentino entre 1939 e 1960, suas projeções sobre a obra e a trajetória do próprio escritor e sobre as relações entre os círculos de escritores e artistas colombianos e argentinos. Optamos por fazer uma análise focada em um agente "individual" embora privilegiado dos intercâmbios culturais que animaram a vida intelectual do continente na primeira metade do século XX. Essa escolha implicou deixar de lado a análise da eficácia das mediações culturais entre Argentina e Colômbia, tendo em vista que escapa às possibilidades dessa pesquisa avaliar, por exemplo, até onde as perspectivas literárias, ideológicas ou artísticas desenvolvidas no circuito portenho - e que o escritor colombiano quis comunicar no âmbito de seu país -, foram efetivamente assimiladas e adaptadas pela comunidade intelectual e artística colombiana. Mas a escolha tem também benefícios. Um deles é a possibilidade de explorar com maior profundidade, no tempo disponível, um acervo documental extenso. Outra, não menos importante, a possibilidade de melhor explorar as condições sociais de um conjunto de iniciativas de intercâmbio cultural.

Preferimos enfocar três dimensões a atividade de Arciniegas: enquanto diplomata, escritor em relação com o campo editorial, e autor de relatos de viagem. Cada uma delas sugere condições

\footnotetext{
${ }^{45}$ Espagne, Michel, "Du creuset...". Op. Cit.
} 
sociais diferentes para estabelecer variados tipos de arranjo com os âmbitos letrados, e implicam possíveis intercâmbios entre eles, em planos diversos.

Estabelecemos quatro ordens de questões para elucidarmos essas relações e iniciativas:

A) O conteúdo das mediações: quais os elementos da tradição cultural e política colombiana, da produção literária e artística do país, que Arciniegas quis fazer conhecer do público argentino? O quê da tradição e da produção argentina quis levar à Colômbia? Que representações da história e da sociedade desses países ele veiculou?

B) Seus mecanismos e estratégias: que suportes empregou em suas empreitadas: troca de correspondência, redação de artigos de jornal, publicação de ensaios, alocução de conferências, realização de exposições de livros ou artísticas, instalação de monumentos?

C) As condições sociais e culturais de possibilidade para seu planejamento e realização: qual o papel do Estado, em especial da diplomacia e do mecenato oficial, nas atividades de Arciniegas? Que tipo de afinidades explicam os vínculos do escritor com os espaços intelectuais com os quais estabeleceu colaborações na Argentina, e quais foram esses espaços de sociabilidade? Que projetos culturais compartilharam?

D) E, finalmente, o lugar que essas iniciativas tiveram na trajetória e na obra do escritor: qual o papel que desempenharam seus vínculos com a Argentina no curso da carreira do escritor para a circulação de sua obra e sua consagração como intelectual, para o fortalecimento de suas empresas culturais na Colômbia?

\section{Fontes.}

Além de escritor prolífico, Arciniegas foi um correspondente muito ativo desde o começo da sua atividade na década de 1920. Fragmentos de sua correspondência foram publicados já desde a década de 1980. Juan Gustavo Cobo Borda coletou dois volumes com cartas trocadas entre o escritor e diferentes escritores do mundo ${ }^{46}$; Roberto Esquenazi Mayo editou as cartas trocadas entre ele e Arciniegas ${ }^{47}$; e Sergei Zaitzeff editou e comentou a correspondência com os

\footnotetext{
${ }^{46}$ Cobo Borda, Juan Gustavo (Comp.) Arciniegas de cuerpo entero. Bogotá. Planeta. 1987; Arciniegas corresponsal del mundo 1928-1989. Bogotá. Fundación Santillana para Iberoamérica. 1990

47 Esquenazi Mayo, Roberto. Experiencias de toda una vida: Cartas de Germán Arciniegas. Universidad de Colorado. Departamento de Español. 1997
} 
mexicanos Alfonso Reyes y Carlos Pellicer ${ }^{48}$, assim como as intercambiadas entre Reyes, Gabriela Mistral, Arciniegas e Germán Pardo García, poeta colombiano radicado no México ${ }^{49}$. Recentemente foram publicadas as cartas remetidas a Arciniegas pela pintora colombiana Emma Reyes $^{50}$.

Mas é na Biblioteca Nacional da Colômbia, em Bogotá, onde se encontra um acervo muito maior de cartas conservadas pelo autor e doadas a essa instituição em 1976. O arquivo é formado por um conjunto de 29 caixas - compostas até por 30 pastas cada -, das quais as duas primeiras (1 e 2) conservam, em ordem cronológica, copias das missivas remetidas por Arciniegas entre $1933 \mathrm{e}$ 1968; enquanto as quatro seguintes $(3,4,5$, e 6$)$ contêm as cartas redigidas pelo escritor-diplomata durante o período 1959-1962, no qual exerceu o cargo de embaixador na Itália. A correspondência recebida pelo autor, e organizada em pastas separadas para cada remetente, ocupam a maior parte da coleção: treze caixas (17-29). O restante do arquivo é composto por textos originais, alguns inéditos, de Arciniegas (7 e 8) ou de outros autores (9, 10, 11 e 12). Nesta dissertação consultamos as caixas 1 e 2 e as pastas (25) relativas a autores e instituições vinculados com a vida argentina das caixas 17-29.

O uso da correspondência como fonte para analise histórica merece alguns comentários. Recentemente, na América Latina, os estudos sobre as comunidades intelectuais e a história política tem se debruçado sobre as chamadas "fontes privadas", como cartas e diários. O olhar sobre esse tipo de fonte foi renovado ao mesmo tempo em que a historiografia retomava a política e a biografia como campo de reflexão e estudo, e mais recentemente com o crescimento da história dos intelectuais. Mas o interesse pelas cartas como fonte ultrapassou o limite das elites culturais, como seriam os intelectuais e as grandes figuras da política - para cujas reconstruções biográficas o uso da correspondência não é nenhuma novidade -, e atingiu aos pesquisadores das culturas populares, muitas vezes analfabeto, reconhecendo as estratégias de participação desses sectores no universo letrado.

\footnotetext{
48 ZAITSEFF, Sergei (Comp.) Algo más de la experiencia americana. Correspondencia entre Alfonso Reyes y Germán Arciniegas. México. El Colegio Nacional. 1998; Correspondencia entre Carlos Pellicer y Germán Arciniegas, 1920-1974. México. Consejo Nacional para la Cultura y las Artes/ Herederos de Germán Arciniegas. 2002.

${ }^{49}$ México es cosa mía. Reyes, Mistral Arciniegas: epistolário de Germán Pardo García. México: El Colegio Nacional, 2011.

${ }^{50}$ Reyes, Emma. Memorias por correspondência. Bogotá: Laguna Libros, 2012.
} 
As questões levantadas sobre as cartas foram também reatualizadas. Reflete-se sobre a correspondência em si, sobre os gêneros epistolares, os estilos, tons e usos da linguagem veiculados nas missivas.

Nesse sentido resulta interessante mencionar que o acervo consultado agora representa uma correspondência profissional onde as matérias mais tratadas são questões relativas à carreira literária (edição de livros e revistas, participação e organização de congressos e cursos universitários), e às funções diplomáticas e ministeriais. Assuntos comerciais encontrados, fora os relativos à edição de livros, foram escassos. Informações sobre a vida familiar apareceram, mas pouco, em meio a questões profissionais nas cartas trocadas entre Arciniegas e seus amigos mais próximos, pois estão totalmente ausentes as cartas encaminhadas à família, seja à esposa Gabriela e suas duas filhas, aos irmãos ou à mãe, dos quais tampouco há uma pasta nas caixas da correspondência recebida. Em consequência do caráter profissional do acervo doado pelo autor, a maior parte das cartas redigidas e conservadas por ele foi escrita a máquina. Em raras exceções essas cartas superavam as três folhas.

As cartas oferecem à história intelectual usos os mais variados. As fontes privadas contribuem com a elucidação do caráter coletivo da atividade intelectual. Assim seria possível a reconstrução das redes de intercâmbio, a construção de uma cartografia das trocas de correspondência que leve em conta os ritmos dos intercâmbios; também o reconhecimento de relações de parceria entre atores que poderiam ser considerados distantes a partir das divisões no campo literário, projetadas pelas divergências estilísticas, metodológicas e inclusive teóricas, sob as quais jaz a colaboração, o respeito e até a amizade ${ }^{51}$. Informam também sobre os processos de construção e edição das obras em relação com as exigências editoriais e as próprias preferencias do escritor em matéria de formatos de impressão, ou ainda de cores e imagens nas capas dos livros. As cartas podem informar também sobre a consagração do escritor no mercado: a ampliação da circulação de seus textos, a presença de agentes que distribuem em jornais, revistas e editoras os textos do escritor, ou então o encaminhamento de resenhas de seus livros para determinados jornais e revistas ${ }^{52}$. Por fim, as cartas oferecem uma janela à trajetória pela qual é possível ver os fatores envolvidos

\footnotetext{
${ }^{51}$ Martins Venancio, Giselle. "Cartas de Lobato a Viana. Uma memória epistolar silenciada pela história". Em: Castro Gomes, Ângela de (org.). Escrita de si. Escrita da história...Op. Cit. pp.111-137.

52 Como assinala Castro Gomes, "um espaço preferencial para a construção de redes e vínculos que possibilitam a conquista e a manutenção de posições sociais, profissionais e afetivas”. Ibíd, p. 21.
} 
nas eleições tomadas pelo escritor sobre a própria carreira: assumir e deixar cargos, eleger o vínculo com diferentes editoras ou universidades, em particular a relação com os cargos oficiais.

Pode observar-se a pluralidade dos usos das cartas: aquelas destinadas a serem publicadas como formas de apoio ou de oposição a uma causa em meios como jornais ou revistas; cartas para discutir assuntos propriamente intelectuais: comentários de livros, planejamento de empresas comuns como revistas, congressos, associações; cartas para pedir ou oferecer recursos econômicos para as atividades intelectuais ${ }^{53}$.

A correspondência permite enxergar a diversidade das relações estabelecidas entre escritores, editores, diretores de revistas, professores etc., sem menosprezar as relativas ao dinheiro, considerado geralmente alheio à atividade literária. Pode-se abordar o problema do sustento econômico da personagem estudada, e o da origem dos recursos que viabilizam as atividades intelectuais: assim contamos no acervo de Arciniegas com cartas trocadas pelo autor e diferentes fundações, jornais, revistas, mecenas, ministérios e universidades tratando de honorários, salários, vendas, patrocínios. O estudo desse tipo de fontes contribui para definir melhor a complexidade das relações entre os agentes do mundo intelectual ponderando a importância de suas dimensões comerciais, pessoais, ideológicas etc. Mas, além disso, permitem determinar mais amplamente o conjunto de instâncias que intervêm na produção de uma obra ou uma carreira literária.

A correspondência tem sido usada por pesquisadores para dar conta das relações políticas e intelectuais transnacionais construídas pelos escritores latino-americanos ${ }^{54}$. Podemos fazer menção do trabalho da crítica Patricia Artundo $^{55}$ sobre as relações do brasileiro Mário de Andrade com artistas e escritores argentinos, e os trabalhos de Sergei Zaitzeff sobre a correspondência entre Alfonso Reyes e Genaro Estrada a respeito de França e Brasil ${ }^{56}$. Na

\footnotetext{
${ }^{53}$ A correspondência como uma forma de sociabilidade intelectual foi por Bergel \& Martínez, "Latinoamerica como práctica...". Op. Cit. Segundo Angela de Castro Gomes, "a correspondência é lugar de sociabilidade: é lugar de troca de ideias, de construção de projetos, de amores e de ódios e pro fim, mas não em ultimo lugar, de pedir emprego, porque intelectual geralmente é pobre, mas é ambicioso". Castro Gomes, Ângela. "Nas malhas do feitiço: o historiador e os encantos dos arquivos privados". Estudos Históricos. No. 21, 1998,p. 124.

54 "Dossier: La correspondência en la historia política e intelectual latinoamericana." Politicas de la memoria. No. 15. Buenos Aires. 2014-2015.

${ }_{55}^{55}$ Mario de Andrade e a Argentina. Um pais e sua produção cultural como campo de reflexão. São Paulo: Edusp. 56 "Alfonso Reyes en París através de su correspondencia con Gerano Estrada".NRFH, No. 37; "Alfonso Reyes en Brasil através de su correspondencia con Genaro Estrada". Anueario brasileño de estudios hispánicos, No.4. 1994.
} 
historiografia colombiana, podemos mencionar o estudo de Gonzalo Cataño sobre Luis Eduardo Nieto Arteta, baseado no estudo do arquivo pessoal do escritor barranquillero, e que contém reflexões sobre suas experiências diplomáticas e intelectuales em Madrid e Buenos Aires nas décadas de 1930 e $1940^{57}$.

As fontes privadas como as cartas acarretam também riscos e armadilhas para o pesquisador. A mais advertida nas discussões metodológicas é a da suposta verdade íntima que o leitor poderia encontrar, pois num texto de produção, circulação e leitura privada, ainda íntima, os atores poderiam se expressar com completa liberdade a respeito de motivações, opiniões e posicionamentos. Longe disso, diferentes estudos atentam para o fato de a escrita privada estar codificada, pautada por regras do gênero epistolar ${ }^{58}$; e de representar um espaço de configuração da identidade, de afirmação e de exposição de si.

A construção de um arquivo pessoal guardando as cartas recebidas e redigidas por Arciniegas, é expressão de um "desejo de monumentalização"59 que se consuma no ato da doação, e que constitui uma forma da auto representação evidente pela seleção do tipo de correspondência que compõe o acervo. Queremos mencionar algumas inquietações a esse respeito com as quais tivemos que lidar. Primeiro, a documentação doada pelo autor, de teor profissional, já estabelece uma pauta de leitura sobre o personagem, interessado na construção e na promoção de uma representação de si como escritor e divulgador da cultura americana e colombiana. Nessa representação reside um sentido de distinção muito claro entre sua vida pública e sua vida privada transparece no conjunto documental doado, no qual a segunda dimensão inexiste praticamente.

Por outro lado, a própria constituição de um arquivo pessoal implica um processo de memória condicente com a individualização da experiência histórica, da formação de um registro estável e permanente e linear - apesar de múltiplo - do "eu"60, que contribui para o processo de subjetivação da pessoa e que aproxima o ato de "arquivar a própria vida" de um projeto

\footnotetext{
${ }^{57}$ Cataño, Gonzalo. La introducción del pensamiento moderno en Colombia. El caso de Luis E. Nieto Arteta. Bogotá. Universidad Externado de Colombia. 2013.

${ }^{58}$ Prochasson, Christophe. “Atenção: verdade! Arquivos privados e renovação das práticas historiográficas”. Estudos Históricos. No, 21, 1998, pp. 105-119.

${ }^{59}$ Fraiz, Pricilla. “A Dimenssão autobiográfica dos arquivos pessoais”. Estudos Históricos. No, 21, 1998, pp.55;87

${ }^{60}$ Castro Gomes, Ângela de. "Escrita de si, escrita da Historia: a título de prologo". Em: Castro Gomes, Ângela de (org.). Escrita de si, escrita da historia. Rio de Janeiro, FGV, 2004.
} 
autobiográfico $^{61}$. O acervo de Arciniegas expressa bem essa função do arquivo pessoal: Além das cartas recebidas por Arciniegas, o colombiano guardou também cópias das redigidas por ele. Fundamentalmente um acervo desse tipo contempla a apropriação de uma variedade de fragmentos de discursos e de histórias alheias, fazendo uma coleção documental que é preciso "desindividualizar" atentando para uma representação mais coletiva do que individual da vida e da produção intelectual ${ }^{62}$.

Outras fontes como os artigos de jornal apresentam dificuldades de outra ordem. Dispondo de um catálogo, embora incompleto, que contempla boa parte dos artigos do escritor redigidos no curso de 80 anos, conseguimos nos orientar num mar de temas abordados pelo escritor nessa oficina que foi para ele, acreditamos, a escrita jornalística. Escolhemos um conjunto de 34 artigos publicados no jornal El Tiempo entre 1940 e 1959, nos quais abordou temas referidos à Argentina. Artigos de revistas culturais e os próprios livros publicados por Germán Arciniegas constituem também o acervo estudado, embora sua relevância para a análise seja menor enquanto à novidade do estudo.

\section{Organização da dissertação}

A dissertação está organizada em duas partes. Na Parte I analisamos as atividades do escritor durante sua temporada de vida na Argentina como diplomata entre 1939 e 1941. Focamos no capítulo 1 as relações entre as atividades oficiais e sua condição de escritor e no segundo capítulo, debruçamo-nos sobre as atividades desenvolvidas pelo escritor nesses anos, discutindo a pertinência de noções como diplomacia cultural e mediações para compreender essas gestões.

Na Parte II, conformada pelos capítulos 3 e 4, estendemos o período de 1939 até 1959. Focamos nas relações construídas pelo escritor com a cultura argentina numa temporalidade maior do que a da sua missão diplomática em Buenos Aires. No capítulo 3 vemos seu vínculo com as editoras portenhas, sua importância para a sua própria trajetória e os cruzamentos entre os projetos

\footnotetext{
${ }^{61}$ Fraiz, Pricilla. “A Dimenssão autobiográfica...”. Op. Cit.

${ }^{62}$ Palmeira, Miguel. Arquivos pessoais e história da história: a propósito dos Finley Papers. Em: I. Travancas; J. Rouchou; L. Heymann. (Org.). Arquivos pessoais: reflexões multidisciplinares e experiências de pesquisa. Rio de Janeiro: FGV, 2014, p. 79-99.
} 
intelectuais do escritor e os editores, visando compreender as dimensões ideológicas e comerciais que atravessaram essa associação e deram sentido aos intercâmbios veiculados através dela. No capítulo 4 concentramo-nos nas representações da nação argentina, que Arciniegas transmitiu em seus artigos de jornal para o público colombiano, prestando atenção aos diálogos implícitos com as tradições de interpretação cultural desenvolvidas pelos escritores argentinos. Interessa observar como Arciniegas selecionava e filtrava pelo prisma da sua própria reflexão um conjunto de representações sobre a nacionalidade, a tradição cultural e o progresso material, que haviam sido desenvolvidas pelos pensadores argentinos nas décadas anteriores ao desembarque de Arciniegas em Buenos Aires. 


\section{PRIMEIRA PARTE}

\section{Germán Arciniegas diplomata e intelectual na Argentina, 1939-1941.}

\section{Introdução}

Germán Arciniegas exerceu a função de diplomata na Argentina entre 1939 e 1941 e durante sua temporada de vida em Buenos Aires estabeleceu uma relação entre as funções diplomáticas a mediação cultural. A posição oficial do cargo que levou o escritor até a capital argentina colocouo em condição privilegiada para a mediação, embora essa não seja suficiente para explicar as caraterísticas que ele lhe deu. Para tal propósito, o capítulo baseia-se no estudo das correspondências do escritor e na contextualização pertinente da história das relações diplomáticas colombiano-argentinas. A importância da condição diplomática é salientada por mais uma consideração: durante a primeira metade do século $\mathrm{XX}$, diferentes expressões do "americanismo" no plano intelectual estiveram alicerçadas em projetos políticos e, de fato, boa parte dos intercâmbios intelectuais e da circulação de artistas e escritores pelos países da região deu-se através de canais diplomáticos. Na primeira parte do capítulo, mostraremos as afinidades entre os trabalhos diplomático e intelectual e, na segunda, analisaremos as funções propriamente diplomáticas desenvolvidas por Arciniegas.

No conteúdo do capítulo, além de analisar a forma em que o trabalho diplomático e as atividades intelectuais de Arciniegas estiveram atreladas, como é, por exemplo, o caso do monitoramento sobre a imprensa portenha, se pretende mostrar como a posição de Arciniegas como diplomata na Argentina condicionou suas atividades intelectuais, e como essas condicionaram sua gestão diplomática, para favorecê-las ou não.

É necessário esclarecermos uma distinção entre as atividades diplomáticas e as mediação para compreender o desempenho de Arciniegas. Seria possível pensar que boa parte das atividades realizadas por Arciniegas a favor do intercâmbio cultural entre a Argentina e a Colômbia entre 1939 e 1941, foram expressões da chamada "diplomacia das letras" ou ainda, de maneira mais abrangente, de uma possível "diplomacia cultural", no sentido de obedecer a um plano estabelecido desde os ministérios para expor uma determinada imagem do país no estrangeiro, ou 
incentivar as trocas entre comunidades letradas ou científicas de maneira contínua. Mas fora dos espaços oficiais, sem a existência de uma orientação diplomática desse tipo, a mediação cultural pôde acontecer pela iniciativa particular, a través de instituições privadas ou mesmo de alguns personagens $^{63}$. É possível pensar no interesse de Arciniegas, além das atividades diplomáticas e das iniciativas que tinham um caráter oficial, querendo estimular o fluxo e a articulação entre revistas e projetos editoriais de ambos os países; e de oferecer aos públicos colombiano e argentino versões da história e da cultura alheia por meio da própria ensaística. O alcance dos vínculos criados pelo escritor com vários âmbitos do campo intelectual portenho superou o plano diplomático.

Destarte, suas atividades como diplomata adquiriram outra dimensão e aparecem como passos iniciais de um processo de intercâmbios e articulações, ou seja, de mediação cultural, que Arciniegas impulsionou durante décadas entre os espaços artísticos e intelectuais desses países; e que nem sempre os adidos culturais estiveram interessados em estimular, nem foram bem sucedidos na empreitada.

${ }^{63}$ Dumont-Quessard, Juliette. De la coopération intellectuelle à la diplomatie culturelle. Les voies/x de l'Argentine, du Bresil et du Chili (1919-1946). Tese de doutorado. Université Sorbonne Nouvelle-Paris 3. 2013. 


\section{Capítulo 1. Afinidades entre os trabalhos de escritor e diplomata.}

\section{O duplo prestígio}

Arciniegas chegou a Buenos Aires em dezembro de 1939, como Ministro Conselheiro da embaixada da Colômbia na Argentina. $\mathrm{O}$ chefe da missão era o político conservador ${ }^{64}$ Roberto Urdaneta Arbeláez (1890-1972), que mais tarde seria presidente da República. No período de 1939 a 1941, o jornalista Germán Arciniegas (1900-1999) assumiu pela primeira vez o rol do escritor-diplomata, que depois encarnou por muitos anos, já sendo um escritor consagrado, entre 1959 e 1977. Seu primeiro emprego numa missão no exterior - secretário do Cônsul Geral em Londres - teve lugar entre 1930 e $1932^{65}$, mas nesse momento sua carreira como escritor ainda não tinha dado o passo definitivo para a publicação de seu primeiro livro, o que só aconteceu depois do regresso de Arciniegas à Colômbia. Com efeito, em 1932 apareceu El estudiante de la mesa redonda, escrito, segundo o seu próprio testemunho, durante a estadia de dois anos na capital inglesa ${ }^{66}$. Assim, pode-se registrar um dado eloquente na trajetória do escritor: tanto a carreira diplomática quanto a de escritor tiveram um começo simultâneo e solidário.

Durante os anos em que viveu na Inglaterra, Arciniegas não teve um contato significativo com o mundo intelectual, daí que sua posição e sua atitude foram as de observador, ou, como ele gostava de dizer, as de "estudante", principalmente atento à organização das instituições universitárias e aos espetáculos da "alta cultura". Seu trabalho tampouco representou uma grande

\footnotetext{
${ }^{64}$ Filiado ao Partido Conservador que ocupou o poder entre 1885 e 1930. Em meio a discussões internas ao partido, Urdaneta defendia a colaboração no governo de membros do Partido Liberal já na década de 1920, e tomou parte nos governos liberais a partir de 1930.

${ }^{65}$ O Partido Liberal, ao qual pertenceu Arciniegas, chegou ao poder em 1930, depois de 45 anos. Nos quinze anos de "República Liberal", até 1946, Arciniegas foi funcionário diplomático, representante na Câmara e ministro de educação em duas ocasiões: 1942 e 1946.

${ }^{66}$ Cacúa Prada, Antonio. Germán Arciniegas. Su vida contada por él mismo. Bogotá. ICELAC. 1990, pp. 184. Poderia se afirmar que a segunda publicação de Arciniegas -La universidad colombiana, Imprenta Nacional, Bogotá, 1932-, foi também resultado da sua temporada inglesa, além de ser uma extensão das pesquisas sobre o mundo estudantil e universitário que concentraram seus investimentos intelectuais na década de 1920 . O texto é um projeto de lei no qual Arciniegas incluiu observações sobre diversas instituições europeias que pode conhecer durante estes dois anos. Sobre os anos 1920, na trajetória de Arciniegas, pode-se consultar: Arias Trujillo, Los leopardos. Una historia intelectual de los años veinte. Bogotá. Uniandes, 2013; e Rivas Gamboa, Angela. "Un estudiante-maestro." Historia Crítica. 2001. Sobre as projeções desta experiência na Argentina da década de 1940, o capítulo "Germán Arciniegas e o mundo universitário argentino". Arciniegas planejou um terceiro livro resultado desta passagem pela Inglaterra, La isla de los caballos, que não chegou a publicar.
} 
experiência política. Mesmo a serviço do cônsul, o economista Alejandro López (1876-1940) que trabalhava intensamente, Arciniegas tinha funções apenas rotineiras. Como López, "tenía que salir mucho, en viajes de su propio oficio, por Europa. Entonces a mí me quedaba más tiempo, y despachaba las cosas del Consulado a una velocidad increíble. La mayor parte de ese oficio es de rutina" 67.

Já na Argentina ${ }^{68}$, Arciniegas teve uma experiência diferente no plano profissional, pois, como lembrou, "no faltaron problemas en la embajada" e ainda "Varias veces estuve a punto de retirarme de la Embajada”. Além disso, contava com uma trajetória política mais madura -tinha sido Deputado na Câmara de Representantes e Conselheiro Municipal - e tinha uma carreira como escritor já mais consolidada (havia publicado, entre 1932 e 1939, sete livros). Nestas condições, Arciniegas pode aproveitar melhor sua dupla condição. Em julho de 1940, escreveu ao seu amigo, o presidente da Colômbia Eduardo Santos (1888-1974):

“A MÍ ME HA IDO MEJOR DE CUANTO PODÍA ESPERAR. HE DICTADO CONFERENCIAS Y
CURSILLOS EN LAS UNIVERSIDADES Y HE ESCRITO LO SUFICIENTE PARA RELACIONARME
CON PERIODISTAS Y CON INTELECTUALES, LO CUAL ME PONE EN MUY BUENAS
CONDICIONES PARA EL TRABAJO MISMO DE LA EMBAJADA. EL OTRO DIA DI UNA
CONFERENCIA EN SANTA FE CON ASISTENCIA DEL GOBERNADOR DE LA PROVINCIA, DEL
ARZOBISPO, DEL MINISTRO DE INSTRUCCIÓN PÚBLICA Y MUCHA GENTE (...) SOCIALMENTE
ESTO TIENE SU IMPORTANCIA, PUES EL DOBLE TÍTULO DE INTELECTUAL Y DIPLOMÁTICO
MEJORA LAS CREDENCIALES PARA ENTRAR EN UNA SOCIEDAD QUE SE PAGA UN POCO DE
ESTAS COSAS"69.

Arciniegas soube capitalizar o prestigio duplo de ser "intelectual e diplomata". Em alguns círculos intelectuais, seu prestígio já era reconhecido - aqueles engajados no processo de reforma universitária que deslanchou em 1918 - mas, em outras ocasiões, foi a fama de outros escritores colombianos que tinham passado por Buenos Aires, especialmente Baldomero Sanín Cano (18611857), que lhe abriu as portas no circuito letrado portenho ${ }^{70}$. Em outros casos foi a diplomacia

\footnotetext{
${ }^{67}$ Cacúa Prada, Antonio, Germán Arciniegas, su vida contada...Op. Cit. pp. 178-196. López foi uma das principiais figuras da República Liberal. Suas ideias sobre a economia nacional inspiraram várias das reformas propostas pelo primeiro governo de Alfonso López Pumarejo, conhecido como "La Revolución en Marcha". Sobre sua trajetória, Mayor Mora, Alberto, Ciencia y utopia. Biografía intelectual y política de Alejandro López, Medellín. EAFIT, 2001. ${ }^{68}$ Em 1939 Arciniegas foi também delegado da Colômbia ao Primeiro Congresso Inter-Americano de Turismo, reunido em São Francisco, Estados Unidos. Ministério de Relaciones Exteriores a G.A., 17/06/1939, Caja 22, Carpeta 28.

${ }^{69}$ G.A. a Eduardo Santos, Buenos Aires, Julio 23, 1940, BNC, FGA, Caja 1, Carpeta 4. Maiúsculas no original.

${ }^{70}$ CACÚA...Op. Cit. p. 227. Cano foi repórter de La Nación na Inglaterra e na França e havia se radicado em Buenos Aires na década de 1920, onde também trabalhou no jornal portenho. Arciniegas lembrou que na Inglaterra também os canais abertos por Sanín foram seu único vínculo com os círculos intelectuais da ilha. "Las relaciones de Sanín Cano le servían a uno de extraordinario pasaporte, no sólo en Inglaterra sino en Escocia, porque Sanín Cano
} 
que abriu caminhos. Com efeito, como se vê em sua correspondência, ele estabeleceu relações com personalidades políticas que lhe resultaram interessantes, fazendo uso de seu status como Ministro Conselheiro ou Encarregado de Negócios da embaixada ${ }^{71}$. Os dois papéis, intelectual e diplomata, se reforçavam mutuamente, atraindo a atenção de auditórios heterogêneos sobre suas atividades, abrindo-lhe espaços privilegiados no interior do campo do poder político e das sociabilidades intelectuais.

$\mathrm{Na}$ nutrida história dos escritores-diplomatas da América Latina durante estas décadas ${ }^{72}$, encontram-se outras versões desta mistura de papéis, de soma de prestígios e capitais simbólicos. Uma especialmente sugestiva é a do poeta mexicano Amado Nervo, um dos primeiros escritores que se vinculou à diplomacia revolucionária voltada para a América do Sul, sob comando de Isidro Fabela. Nervo foi embaixador na Argentina durante a década de 1910. Segundo Nervo, o prestigio dos escritores era essencialmente moral e eles podiam investi-lo nas causas políticas que representavam como diplomatas ${ }^{73}$. No mesmo sentido, afirmava um jornal carioca quando da chegada do mexicano Alfonso Reyes como embaixador, que "se a literatura não faz a diplomacia,

había enseñado en Edimburgo". Ibíd. P. 185. Sobre Baldomero e a sua relação com os círculos portenhos Rubiano Muñoz, Rafael, "Baldomero Sanín Cano en La Nación de Buenos Aires (1909-1957). Prensa, diplomacia e análisis político internacional". Historia y Sociedad No. 25, Medellín, 2013, pp79-106; "Baldomero Sanín Cano y la revista Nosotros (1907-1943). Intercambio y redes culturalese intelectuales". Anuario Colombiano de Historia Social y de la Cultura, vol 41, No. 1, 2014.

${ }^{71}$ Arciniegas não costumava assinar suas cartas indicando o cargo que tinha, mas o fez quando se dirigiu à personalidades que não conhecia e que pertenciam ao mundo da política.

72 A "diplomacia das letras" foi um fenômeno saliente na historia da cultura e da política da região desde o século XIX, quando escritores políticos prestaram seus serviços e circularam pelo continente, embora as missões oficiais não estivessem formalizadas entre os países. O objetivo muitas vezes declarado desses escritores era o de favorecer a compreensão entre os povos americanos. A herança oitocentista foi revigorada na primeira metade do século XX, quando os contatos diplomáticos se formalizaram e os intercâmbios e a circulação cultural - se não a comercial - se fizeram mais densos. Diferentes projetos nacionais tiveram projeções internacionais voltadas para a região, o que fez com que aparecessem vários projetos "americanistas" sob orientações ideológicas e geopolíticas divergentes; e que contaram com a ativa participação de grupos intelectuais nas estruturas dos ministérios de relações exteriores, abrindo espaço ao que se poderia chamar mais apropriadamente como "diplomacia cultural". Sobre os casos das relações latino-americanas de México, Brasil e Argentina pode-se consultar, entre uma extensa bibliografia: CRESPO, Regina, "Cultura e política: José Vasconcelos e Alfonso Reyes no Brasil (1922-1938), Em: Revista Brasileira de História, Vol. 23, No. 45, 2003, pp, 187-208, e "Entre porteños y cariocas. Alfonso Reyes embajador" consultado o 30/11/12 em http://cvc.cervantes.es/literatura/escritores/a reyes/entorno/crespo.htm; GERAB BAGGIO, Kàtia, "Ronald de Carvalho e Toda a Amèrica: diplomacia ensaísmo, poesia e impressões de viagem na sociabilidades intelectual entre Brasil e a Hispano-América" Em: BENDICHO BEIRED, José Luis, CAPELATO, Maria Helena e COELHO PRADO, Maria Ligia, Intercâmbios políticos e mediações culturais nas Américas. LEHA. USP. São Paulo. 2011. YANKELEVICH, Pablo. Miradas australes. Propaganda, cabildeo y proyección de la Revolución Mexicana en el Rio de la Plata, 1910-1930. INEHRM, México 1997; e "México-Argentina. Itinerario de una relación" Em: TZINTZUN, Revista de Estudios Históricos, No. 45, 2007, pp, 83-104.

${ }^{73}$ YANKELEVICH, Pablo, "México-Argentina..." Op. Cit. 
só a pode honrar". Reyes se identificava como parte da "escola" de escritores-diplomatas de Amado Nervo, e foi embaixador na Argentina (1927-1929) e no Brasil (1930-1937, 1939) ${ }^{74}$.

As missões da Colômbia na Argentina, antes da chegada de Arciniegas, tiveram a presença de escritores e homens de letras. Com efeito, o mesmo Sanín Cano foi por algum tempo encarregado dos assuntos diplomáticos durante a década de 1920, quando tomava parte na redação do jornal La Nación, ao qual também veio se vincular um jovem escritor, coevo de Arciniegas, Alberto Lleras Camargo (1906-1990), que foi duas vezes presidente do país (1945-46 e 58-62). Já na década de trinta, o último encarregado de negócios da Colômbia no país austral foi Ricardo Uribe Escobar (1892-1968), reconhecido nos meios literários como talentoso cronista, além de ter sido reitor da Universidade de Antioquia ${ }^{75}$. Junto com ele, o crítico Javier Arango Ferrer (1905-1984), nascido na Antioquia, assim como Sanín Cano e Uribe Escobar, esteve em Buenos Aires como adido cultural. Depois do período Urdaneta-Arciniegas, mais um jornalista liberal, Lucas Caballero (1913-1981), viria a ocupar a embaixada; e após ele, foi a vez de Gustavo Santos, jornalista também, e irmão do ex-presidente. No fim da década, o escritor liberal e amigo de Arciniegas Luis Eduardo Nieto Arteta foi nomeado Conselheiro da Embaixada, onde permaneceu entre 1949 e $1952^{76}$.

Sem fazer menção desses antecedentes, Arciniegas reivindicou nos círculos argentinos uma tradição mais longínqua nas relações diplomáticas e intelectuais entre os dois países, que se alastrava até o século XIX. Em conferência na Academia Nacional de História em Buenos Aires, o escritor lembrou as diligências do padre e político argentino Gregorio Funes (1749-1829) como representante da jovem república da Colômbia na Argentina e a posterior viagem à Bogotá do escritor Miguel Cané (1851-1905) ${ }^{77}$. Arciniegas quis levar até Buenos Aires cartas e outros documentos originais desses personagens para uma projetada exposição do "livro e da arte

\footnotetext{
${ }^{74}$ ELLISON, Fred, Alfonso Reyes e o Brasil, Río de Janeiro, Topbooks, 2002. Desde a década de 1914 até 1927, vários escritores mexicanos foram delegados oficiais na Argentina: José Vasconcelos, Amado Nervo Antonio Mediz Bolio, Julio Jiménez Rueda, Enrique Gonzáles Martínez e Alfonso Reyes, o primeiro embaixador. Ver YANKELEVICH, Pablo, "México-Argentina...Op. Cit.

${ }^{75}$ Quien es quien en Colombia. Bogotá. Oliverio Perry, 1944.

${ }^{76}$ Neto foi funcionário do Ministério de Relações Exteriores em Bogotá e desempenhou cargos diplomáticos na Espanha, no Brasil e na Argentina. Sobre o autor foi publicada recentemente uma excelente biografia intelectual, que contempla análise sobre essas temporadas diplomáticas. Cataño, Gonzalo. La introduccion del pensamento moderno en Colombia. El caso de Luis E. Nieto Arteta. Bogotá. Universidad Externado de Colombia. 2013, pp. 421-438.

77 "Santander y la lucha por la libertad después de la independencia" Revista de las Indias No. 19, Bogotá, Junio de 1940, pp. 319-344, reproducido en también en Boletín de la Academia Nacional de la Historia vol. 41, 1940, pp. 163-179.
} 
colombianos" ${ }^{78}$, como mostra de uma relação política e literária com certa tradição na qual ele próprio podia se inserir.

É significativo, para compreendermos a importância da nomeação de Arciniegas, dizer que foi apenas em 1939 que a representação diplomática em Buenos Aires foi elevada à categoria de embaixada, gesto que logo em 1940 foi correspondido pela Argentina. O primeiro embaixador foi o próprio Roberto Urdaneta Arbeláez, que tinha uma trajetória de grande notoriedade em assuntos internacionais: Urdaneta foi Ministro de Relações Exteriores nos governos de Enrique Olaya Herrera (1930-1934) e de Alfonso López Pumarejo (1934-1938), cargo no qual enfrentou o conflito com o Peru, na Amazônia, antes de ser nomeado por López Embaixador Plenipotenciário em Lima, com o objetivo de vigiar o cumprimento dos acordos de paz assinados no Rio de Janeiro $^{79}$. Segundo Arciniegas, sua nomeação como Ministro Conselheiro seria provisória, levando em conta que, por acordo com Santos (presidente entre 1938 e 1942), Urdaneta renunciaria ao cargo um ano depois e Arciniegas assumiria a titularidade da missão ${ }^{80}$.

Para avaliar as relações entre trabalho intelectual e profissão diplomática, que condicionaram o exercício da mediação cultural de Germán Arciniegas, deve-se levar em conta a presença de escritores no aparato de política exterior em vários países latino-americanos e especialmente nas relações entre Colômbia e Argentina, sejam aquelas lembradas por Arciniegas, sejam aquelas esquecidas. Mas também é preciso reconhecer que as funções oficiais produzem um capital simbólico que os escritores mobilizam em seu proveito. Alguns âmbitos e sociabilidades oficiais que outros escritores não frequentam lhes são abertos, com todas as possibilidades práticas que isso pode acarretar para as atividades propriamente literárias ou intelectuais.

E é preciso assinalar também que os governos do Partido Liberal (1930-1946) ergueram um arranjo entre intelectuais e Estado, que deu aos primeiros posições de destaque e direção para planejar as políticas culturais. Segundo o historiador Renán Silva, a chamada República Liberal

\footnotetext{
${ }^{78}$ G.A. a Luis López de Mesa, Mayo 9 de 1940. BNC, FGA, Caja 1, Carpeta 4.

79. Durante o período da missão, a relação entre Urdaneta e Arciniegas foi amigável, mais que isso, íntima Arciniegas referia-se à mulher de Urdaneta, Clemencia Ospina, com o diminutivo "Clema" e o tom das cartas que este lhe encaminhou nesses anos foi sempre de camaradagem. Mas depois, na década de 1950, Arciniegas mudou sua opinião sobre o ex-embaixador em sentido radicalmente adverso, afirmando que "Urdaneta Arbeláez es um político oportunista" e caracterizando-o como um sujeito fanático da religião católica, educado pelos jesuítas e "el segundo en la jerarquia dictatorial que preside (Laureano) Gómez", sendo o encarregado de organizar a repressão contra os camponeses liberais nesse momento: Entre la libertad y el miedo. Buenos Aires. Sudamericana. 1956, p. 221, 225.

${ }^{80}$ Cacua Prada...Op. Cit, pp. 226.
} 
"representa uma de las etapas de más alta integración entre uma categoria de intelectuales públicos y um conjunto de políticas de Estado", principalmente relativas à extensão cultural e ao Ministério da Educação. Os intelectuais dos governos liberais, ocuparam cargos de destaque no Estado, "al mismo tempo que dominaban em el escenario cultural, sobre todo en la prensa, en la radio y en el precario mundo del libro, lo que les garantizaba una posición directiva" sobre os destinos da nação ${ }^{81}$.

Consideramos que a presença dos intelectuais ocorreu também no Ministério das Relações Exteriores e Culto, mas não podemos afirmar que, como no caso das políticas de extensão cultural, as iniciativas de política exterior foram elaboradas por esses intelectuais.

\section{Trabalho diplomático e jornalismo.}

Segundo palavras de Alfonso Reyes, o trabalho diplomático e o intelectual mantém uma afinidade básica: os escritores teriam uma vantagem sobre os diplomatas profissionais, não só pelos "motivos de relumbrón" associados a uma aura especial, que era mais ou menos o que enxergava Arciniegas, mas porque eles são "técnicos da expressão". Reyes mencionava que os escritores eram especialistas em inventar tons e calibrar os alcances das palavras, calar certas coisas e saber dizer outras, o que tem tudo a ver com o trabalho do diplomata. Assim, a presença dos escritores no serviço diplomático não seria acidental, mas orgânica, o que chegou a defender em informe aos seus superiores ${ }^{82}$.

As afinidades entre trabalho intelectual e diplomático passavam por outros caminhos e por outras visões na experiência de Arciniegas. Boa parte das funções que ele desempenhou teve um elo forte com sua atividade intelectual mais constante até então: o jornalismo. Arciniegas era um dos escritores mais influentes do jornal El Tiempo, propriedade de Eduardo Santos, que era um importante espaço de sociabilidade intelectual e política desde os anos 1920. Como ficou dito, desde seu regresso da Inglaterra, Arciniegas tinha ocupado vários cargos públicos e, ao mesmo tempo, tinha escalado posições em sua carreira como jornalista: foi encarregado da direção do

\footnotetext{
${ }^{81}$ Silva, Renán. República Liberal...Op. Cit., pp. 22.

${ }^{82}$ ELLISON, Fred, Alfonso Reyes...Op Cit.
} 
jornal El Tiempo em 1937 e dirigiu, desde sua fundação, em 1938, a Revista de las Indias - o órgão de articulação intelectual de mais alto nível dos governos liberais ${ }^{83}$. Em abril de 1938, viajou a São Francisco (Estados Unidos), em "viagem de estudos", onde permaneceu oito meses, mantendo apenas a direção da revista. Após sua chegada a Buenos Aires, em dezembro desse mesmo ano, voltou a colaborar com El Tiempo, escrevendo notas e artigos para o Suplemento Literário dos domingos. Também começou a encaminhar a El Tiempo trechos dos jornais argentinos para que a opinião pública colombiana fosse informada das atividades da embaixada ${ }^{84}$.

O escritor se encarregou de monitorar o tipo de informação que as agências internacionais particularmente a United Press - e a imprensa local difundiam sobre a realidade e as políticas colombianas para fazer aclarações e solicitar retificações quando fosse preciso. $\mathrm{O}$ fato de Arciniegas colaborar com os jornais da "grande imprensa" portenha, La Nación e La Prensa, facilitava essas funções e o deixava em condições excepcionais perante outros funcionários da diplomacia latino-americana. Numa carta a Santos, Arciniegas informava a seu "querido doctor" que:

“DE ACUERDO CON SU CABLE DE AYER, ENTREGUÉ A "LA NACIÓN" LA NOTA QUE HOY SE HA PUBLICADO SOBRE EL REPORTAJE DE ORTIZ ECHANGÜE. LA ACOGIERON MUY AMABLEMENTE EN LA PÁGINA EDITORIAL. AUNQUE ERA ELEMENTAL QUE ASÍ LO HICIERAN, ME HA COMPLACIDO PUES YA USTED SABE LA SUERTE QUE CORRIÓ UNA ACLARACIÓN SEMEJANTE QUE QUISO HACER EL EMBAJADOR DE MÉXICO"85

Arciniegas escrevia com bastante frequência no Suplemento Literário de La Nación desde sua chegada à Argentina. Essa vinculação que, está claro, era resultado da qualidade como escritor, se devia também às lembranças que tinham deixado outros compatriotas que escreveram para o jornal nos anos anteriores, abrindo espaços e criando circuitos de solidariedade e colaboração entre certas comunidades de letrados colombianos e argentinos. Arciniegas o reconheceu desta maneira anos depois: "aproveché también el prestigio que había dejado como un rastro maravilloso, Baldomero Sanín Cano”, “Sanín Cano tenía muy buen nombre en Buenos Aires.

\footnotetext{
${ }^{83}$ RESTREPO YUSTI, Manuel. "La Revista de las Indias, un proyecto de ampliación de fronteras. Boletín Cultural y Bibliográfico. Vol. 27, No. 23, pp. 25;41.

${ }^{84}$ Ver BNC, FGA, Caja 20, Carpeta "El Tiempo".

${ }^{85}$ G.A. a Eduardo Santos, Buenos Aires, Março 23, 1941. BNC, FGA, Caja 1, Carpeta 5; Arciniegas escreveu também ao diretor de El Tiempo Fabio Restrepo, preocupado com a informação que circulava sobre Colômbia. G.A. a Fabio Restrepo, Julio 02 de 1940, BNC, FGA, Caja 1, Carpeta 4.
} 
Había sido representante de "La Nación" en París y en Londres y la gente se acercaba a mí un poco por la curiosidad de que les contara sobre la vida de Sanín Cano" $"$.

Arciniegas dedicou-se também a informar aos jornais portenhos sobre a política exterior de Santos frente a II Guerra Mundial e acerca dos acordos sobre limites territoriais negociados com a Venezuela. É bom mencionar que durante o conflito mundial, a Colômbia exerceu um papel saliente na política interamericana, colocando-se como um dos principais aliados dos Estados Unidos no sentido de agir com uma política comum no continente. Isso chocou com certas tendências no governo e na sociedade argentina, interessados em manter a tradição de independência frente à potência do norte e a vinculação estreita aos mercados europeus. Neste sentido, o ganho da delegação colombiana foi a divulgação das propostas de Santos em âmbito internacional, sempre por meio da imprensa liberal ${ }^{87}$.

Arciniegas foi também encarregado de escrever informes para Santos sobre a politica interna da Argentina. $\mathrm{O}$ escritor acompanhava suas cartas-informes - nas quais misturava assuntos pessoais com matérias próprias dos informes oficias - com trechos da imprensa argentina. Encaminhadas diretamente ao presidente e não ao Ministro das Relações Exteriores, as cartas e os trechos de imprensa pretendiam que Santos, ele também jornalista de ofício, tivesse "de mão própria" uma imagem do estado da opinião pública no país. Mas embora Arciniegas quisesse que Santos conhecesse o clima dessa opinião, ele não oferecia ao presidente uma visão plural que refletisse a conflitante diversidade discursiva do espaço público argentino. Para ressaltar esse aspecto, basta contrastar essas cartas com os exaustivos informes encaminhados desde a Argentina por Alfonso Reyes aos seus superiores do Ministério no México, nos quais se mostrou sempre atento às vozes da imprensa católica e operária, além, é claro, dos órgãos liberais. O contraste com essa prática diplomática de Reyes salienta também o contato direto e pessoal, não burocratizado, que mantinha Arciniegas com $\operatorname{Santos}^{88}$.

\footnotetext{
${ }^{86}$ CACÚA PRADA...op. Cit. pp. . 227. Sobre Cano: RUBIANO MUÑOZ, Rafael, "Baldomero Sanín Cano en La Nación de Buenos Aires (1909-1957). Prensa, diplomacia e análisis político internacional”...Op. Cit.

${ }^{87}$ SENKMAN, Leonardo, "El nacionalismo y el campo liberal argentinos ante el neutralismo: 1939-1943." Estudios Interdisciplinarios de América Latina y el Caribe, Vol. 6, $N^{o}$ 1, enero-junio de 1995, pp. 23-50.

${ }^{88}$ MYERS, Jorge, "El intelectual-diplomático: Alfonso Reyes, sustantivo" En: ALTAMIRANO, Carlos (director). Historia de los intelectuales em América Latina, v. II. Los avatares de la "ciudad letrada" en el siglo XX. Buenos Aires, Katz, 2010. pp. 82-97.
} 
É notória a articulação mediada por Arciniegas entre as casas da grande imprensa - La Nación e La Prensa do lado argentino e El Tiempo do lado colombiano - e as tribunas de setores da politica e das letras associados aos polos liberais de cada país. É importante mencionar também que essa articulação era mais do que um gesto informal restringido ao encaminhamento de trechos recortados dos jornais e notas informativas e que tampouco era restringida à experiência pessoal de Arciniegas, pois ele não foi nem o primeiro nem o único intelectual colombiano vinculado a essas casas simultaneamente - já mencionamos a Sanín Cano e Lleras Camargo. Por outro lado, vários exilados da república espanhola que encontraram nos setores liberais portenhos refúgio e acolhida, se vincularam também a El Tiempo já antes da chegada de Arciniegas a Buenos Aires. Foi o caso de Ramón Gómez de la Serna (1888-1963) e Ángel Osorio y Gallardo (1873-1946).

Voltando às afinidades do trabalho jornalístico e diplomático, seria interessante apontar que Arciniegas não escreveu informes periódicos e sistemáticos sobre a vida política e cultural da Argentina, como o fizeram outros escritores-diplomatas ${ }^{89}$. As cartas para Santos são documentos redigidos com agilidade e ironia, no estilo jornalístico costumeiro em Arciniegas e nas quais, como foi dito, embaralha assuntos pessoais e oficiais. Além disso, Arciniegas parece ter ficado todo o primeiro semestre de 1940 dedicado exclusivamente a seus assuntos de "diplomacia cultural" - principalmente à preparação de uma exposição de livros e arte colombiana - e às suas atividades intelectuais pessoais - conferências em universidades e ateneos- mais do que em diligências burocráticas da embaixada, como redigir informes ou tratados comerciais. Isso só veio a acontecer entre julho e novembro de 1940, enquanto o embaixador Urdaneta esteve ausente de Buenos Aires e Arciniegas teve que atuar como Encarregado de Negócios. Só então Arciniegas redigiu as primeiras cartas-informes para seu amigo, o presidente ${ }^{90}$.

\footnotetext{
${ }^{89}$ Ibid.

90 Por isso, no começo desta correspondência, Arciniegas relatou: "NO HE VUELTO A ESCRIBIRLE PRINCIPALMENTE PORQUE ME PARECE QUE CON LOS INFORMES DEL DOCTOR URDANETA, QUE SON MAGNÍFICOS, HABRÁ TENIDO USTED TODO LO QUE NECESITA PARA SABER DE POLÍTICA EN LA ARGENTINA". G.A. a Eduardo Santos, Buenos Aires, Julio 23, 1940. BNC, FGA, Caja 1, Carpeta 4.
} 


\section{Respaldo material}

Outra frente de análise das relações que estabeleceu Arciniegas entre a diplomacia e o exercício do intercâmbio cultural, reside no respaldo material que oferece o Estado às atividades de seus representantes. Essa dimensão é obvia, mas não o são os mecanismos pelos quais os funcionários mobilizam esse apoio para garantir sucesso às suas atividades. Esse suporte é determinante para conferir aos escritores o prestigio associado à representação oficial e é a base para que possam agir como representantes de um universo intelectual e artístico nacional, ou seja, para que possam garantir a efetividade de suas iniciativas de mediação. Sem dúvida, o papel de representantes e mediadores atrai maior interesse sobre suas atividades no ambiente intelectual que recebe a mediação e contribui para o enraizamento do prestigio do escritor.

Um recurso simples que dá mostra da vantagem que representou para Arciniegas o fato de ser diplomata é o correio oficial, que se pode usar como canal para o envio, por exemplo, de livros. De fato, os consulados e embaixadas funcionavam como canais e depósitos bibliográficos. Antes de seu desembarque em Buenos Aires, Arciniegas já pedia a quem fora o representante da Colômbia na Argentina, Ricardo Uribe Escobar, para fazer chegar seu livro Los Comuneros ao influente historiador argentino Ricardo Levene (1885-1959), a quem Arciniegas não conhecia pessoalmente. Quando foi a São Francisco, Estados Unidos, sem missão oficial, pediu ao cônsul nessa cidade para cuidar de alguns livros que enviou desde Bogotá. Depois, já como funcionário diplomático em Buenos Aires, distribuiu entre seus amigos portenhos os livros que os colegas colombianos enviavam através da "valija diplomática". Assim publicações de Alberto Miramón para Ángel Osorio y Gallardo, ou de José María Ots Capdequí (1893-1975) para o mesmo Levene $^{91}$. Entre a correspondência de Levene, repousa ainda uma carta pela qual Arciniegas lhe pede o envio, destinado a um colecionador colombiano, de moedas antigas da Argentina ${ }^{92}$. Sempre transitando via mala diplomática.

Arciniegas repartiu da mesma forma algumas publicações com as que esteve intimamente ligado. Foi, por exemplo, presenteando exemplares da Revista de las Indias que o escritor estabeleceu

${ }^{91}$ G.A. a Ricardo Levene, Buenos Aires, 11/06/1941; y G.A. a Angel Osorio y Galllardo, Buenos Aires, 11/06/1941, BNC, FGA, Caja 1, Carpeta 5.

${ }^{92}$ Germán Arciniegas a Ricardo Levene, 23/10/1941. Biblioteca Nacional de Maestros. Archivo Personal Ricardo Levene. Consultado el $\quad$ el $\quad$ en http://www.bnm.me.gov.ar/ebooks/reader/reader.php?mon=5\&dir=09040315\&num img=09040315"> 
contato com o arquiteto, deputado e historiador da arte Martín Noel (1888-1963) ${ }^{93}$. A mesma coisa pode-se dizer de Marcial Nass, o "buen vecino venezolano", a quem Arciniegas subministrava El Tiempo ${ }^{94}$, ou de Américo Ghioldi (1899-1985), a quem fez chegar um número dos Cuadernos del Noticiario Colombiano ${ }^{95}$. Arciniegas também procurou publicações argentinas interessantes para instituições e amigos colombianos, como no caso do diretor do Banco da República, a quem encaminhou a revista América Económica, dirigida pelo paraguaio Natalicio González (1897-1976) ${ }^{96}$. Outro caso foi o das cinco pessoas escolhidas por Arciniegas para receber os exemplares da edição fac-similar do arquivo de Aimé Bonpland, companheiro de Alexandre von Humboldt em sua viagem à América, doados à embaixada pelo Instituto de Botânica e Farmacologia de Buenos Aires ${ }^{97}$. Arciniegas distribuiu livremente o material cultural doado à embaixada.

Iniciativas como o planejamento e o traslado de exposições de livros e arte ou a instalação de monumentos foram ocasiões para Arciniegas mobilizar recursos e colaboradores no Estado colombiano, como mostraremos um pouco mais a frente.

A casa da Embaixada.

O apoio logístico, material e simbólico que o Estado oferece aos intelectuais que se desenvolvem como diplomatas têm materializações como a própria casa da embaixada. Essa não só é lugar de moradia, mas também pode sê-lo de reunião, pode se constituir num espaço de sociabilidade à medida da liderança do diplomata-escritor, de seu carisma e seus propósitos e pode determinar a situação de maior ou menor prestígio da missão toda. É nesse sentido que Arciniegas escreveu a Santos informando sobre os benefícios da casa escolhida por Urdaneta para se instalar como o primeiro embaixador da Colômbia na Argentina "EN UN EDIFICIO ESPLÉNDIDO, DE MODO QUE LA

\footnotetext{
${ }^{93}$ Germán Arciniegas a Martìn Noel, 20/08/1940, BNC, FGA, Caja 1, Carpeta 4.

${ }^{94}$ Germán Arciniegas a Marcial Nass, 22/06/1940, BNC, FGA, Caja 1, Carpeta 4.

${ }^{95}$ Publicação do embaixador em San José, Costa Rica, Plinio Mendoza Neira. Cada caderno era dedicado a um autor ou corrente literária colombiana. O quarto volume foi dedicado a Arciniegas.

${ }^{96}$ G.A. a Julio Caro, Buenos Aires, 30/09/1940, BNC, FGA, Caja 1, Carpeta 4.

97 G.A. a Juan A. Domínguez, Buenos Aires, 24/09/1940, BNC, FGA, Caja 1, Carpeta 4.
} 
PRESENTACIÓN ESTÁ POR ENCIMA DE LA MAYOR PARTE DE LOS PAÍSES QUE NO SON GRANDES POTENCIAS ${ }^{\prime \prime 98}$.

Arciniegas não chegou como embaixador a Buenos Aires e, portanto, não morou na casa da embaixada localizada na Rua Zabala, 1848. O escritor alugou uma casa na Rua Villanueva, 1369, a menos de um quarteirão de distância da embaixada, onde ocorreu um incêndio em meados de 1940 por causa de um dano na calefação ${ }^{99}$. Ainda assim, permaneceu na casa alugada até o começo de 1941, quando o embaixador Urdaneta deixou definitivamente Buenos Aires. Arciniegas, então, decidiu ocupar a casa da embaixada até a chegada do novo embaixador, Lucas Caballero. Mas, no começo de março, considerando que Caballero não havia chegado, entendeu que era melhor mudar a sede da missão. Nesse momento já havia mudado de opinião sobre a casa e sua correspondência com o status da delegação colombiana:

"mi impresión general es la de que resultaría excesivo, mientras no haya Embajador, ocupar ese inmenso caserón, que entre menos se toque menos complica las cosas y que a primera oportunidad podría cambiarse por una instalación un poco más chica y más acorde con nuestras condiciones económicas, y con nuestra misma representación "'100.

Considerando não apenas a condição da nação representada, mas também que o Encarregado de Negócios estava procurando onde morar foi que as mudanças de opinião a respeito da casa continuaram e antes de acabar o mês Arciniegas já escrevia assim ao presidente:

“COMO LE DIJE A USTED EN MI CABLE ÚLTIMO, RESOLVIMOS OCUPAR LA CASA DE LA EMBAJADA, PUES NOS RESULTABA ABSURDO PAGAR UN BUEN HOTEL Y SEGUIR SOSTENIENDO CERRADA, Y PARA SÓLO EFECTOS DE LA OFICINA DE LA CANCILLERÍA, LA CASA. GABRIELA TUVO MUY BUENAS IDEAS PARA ARREGLARLA DISMINUYENDO GASTOS INÚTILES, LO CUAL HICIMOS DEJANDO LA PARTE DE RECEPCIÓN INDEPENDIENTE, Y DISPUESTA SÓLO PARA CUANDO SE HAGA UNA RECEPCIÓN O COMIDA GRANDE, Y ORGANIZANDO EN LA PARTE ALTA UNA CASA COMPLETA CON RECEPCIÓN Y TODO, DE ESTE MODO SE REDUCE EL PERSONAL DE SERVICIO A LA MITAD Y LOS GASTOS DE ELECTRICIDAD CREO QUE HAYAN DE QUEDAR MUY NOTORIAMENTE DISMINUÍDOS. ESTO NOS HA TRAÍDO DESCANSO Y OPTIMISMO, Y TENGO LA ESPERANZA DE QUE NOS PERMITA VIVIR MÁS TRANQUILOS Y DAR MAYOR RENDIMIENTO EN EL SERVICIO"'I0I

A casa do embaixador é assunto relevante. Ela serve não só como moradia, mas também como ponto de encontro para intelectuais e políticos. Com efeito, Arciniegas recebia, mesmo antes de morar ali, personalidades como Marcial Nass e Macedonio Fernández (1874-1952), mas seu caso

98 G.A. a Eduardo Santos, Buenos Aires, Julio 23, 1940. BNC, FGA, Caja 1, Carpeta 4.

${ }^{99}$ G.A. a Guillermo Federico Walker, Buenos Aires, 03/06/1940, BNC, FGA, Caja 1, Carpeta 4.

${ }^{100}$ G.A. a Eduardo Santos, Buenos Aires, Marzo, 1941. BNC, FGA, Caja 1, Carpeta 5.

${ }^{101}$ G.A. a Eduardo Santos, Buenos Aires, Marzo 29, 1941. BNC, FGA, Caja 1, Carpeta 5. 
não foi tão longe, visando formar um espaço de sociabilidade como o que construiu Alfonso Reyes quando ocupou a embaixada mexicana no Rio de Janeiro ${ }^{102}$.

Finalmente, vale a pena apontar que a casa de Arciniegas e a embaixada ficavam muito próximas ao bairro Belgrano, que era um dos preferidos do escritor, pois nele encontrava um espaço urbano ainda sem a verticalização dos aranha-céus que já ocupavam o centro da cidade. Em Belgrano, se sentia mais à vontade no meio das casas amplas, baixas, com varandas e telhados de barro, que lhe faziam lembrar as casas coloniais da Bogotá natal ${ }^{103}$. Além disso, a proximidade entre o trabalho e a casa lhe permitia dedicar tempo à família, pois, no momento de chegada a Buenos Aires, Arciniegas já era pai de duas filhas que sofreram os rigores do clima portenho, adoecendo em várias ocasiões durante esses dois anos.

\section{Ganhar amizades}

Em sua reflexão sobre a temporada carioca de Alfonso Reyes, o crítico e historiador Fred Ellison ressalta outra similitude entre o trabalho diplomático e o intelectual, assinalado pelo mesmo Reyes: "ganhar amizades", o que quer dizer, “a captação de boas vontades" ${ }^{104}$. É fato que o encontro e a construção de alianças, sejam elas institucionais, acadêmicas ou financeiras, são básicos a toda empreitada científica ou intelectual. Ellison assinala que na formação de redes de colaboração diplomática ou intelectual podem ser privilegiadas as condições carismáticas do escritor e sua qualidade moral sobre o conteúdo ideológico das causas que se vê levado a defender, ou mesmo dos atributos literários de sua obra.

Na Argentina, Germán Arciniegas estabeleceu uma parceria chave com o ex-presidente Gal. Agustín P. Justo (1876-1943). O general brindou-lhe sua colaboração em várias ocasiões. A primeira delas foi quando da preparação da Exposição do Livro Colombiano. Arciniegas escreveu ao diretor da Librería Colombia que "A causa de aficiones comunes en materia de libros, he

\footnotetext{
102 ELLISON...Op. Cit. p. 40. Segundo o escritor mexicano, "Una casa buena y decorosamente instalada pone inmediatamente a la misión en un alto nivel, y permite al representante desenvolverse con cierto aplomo en el mundo en que actúa, aún cuando no se le aumenten sus honorarios personales". Durante sua temporada carioca, Reyes morou em Laranjeiras, bairro habitado por outros embaixadores e escritores, o que contribuiu para o duplo objetivo de se afastar do mundo em meio a um entorno vegetal, com vista para a baia e para as montanhas, além de receber visitas. Ellison sublinha que a embaixada foi ponto de encontro de personagens políticos e intelectuais tão heterogêneos que dificilmente iriam se encontrar noutros espaços da cidade.

103 “Buenos Aires, las tejas y los gatos”. El Tiempo, 06/09/1940.

${ }^{104}$ Segundo Ellison Reyes adotou essa expressão do socialista argentino Juan B. Justo.
} 
venido a hacerme amigo del Gen Agustín P. Justo, ex Presidente de la República, y una de las personas que tienen en la Argentina más selecta biblioteca"105. Arciniegas queria transmitir ao livreiro o pedido particular que Justo lhe fez para fornecer sua biblioteca com livros colombianos. Esses livros, disse Arciniegas, serviriam a ele próprio para enriquecer a exposição projetada tendo em vista à demora das instituições colombianas para o envio dos materiais que tinha solicitado. Além disso, continuava Arciniegas, os livros representariam um valioso aporte ao conhecimento da Colômbia na Argentina depois que o general morresse, pois seu acervo iria se converter numa das mais importantes bibliotecas públicas do país.

Um ano depois, tratando agora do projeto de monumento a Santander, Justo voltou a dar a mão a Arciniegas. Assim relatou o escritor para o presidente da Colômbia:

“EL INTENDENTE ME DIJO QUE ESTABA DISPUESTO A HACER UNA FIESTA EN GRANDE, Y ME ADELANTÓ QUE A NOMBRE DE LA MUNICIPALIDAD HARÍA QUE HABLARA EL EXPRESIDENTE JUSTO. AUNQUE JUSTO ES CONSERVADOR, LO MISMO QUE EL INTENDENTE, ME PARECE QUE NO PUEDE ENCONTRARSE OTRA PERSONA DE MAS SIGNIFICACIÓN PARA EL CASO. DÁ LA CASUALIDAD DE QUE JUSTO ES VERSADO EN HISTORIA DE COLOMBIA Y PRESISAMENTE EL AÑO PASADO LE AYUDÉ A CONSEGUIR UNA COLECCIÓN DE LA BIBLIOTECA DE LA ACADEMIA DE HISTORIA Y OTRA DEL BOLETÍN DE LA MISMA ACADEMIA QUE TIENE EN LUGAR PREFERENTE DE SU BIBLIOTECA, JUNTO CN EL ARCHIVO DE SANTANDER" "I06

Com isso mostramos até que ponto a colaboração pode superar as distâncias simbólicas projetadas pelas produções intelectuais ou pelos discursos políticos ${ }^{107}$. Mas também serve para destacar o alto status das novas amizades do escritor, que obteve a colaboração de quem fora a figura saliente dos governos da década anterior. É bom mencionar também que Justo, apesar da sua participação no golpe de 1930, mantinha uma relação de amizade e colaboração com círculos intelectuais e artísticos da elite portenha aos quais veio se vincular Germán Arciniegas, tais como a Associação Amigos da Arte e a Academia Nacional da História.

${ }^{105}$ G.A. a Luis Escobar, Buenos Aires, Mayo 24, 1940. BNC, FGA, Caja 1, Carpeta 4.

${ }^{106}$ G.A. a Eduardo Santos, Buenos Aires, Marzo, 1941. BNC, FGA, Caja 1, Carpeta 5.

107 ABBOT, Andrew, Department and discipline: Chicago sociology at one hundred. Chicago, 1999. 


\section{Capítulo 2. O trabalho diplomático de Germán Arciniegas na Argentina.}

\section{Introdução}

Arciniegas desempenhou várias funções como Ministro Conselheiro, e posteriormente, como Encarregado de Negócios da Embaixada colombiana em Buenos Aires, funções que foram, respectivamente, da ordem da política cultural e da comercial. Ambas as ordens seguiram uma orientação pan-americanista como defendida pelo então presidente Eduardo Santos. Segundo a correspondência de Arciniegas, identificamos atividades como as seguintes, desenvolvidas por ele como Ministro Conselheiro, todas elas focadas no trabalho cultural: conseguir bolsas para estudantes colombianos de Agronomia e Química nas Universidades de La Plata e do Litoral ou contratar alguns estudantes argentinos nessas áreas para analisar e projetar estratégias para o melhoramento da produtividade agrícola na Colômbia ${ }^{108}$; instalar uma estátua de Santander; enviar duas exposições de arte para Bogotá e Medellín e organizar a exposição do livro e da arte colombiana em Buenos Aires. Já como Encarregado de Negócios, as principais atividades do escritor foram: a preparação de tratados comerciais, a defesa da política de neutralidade perante a II Guerra Mundial (1939-1945) e a observação da política interna argentina. No desempenho de cada uma dessas funções, Arciniegas teve que relacionar-se com diferentes instâncias do aparelho estatal colombiano, e desse relacionamento decorreram os sucessos e fracassos das suas iniciativas. A intencionalidade das empreitadas foi, na maior parte das vezes, explicitada pelo escritor em cartas aos seus interlocutores colombianos, e passavam por ser intervenções pedagógicas sobre o público colombiano e a seleção e promoção de uma imagem da tradição cultural e a política colombiana entre o público argentino.

Exposições de arte. Pedagogia e formação do público.

Uma das iniciativas que Arciniegas se propôs a realizar desde sua posição como funcionário diplomático, foi o traslado de exposições de gravuras de artistas do circuito bonaerense até a Colômbia. $\mathrm{O}$ interesse do escritor diplomata pela arte não era uma novidade, e se entrosava com

\footnotetext{
${ }^{108}$ A iniciativa contemplava poucas becas por apenas uma ocasião, e não um acordo de intercâmbio como os que foram assinados entre outros países nesses anos. Arciniegas optou afinal por contratar jovens argentinos já formados para trabalhar na Colômbia ao invés de fornecer a estudantes colombianos as ditas bolsas de estudo. G.A a Eduardo Santos, Buenos Aires, 23/07/1940, BNC, FGA, Caja 1, Carpeta 4; G.A a Guillermo Nanetti, Buenos Aires, 22/08/1941, BNC, FGA, Caja 1, Carpeta 5.
} 
os primórdios de sua atividade intelectual na década de 1920. Arciniegas tinha se mostrado mais do que atento às novidades artísticas de seus contemporâneos: o jovem "agitador cultural" havia reservado um espaço, em suas reflexões e na revista Universidad que ele dirigia, às expressões dos jovens desenhistas, pintores, escultores, e até fotógrafos do país ${ }^{109}$. Junto a Baldomero Sanín Cano, quem eventualmente chegou a assumir a direção de Universidad, Arciniegas fez da revista um palco de promoção e renovação das artes no país, e ele próprio se converteu, segundo o historiador da arte Álvaro Medina, no "intelectual que mais e melhor estimulou as buscas que empreenderam os artistas da sua geração"110.

Isso explica que na sua passagem pela capital argentina o escritor não limitara seus interesses às atividades literárias ou jornalísticas. E também que seu interesse, como tinha sido vinte anos atrás, não fosse o do crítico especializado, mas o do animador que procurava fornecer novidades com um sentido pedagógico, ao público e aos artistas de seu país. Assim, escrevia a respeito das peças que pretendia levar até Bogotá que "Es imposible presentar nada mejor para educación del público y de los mismos artistas que estos grabados" 111 , em carta a quem foi seu principal colaborador para levar as exposições até Colômbia, Darío Achury Valenzuela (1906-1999). diretor do Departamento de Belas Artes no Ministério de Educação.

Arciniegas se referia às gravuras do artista flamenco Víctor Delhez (1902-1985), radicado na Argentina $^{112}$, de quem fez elogiosa apresentação para os leitores de El Tiempo salientando várias características de sua obra e sua personalidade ${ }^{113}$, e reforçando o sentido pedagógico da empreitada. Redigido para "ir haciendo ambiente", como disse Achury, à exposição do gravurista em Bogotá, o artigo de Arciniegas chamava atenção em primeiro lugar, para as qualidades morais de quem seria "uno de los artistas más grandes del mundo de nuestro tempo", a começar pela

\footnotetext{
${ }^{109}$ Não existe um estudo sobre as opiniões artísticas do escritor, mas pode se constatar a existência de escritos dedicados ao muralista Pedro Nel Gómez, ao grupo de escultores e pintores "Bachué", aos escultores de madeira Ramón Barba e José Domingo Rodríguez e ao fotógrafo Luis B. Ramos, entre outros artistas colombianos da década de 1920. Nos anos 1930 Arciniegas escreveu também um texto sobre "o sentido da escultura nacional" e sobre o pintor Gonzalo Ariza. Existe, finalmente, um estudo, já da década de 1970, sobre o famoso pintor e escultor Fernando Botero.

110 MEDINA, Álvaro. El arte colombiano de los años veinte y treinta. Bogotá, Colcultura, 1995, pp. 43. Medina afirma também que Universidad destaca por ser a única, entre as três revistas de renovação literária da década (as outras duas são Voces e Los Nuevos) a se ocupar com a arte.

${ }^{111}$ G.A. a Darío Achury Valenzuela 02/07/1940, BNC, FGA, Caja 1, carpeta 4.

${ }^{112}$ Delhez morou em Buenos Aires entre 1926 e 1933, mudou-se para Bolívia e retornou à Argentina em 1940 para se estabelecer na província de Mendoza como professor universitário.

${ }^{113}$ El poeta de las maderas. Víctor Delhez y su obra. El Tiempo, 09/02/1941.
} 
honestidade de seu trabalho, "una lucha por la honradez en el arte y la dignificación del grabado”, um ofício “consagrado a revivir y renovar un arte, el del grabado en madera (...) que hoy mixtifican sin ninguna honradez quienes se evitan la ruda labor de las cuchillas haciendo imitaciones en tinta china que imprimen luego las imprentas mercenarias”. No mesmo sentido, Arciniegas destacava o fato de Delhez não ser um artista boêmio: "No hay en esto bohemia. No hay abandono. No hay ocio", mas, pelo contrário, disciplina, pois “Todo en la casa de Delhez es pulcritud. Hay un orden, una disciplina que son consubstanciales con su vida y su arte y que se reflejan en todo lo que le rodea”. Em terceiro lugar, Arciniegas festejava o fato de Delhez ter migrado à América e se estabelecido num recanto solitário fugindo das distrações do mundo europeu. Comentando a obra de Delhez, Arciniegas mencionou as virtudes técnicas do flamenco, e por fim destacou um quarto elemento: o fato do gravurista ter feito ilustrações para certo livro traduzido do inglês para o espanhol pelo escritor colombiano Hernando Santos, quem também escrevia para El Tiempo além de ser irmão do dono do jornal e presidente do país, Eduardo Santos ${ }^{114}$.

O artigo de Arciniegas, publicado em fevereiro de 1941, fez parte, como foi dito, da campanha de propaganda para a exposição, que finalmente abriu em março desse ano na capital colombiana, depois de vários adiamentos. As cartas de Arciniegas dão conta da campanha, projetada por Achury, e da qual formaram parte também matérias na Radio Nacional, na Gaceta Cultural e noutros jornais ${ }^{115}$, assim como também na Revista de las Indias ${ }^{116}$. Da mesma forma foi elaborado um catálogo sobre a base do editado pela editora Losada para a exposição das peças em Buenos Aires ${ }^{117}$. Arciniegas mobilizou, então, diferentes instâncias da vida cultural e política do país, atrelando à sua iniciativa o apoio de instâncias privadas como o jornal El Tiempo, mas também de meios oficiais como a Revista de las Indias, que ele próprio dirigia. Mas, sobretudo, contou com o apoio de Achury e do Departamento de Belas Artes que apenas em outubro de

\footnotetext{
114 Trata-se do livro Dreamer's Tales, do escritor irlandês Edward Dunsany. Na correspondência com Achury e Delhez se da conta do interesse que tinham os três em publicar a tradução com as ilustrações na Colômbia, projeto que foi rapidamente esquecido considerando o limitado interesse comercial para os editores privados, e o parentesco entre o tradutor e o presidente do país, se pensando numa edição oficial.

${ }^{115}$ Darío Achury Valenzuela a G.A. 01/1941, BNC, FGA, Carpeta

${ }_{116}$ Martelli, Sixto. Meditación acerca de lacto de grabar. Um ejemplo del primer plano: Víctor Delhez. Revista de las Indias, vol. 10, No. 30 (junho 1941), pp. 72-80.

${ }^{117}$ G.A. a Darío Achury Valenzuela, Buenos Aires, 16/08/1940, BNC, FGA, Caja 1, Carpeta 4.
} 
1940 tinha conseguido abrir o Primeiro Salão de Artistas Nacionais, em Bogotá, um experimento de mecenato oficial para os artistas locais.

O intercâmbio epistolar entre Achury e Arciniegas foi intenso entre 1940 e 1941, e abrangeu não só os assuntos relativos à exposição de Delhez tanto quanto à projetada mostra de livros colombianos em Buenos Aires. O funcionário do Ministério de Educação mostrou-se sempre aberto e colaborativo às iniciativas do diplomático, arcando com os gastos da exposição, inclusive das molduras para as peças, mesmo quando as expectativas de vendas em Bogotá não foram, segundo ele próprio, boas. Achury cuidou de detalhes da exposição como a ordem da sala, o tipo de moldurass e a chegada e retorno das gravuras, do que se dá conta na troca de mensagens entre ele, Arciniegas e o próprio Delhez ${ }^{118}$, nas quais houve apenas o incômodo de algumas peças terem se rasgado nas margens durante a viagem de ida.

Com as gravuras em Bogotá, foi mais fácil abrir uma segunda mostra do flamenco em Medellín, onde a Sociedad Amigos del Arte dessa cidade a acolheu e ainda garantiu a compra de onze das obras para o acervo local, o que representou, depois do fracasso que foi nesse aspecto a exposição em Bogotá, uma alegria para todos os envolvidos. A sociedade era regida por Marco A. Peláez e Teresita Santamaría de González, figura saliente da sociedade antioquenha ${ }^{119}$, e, como Achury, uma das melhores aliadas nas empreitadas de Arciniegas: a matrona colaborou com o escritor também na coleta de materiais para exposição do livro em Buenos Aires, e, posteriormente, com a fundação do Colegio Mayor de Antioquia, instituição de ensino superior para mulheres criada por Arciniegas em 1942, quando ocupou o Ministro de Educação, e do qual Teresita foi a primeira reitora $^{120}$.

Os melhores resultados da exposição em Medellín animaram Arciniegas a planejar o traslado de uma segunda exposição de gravuras desde Buenos Aires. Apesar dos resultados comerciais não terem sido os melhores na capital, Arciniegas julgou a exposição uma iniciativa valiosa para a

\footnotetext{
118 As cartas de Delhez, relativas todas as suas exposições estão em BNC, FGA, Caja 19, carpeta 7.

${ }^{119}$ Os vínculos de Arciniegas com a elite da região decorreram do seu casamento com Gabriela Vieira já na década de 1920.

${ }^{120}$ Teresita era a diretora do "Centro de Estudos" onde assistiam mulheres de Medellín desde a década de 1930, e dirigia a publicação Letras y Encajes, dirigida ao público feminino. Era parte também membro da Sociedad de Mejoras Publicas e foi diretora do Museo de Antioquia. Sobre sua vida: GOMEZ, Daniela, Cómo te olvidan. La historia de Teresa Santamaría de González, Medellín, Letra y Pulso, Instituto de Cultura y Patrimonio de Antioquia, 2014.
} 
cultura nacional $^{121}$. Já o sucesso obtido em Medellín e a colaboração recebida do Ministério de Educação o encorajaram para levar "una espléndida muestra de grabadores argentinos, en la que toman parte los más distinguidos artistas del ramo que trabajan no sólo en Buenos Aires sino en algunas ciudades del interior" "122, até seu país. De novo, pretendeu contar com a colaboração dos Amigos del Arte em Medellín, os Ministérios de Relações Exteriores e de Educação e a Embaixada argentina na capital colombiana ${ }^{123}$. Esta segunda exposição abriu as portas em Bogotá em março de 1942, quando o próprio Arciniegas era o Ministro de Educação, e logo depois passou a Medellín como planejado ${ }^{124}$.

Arciniegas não teve apenas colaboradores na Colômbia. Tanto a exposição de Delhez como a mostra coletiva de gravuristas locais foi exibida em Buenos Aires na Asociacíon Amigos del Arte dessa cidade, uma instância central à cultura portenha, absolutamente consolidada a começos da década de 1940 quando contava mais de vinte anos de atividade. Durante duas décadas Amigos del Arte tinha acolhido outros artistas que, como o muralista Benito Quinquela Martin ${ }^{125}$, receberam a admiração artística e pessoal de Arciniegas, ou como Alfredo Berni, quem visitou a Colômbia em 1942. Com efeito, a Asociación manteve durante duas décadas uma atividade plural onde foram acolhidas não só diferentes tendências da arte plástica como outras formas da arte (teatro, música, fantoches) e mesmo outras atividades culturais como conferências, ou exposições de livros. Fundada em 1924 por Elena Sansinena Elizalde, herdeira de uma família rica de fazendeiros, a Associação foi, sobretudo, expressão do desejo das elites por se manter como guia da evolução cultural do país, e acolheu entre os seus associados figuras salientes da sociedade portenha que de destacavam tanto na política quanto no nascente campo cultural. Algumas dessas personalidades - como o crítico de arte Cayetano Córdova Itarburu, o arquiteto Martín Noel, o ex-presidente gral. Agustín P. Justo, os historiadores Ricardo Levene e Emilio Ravignani, a

${ }^{121}$ Em carta a Luis Augusto Cuervo, Presidente da Acadêmica Colombiâna de História, Arciniegas escreveu: "Ha sido muy sensible el que la Exposición no hubiera sido tan apreciada por los bogotanos como es debido. Yo tengo una admiración sin límites por la obra de Delhez, a quien considero uno de los artistas más extraordinarios de nuestro tiempo. De todos modos, creo que llevando los grabados a Bogotá hemos hecho una buena obra en bien de la cultura de nuestros compatriotas". G.A. a Luis Augusto Cuervo, 15/03/1941. BNC, FGA, Carpeta..

${ }^{122}$ G.A. a Marco A. Peláez, Buenos Aires, 25/08/1941. BNC, FGA, Caja 1, Carpeta 5.

${ }^{123} \mathrm{O}$ embaixador Condiotti tinha tomado parte na inauguração da exposição em Bogotá. G.A. a Alberto Candiotti, Buenos Aires, 31/03/1941, BNC, FGA, Caja1, Carpeta 5.

${ }^{124}$ G.A. a Alberto Candiotti, Bogotá, 24/02/1942, BNC, FGA, Caja 1,Carpeta 6.

${ }^{125}$ Arciniegas escreveu sobre Quinquela Martin em, pelo menos, duas ocasiões. A primeira foi mesmo em 1940 num artigo para El Tiempo, "Benito Quinquela: el más fuerte y vigoroso pintor del puerto de Buenos Aires", 26/05/1940, e a segunda já na década de 1950, "Los caballeros de la orden del tornillo", 09/06/1957. 
proprietária da revista Sur, Victoria Ocampo, o poeta Oliverio Girondo e boa parte dos escritores do exilio espanhol que tiveram no espaço da Asociación uma tribuna para suas ideias como Ricardo Baeza, María de Maetzu, Ramón Gómez de la Serna - foram colaboradores importantes de Arciniegas ${ }^{126}$.

\section{A exposição do livro e a arte colombiana. Mediação e diplomacia cultural.}

A segunda exposição projetada por Arciniegas assinala a direção contrária no traslado de materiais de um país para o outro. Desta vez, livros, cartas e peças artísticas seriam expostos em Buenos Aires, mas com intuitos diferentes ao pedagógico na formação do público. Animavam o escritor objetivos de diplomacia cultural, como a aproximação e o conhecimento mútuo das tradições culturais dos países americanos e a projeção de uma determinada versão da tradição do próprio.

É importante mencionar que as exposições e feiras de livros foram, desde a década de 1930, um mecanismo cada vez mais importante dos intercâmbios culturais entre os países latinoamericanos. Durante os anos 1930 e 1940 teve lugar um trânsito de exposições itinerantes que levaram livros e peças artísticas de um país para outro da América Latina. Só na correspondência de Germán Arciniegas do ano 1940, se faz menção as exposições da arte chilena e mexicana realizadas em Buenos Aires, à do livro equatoriano em Bogotá, do livro argentino em Rio de Janeiro, Santiago de Chile e Lima, e a duas do livro colombiano no Chile (Viña del Mar e Santiago) ${ }^{127}$.

Como todas essas, a exposição do livro e a arte colombiana em Buenos Aires projetada por Germán Arciniegas, era ao mesmo tempo uma iniciativa de integração regional a partir da cultura e um exercício de seleção e definição do valor da cultura nacional exposta, exercícios que acentuam o lugar do mediador. Nesse sentido, o planejamento da exposição acarretou alguns elementos constitutivos da diplomacia cultural naquele momento em voga entre diferentes

\footnotetext{
${ }^{126}$ MEO LAOS, Verónica. Vanguardia y renovación estética. Asociación Amigos del Arte (1924-1942). Buenos Aires, CICCUS, 2007.

${ }^{127}$ Ver também FREITAS DUTRA, Eliane de, "Projetos editoriais e exposições do livro no espaço latino-americano: intelectuais e trocas culturais. 1930-1940" La Plata, 31 de octubre al 2 de noviembre de 2012 sitio web: http://coloquiolibroyedicion.fahce.unlp.edu.ar
} 
governos do continente. De um lado, o objetivo de construir uma imagem da cultura e da política do próprio país, dirigida ao estrangeiro, destinada a impressionar e que fosse, obviamente, favorável. Um objetivo nacionalista que se completa com a leitura que se faz da cultura e da política do destinatário desse discurso e dessa estratégia ${ }^{128}$.

Arciniegas foi, nesse aspecto, claro e ambicioso. Junto ao historiador da arte colombiana Gonzalo Hernández de Alba (1906-1988), o escritor projetou uma mostra retrospectiva da cultura letrada e das artes plásticas do país, que visava exaltar uma tradição cultural, que segundo o autor, era muito maior do que a argentina. Assim se poderia evitar expor apenas as produções mais recentes que deixariam a Colômbia em clara desvantagem se comparadas com a evolução das artes e, sobretudo, da produção editorial portenha do momento. Em palavras de Arciniegas,

"la producción editorial de Colombia en estos años (...) es infinitamente inferior por su calidad y por su cantidad a lo que produce la Argentina. Una presentación en estas condiciones no haría sino poner muy de relieve nuestra inferioridad no sólo en el ramo editorial sino también desde el punto de vista de nuestra cultura. La única forma de darle ambiente, mayor interés y trascendencia a nuestra presentación en Buenos Aires sería la de presentar los antecedentes históricos de nuestra cultura que como usted sabe son desde muchos puntos de vista muy superiores a los de Buenos Aires" "129.

Arciniegas explicava que essa superioridade nos antecedentes da cultura colombiana, perante a argentina, era válida em matéria literária, universitária e plástica:

"por ejemplo la Universidad en Buenos Aires se fundó ya en el siglo XIX, de manera que por este solo aspecto una buena presentación de nuestra vida universitaria desde los tiempos coloniales sería de una enorme importancia. También yo quería mostrar algo de nuestra producción artística desde un punto de vista retrospectivo. No hay puntos de comparación entre la riqueza de pintura y de tallado que nosotros tenemos y la que existe en las iglesias de la Argentina" 130.

Claro que Arciniegas não pensava deixar de apresentar a produção literária contemporânea, da qual tinha sido um animador constante desde a década de 1920, mas pretendia fazê-lo sobre uma panorâmica histórica da cultura colombiana. Destarte, o escritor definiu o segundo nível de

128 DUMONT-QUESSARD, Juliette. De la coopération intellectuelle à la diplomatie culturelle. Les voies/x de l'Argentine, du Bresil et du Chili (1919-1946). Tese de doutorado. Université Sorbonne Nouvelle-Paris 3. 2013.

${ }^{129}$ Germán Arciniegas a Tomás Rueda Vargas, Buenos Aires, Junio 28, 1940. Biblioteca Nacional de Colombia, Fondo Germán Arciniegas, Caja 1, Carpeta 4.

${ }^{130}$ Ibíd. Arciniegas repetiu o argumento inúmeras vezes. A Joaquín Tamayo, por exemplo, diretor da Biblioteca Nacional em 1941, lhe escreveu que "Una muestra editorial de lo que hoy se hace entre nosotros resulta muy pobre frente a lo que se está haciendo en Buenos Aires. Pero hay algo que nos salva, y es una tradición más rica que la de estas gentes". E a Guillermo Nanetti, Ministro de Educação, que "insistiendo sobre la antigüedad en nuestra producción universitaria, no solo haremos algo muy interesante sino que se afirmará la buena idea que del país se tiene como una nación de cultura tradicional". Neste sentido "sugería el envío de obras de pintura universal que existen en Colombia, como cuadros del Greco. Ribera, Morales, Murillo etc., porque dan una idea justa del ambiente que se ha vivido tradicionalmente en el pais". 
objetivos da exposição, mais que como diplomacia como mediação cultural: visava apresentar os novos nomes da literatura colombiana ao público argentino e vinculá-los à indústria editorial portenha, como será discutido mais à frente.

Podemos afirmar que a exposição foi uma das empreitadas mais ambiciosas de mediação que Arciniegas pretendeu fazer como Ministro Conselheiro e Encarregado de Negócios na Argentina. A maior parte das cartas dirigidas a personalidades colombianas entre 1940 e 1941 teve como assunto a preparação do evento. Essa empreitada, no entanto, não foi realizada. Porém, mostra os limites da articulação entre a iniciativa do escritor e as políticas de seu país em matéria de diplomacia cultural. Com efeito, as exposições de livros e arte que percorreram as cidades latinoamericanas nesses anos, foram planejadas e celebradas como sinal do compromisso dos governos da região para se aproximarem, e da importância que tinha adquirido a dimensão cultural nas relações entre esses países.

O sucesso da exposição precisava de agentes e colaboradores. Amigos del Arte, que tinha sido o âmbito portenho onde Arciniegas teve contato com tendências da arte local que quis levar até o seu país, foi também onde encontrou o apoio e o interesse para planejar a exposição de materiais colombianos em Buenos Aires ${ }^{131}$. E não foi por acaso, pois a Associação, no seu propósito de impor uma dinâmica cosmopolita à cultura argentina, já tinha recebido exposições do livro italiano (1927), espanhol (1933) e estadunidense (1939) ${ }^{132}$, projetadas como campanhas diplomáticas focadas na cultura.

Na Colômbia, Arciniegas acudiu a uma variedade maior de instâncias e colaboradores. Como foi dito, já para o planejamento da mostra, Arciniegas contou com a ajuda do historiador Guillermo Hernández de Alba, quem redigiu o catálogo das peças a serem apresentadas na exposição, e que contemplava, em palavras de Hernández, "Presentar la más completa visión de nuestra cultura que arranca en los tiempos coloniales" "133. Com aquele fim era preciso contar com a participação de diferentes ministérios e instituições, o que não aconteceu.

${ }^{131}$ G.A. a Tomás Rueda Vargas, Buenos Aires, 28/06/1940, BNC, FGA, Caja 1, Carpeta 4.

132 MEO LAOS, Verónica. Vanguardia y renovación estética. Asociación Amigos del Arte (1924-1942), Buenos Aires. CICCUS, 2007, pp, 167.

133 "numerosas obras manuscritas debidas a la erudición de catedráticos y discípulos de nuestros magnos Colegios junto con las ediciones primitivas de nuestros Cronistas e historiadores. Algunas de las más notables primicias de la Imprenta, los orígenes del periodismo tanto científico como político junto con las publicaciones del siglo pasado 
Uma das primeiras decepções veio do próprio Ministério de Relações Exteriores, onde esbarrou o desejo de levar até Buenos Aires documentos de Miguel Cané e do Dean Funes, e dessa maneira “OFRECER UNA NOTA DE CORDIALIDAD PARA LOS ARGENTINOS"'134. Esses escritores argentinos foram, respectivamente, representantes diplomáticos da Argentina na Colômbia e da Colômbia na Argentina no século XIX. Arciniegas pretendia encenar com os documentos uma tradição de relações diplomáticas e literárias que ele próprio iria renovar, ora com a própria presença ora com a exposição $\mathrm{O}$ escritor colombiano escreveu, sem sucesso, para o Ministro das Relações Exteriores, o também escritor e liberal Luis López de Mesa (1884-1967), argumentando que o traslado dos documentos seria feito pelos canais diplomáticos e que atendia a um interesse comum com o Ministério, e que era, até certo ponto, a palavra de ordem na época: alimentar a cordialidade e aproximação entre as nações americanas.

Uma segunda negativa surgiu na direção da Biblioteca Nacional, regida então por outro escritor liberal, Tomás Rueda Vargas (1879-1943). A Biblioteca teria encaminhado até Buenos Aires uma quantidade importante de livros contemporâneos, mas nenhum dos materiais antigos solicitados por Arciniegas. Germán escreveu para Rueda mostrando seu desconforto e explicando de novo o sentido do plano retrospectivo, dessa vez não apenas o objetivo diplomático da compreensão entre os povos americanos e de exaltação das suas relações no passado, mas a apresentação da tradição letrada nacional.

Uma terceira fonte de dificuldades, que já tinha sido advertida por Hernández de Alba, decorreu da Igreja Católica. Ainda que o próprio Arciniegas estivesse longe de se apresentar como anticlerical, as relações dos governos liberais com as autoridades eclesiásticas foram difíceis. Daí que as diligências dos colaboradores do escritor - como Hernández de Alba, Darío Achury e José Lloreda Camacho, secretário do presidente Eduardo Santos, assim como Luis Cabal e Luis Eduardo Nieto Arteta, escritores que trabalhavam no Ministério de Relações Exteriores - não tivessem bons resultados, e a última esperança de trazer as peças de arte sacra recaísse na visita

(...) Desde el punto de vista artístico (...) las más selectas obras de cuantos artistas han honrado a nuestra Patria, desde Acero de la Cruz, los Figueroas y el inmortal Vásquez, hasta contemporáneos muy meritorios. La presencia de unos cuantos retratos de las época colonial e independentista completan la visión cultural como que los retratados ocuparon altísimo lugar entre los criollos y muchos son autores de las obras que se pretende exhibir".

${ }^{134}$ Germán Arciniegas a Luis López de Mesa, Buenos Aires, Mayo 09, 1940. Biblioteca Nacional de Colombia, Fondo Germán Arciniegas, Caja 1, Carpeta 4. 
que o embaixador Urdaneta fez a Bogotá no segundo semestre de 1940. O Embaixador poderia se mostrar mais eficiente que o Ministro Conselheiro diante da Biblioteca Nacional, e, sobretudo, da cúria, onde tinha familiares. Porém, suas gestões encontraram de novo a indiferença das autoridades. Tampouco Darío Achury Valenzuela, quem foi diretor do departamento de Belas Artes, e, posteriormente, da Divisão de Extensão Cultural no Ministério de Educação, pôde ser desta vez o colaborador efetivo que já tinha sido quando das exposições de gravuras.

Fora das instâncias estatais, Arciniegas também encontrou obstáculos para obter materiais antigos para a mostra bibliográfica. Foi o caso da Academia Colombiana de História, da qual tinha recebido publicações recentes, "PERO NO COLECCIÓN COMPLETA DE LA BIBLIOTECA, NI LA DEL BOLETÍN, COMO TAMPOCO ALGUNOS DOCUMENTOS QUE PUDIERAN SERVIR PARA DARLE MÁS AMBIENTE A LO QUE SE PRESENTARÁ" "135, disse Arciniegas a Luis Augusto Cuervo, presidente da Academia $^{136}$.

O escritor tentou arranjar os materiais também pelos circuitos privados. Escreveu ao diretor da Livraria Colômbia, em Bogotá, pedindo-lhe o envio das coleções que lhe tinham sido negligenciadas na Biblioteca Nacional e na Academia de História. Arciniegas transmitiu o interesse do ex-presidente da Argentina, gral. Agustín P. Justo, quem era "una de las personas que tienen en la Argentina más selecta biblioteca”, mas que não dispunha de textos colombianos. Segundo Arciniegas, além de garantir a presença das coleções na que "habrá de ser una de las bibliotecas públicas mejores de Buenos Aires”, favorecendo o seu conhecimento no público local, os volumes poderiam lhe servir "para reforzar la Exposición del Libro con estas obras del siglo pasado que no he logrado me sean despachadas por la Academia de Historia ni por el Ministerio"'137. Não é de se estranhar a presença de Justo nessa história. É possível que sua aproximação com o escritor-diplomata decorrera da sua relação com a Asociación Amigos del Arte, que, embora uma empresa cultural privada, recebeu verbas públicas em forma de subsídios. Após interrupção no começo da década de trinta, o subsidio foi renovado no governo do general

\footnotetext{
135 Germán Arciniegas a Luis Augusto Cuervo, Buenos Aires, Mayo 09, 1940. Biblioteca Nacional de Colombia, Fondo Germán Arciniegas, Caja 1, Carpeta 4.

${ }^{136}$ Ibíd. Arciniegas explicou seu pedido a Cuervo, "LO QUE NOSOTROS PODEMOS PRESENTAR CON JUSTO ORGULLO Y LO QUE SERVIRÍA PARA QUE SE NOS APRECIASE COMO UN PUEBLO CULTO ES LA TRADICIÓN QUE SE HACE PATENTE EN LA MISMA BIBLIOTECA DE LA ACADEMIA”,

137 Germán Arciniegas a Luis Escobar, Buenos Aires, Mayo 24, 1940. Biblioteca Nacional de Colombia, Fondo Germán Arciniegas, Caja 1, Carpeta 4.
} 
Justo, um "militar con vocación civil"138 que ainda tomava parte em algumas das sessões da Asociación ${ }^{139}$. No seu governo, por outro lado, participaram pessoas ligadas à Asociación, como o próprio filho de sua diretora Elena Sansinena. É claro que não apenas a Associação era ponto de apoio de Arciniegas, quem argumentava frequentemente os seus pedidos às instituições colombianas, mencionando o ótimo ambiente para a exposição que existia em Buenos Aires em meio a diferentes círculos ${ }^{140}$.

Por fim, Arciniegas dirigiu-se aos Amigos del Arte, mas de Medellín. Em carta à sua colaboradora antioquenha Teresita Santamaría, o escritor se queixava das autoridades públicas do Departamento de Antioquia que tampouco se mostraram dispostas a lhe encaminhar livros e peças antigas da arte regional até Buenos Aires. Arciniegas opinava que Teresita era "una especie de gobernadora permanente que manda más en Medellín que las autoridades políticas”, e que poderia influenciar o governo da província no sentido de liberar esses materiais ${ }^{141}$. Disse-lhe, também, que apenas pedia essa ajuda porque estava "ya demasiado comprometido en Buenos Aires".

Como dito antes, Arciniegas cuidou de encenar a tradição cultural de Colômbia com dois objetivos. Primeiro o de frisar, na comparação com a Argentina, a riqueza da cultura do país especialmente durante o período colonial; e segundo, articular a produção literária colombiana à Argentina, muito mais dinâmica na década de 1940. O escritor expôs esse propósito em 1941 pedindo infrutuosamente, mais uma vez, material do período colonial. Após um ano de gestões, em carta para Joaquin Tamayo, novo diretor da Biblioteca Nacional e para Guillermo Nanetti, novo Ministro da Educação. Escreveu a Tamayo:

\footnotetext{
${ }^{138}$ ROMERO, Luis Alberto. Breve historia contemporánea de la Argentina. Buenos Aires. FCE, 1994, p. 93.

${ }^{139}$ MEO LAOS...Op. Cit, pp, 153.

140 "un magnifico ambiente que sin (ilegible) puedo decirle que he contribuido a formar un poco. Lo mejor de los españoles residentes aquí y de los argentinos que valen algo están dispuestos a ayudarnos para que la exposición tenga buen ambiente, y en cuanto a la prensa, es lo más favorable que pueda suponerse". Germán Arciniegas a Joaquín Tamayo, Buenos Aires, Febrero 10, 1941. Biblioteca Nacional de Colombia, Fondo Germán Arciniegas, Caja 1, Carpeta 5

${ }^{141}$ Germán Arciniegas a Teresita Santamaría de González, Buenos Aires, Abril 08, 1941. Biblioteca Nacional de Colombia, Fondo Germán Arciniegas, Caja 1, Carpeta 5"Como la vez pasada inútilmente me dirigi a la Gobernación pidiéndole material antioqueño, y como usted es $s$, quiero pedirle como un favor personal el que me haga enviar o me envie usted de cualquier forma los libros de Tomás Carrasquilla y si es posible algunos otros como los de Gutierrez González, Pacho Rendón, Camilo Antonio Echeverri, et., (...) Si usted lograra interesar un poco al Gobierno y obtuviera que nos mandaran prestado el retrato de Carrasquilla que hizo Eladio Vélez; si además me consiguiera algunos manuscritos de Carrasquilla y dos o tres cosas más, creo que por este aspecto la exposición tendría un grande interés".
} 
"Usted apenas alcanzará a imaginarse el desenvolvimiento que toma ahora aquí el negocio editorial. Hay casas que crecen como espuma, y que muy pronto alcanzarán proporciones que no conocieron las de España. De tal suerte que nosotros debemos vincular un poco a Colombia dentro de este movimiento."

E disse a Nanetti que a mostra

"No solamente va a estimular relaciones de todo orden entre la Argentina y Colombia, principalmente entre las universidades, asociaciones científicas, academias y bibliotecas, sino que es muy posible que se les vaya abriendo camino a los autores colombianos en este nuevo mercado editorial que consagra continentalmente a los escritores".

Arciniegas preocupou-se em levar a Buenos Aires alguns nomes notórios das novas letras e as artes nacionais, figuras e obras que ele próprio tinha contribuído para divulgar nos meios colombianos desde a década de 1920. Arciniegas pode desempenhar esse papel de agitador, ativista ou empresário cultural, como tem sido já apontado pela historiografia, desde diferentes lugares da cultura letrada da capital colombiana. Como proprietário e diretor da editora Colômbia, diretor da revista Universidad, do Suplemento Literário do jornal El Tiempo e, por fim, da Revista de las Indias.

Arciniegas pediu, por exemplo, ao seu amigo Alberto Miramón que lhe encaminhasse seus livros, com o fim de apresentá-lo ao público portenho ${ }^{142}$. Miramón, autor de estudos sobre personagens da geração da independência da Colômbia ${ }^{143}$, era um antigo colaborador de Arciniegas na cátedra de sociologia da Faculdade de Direito da Universidade Nacional e era o secretário da Revista de las Indias, daí que Arciniegas lhe escrevera pedindo-lhe a coleção completa da publicação. Arciniegas escreveu também à revista de poesia Piedra y Cielo, considerando que com as revistas poderia informar sobre a produção colombiana do momento. Pediu às revistas coleções completas e números especiais preparados para a exposição, "QUE SERVIRÁN PARA ESTRECHAR RELACIONES CON LAS DE LA ARGENTINA". Arciniegas também escreveu ao poeta León de Greiff (1895-1976), de quem tinha publicado um texto na pequena editora Colômbia na década de 1920. Arciniegas pôs muito interesse em conseguir os livros de quem fora um dos poetas mais celebrados do país e que para surpresa sua, não era conhecido em Buenos Aires ${ }^{144}$. Da mesma forma, Arciniegas solicitou a Fabio Restrepo, diretor do jornal El Tiempo, álbuns com desenhos do chargista

\footnotetext{
${ }^{142}$ G.A. a Alberto Miramón, Buenos Aires, Enero 22, 1940, BNC, FGA, Caja 1, Carpeta 4.

143 Los septembrinos. Bogotá: A.B.C., 1939; Vida ardiente de Manuelita Sáenz. Bogotá: Librería Suramericana, 1944.

${ }^{144}$ G.A. a Luis Cabal, Buenos Aires, Mayo 15, 1940. BNC, FGA, Caja 1, Carpeta 4. "Ya recibí los libros de León de Greiff que me interesaban especialmente porque León no es conocido acá. Es una verdadera lástima que del primer Mamotreto no hubiera ningún ejemplar, aunque hubiera sido uno sólo para la muestra, pues hay allí algunos poemas que sn escenciales para una presentación correcta suya".
} 
Ricardo Rendón (1894-1931) ${ }^{145}$, que foi, junto com De Greiff, parte do movimento juvenil "Los Pánidas" de Medellín, e integrante de "Los Nuevos", um heterogêneo conjunto de escritores, críticos e artistas reunidos ao redor de uma pequena publicação homônima (de apenas 5 números), surgido nos cafés da bohemia bogotana da década de 1920 e ao qual é costumeiramente associado o próprio Arciniegas. A revista Universidad havia acolhido Rendón, entre outros jovens chargistas da década de $20^{146}$.

No Ministério de Relaciones Exteriores Arcineigas tinha dois bons colaboradores: Luis Eduardo Nieto Arteta e Luis Cabal, que fizeram envios de livros tirados de suas bibliotecas particulares. Cabal, escreveu assim relatando a movimentação gerada nos círculos bogotanos pela expectativa da exposição em Buenos Aires:

"te remití varios paquetes de libros de texto editados por la Librería Voluntad, los cuales me fueron obsequiados con tal fin por el gerente de esa casa, señor Arcadio Plazas.- Don Tomás Rueda Vargas me ha dicho que te ha hecho y continúa haciéndote muchos envíos.- Nuestro amigo Enrique Uribe White, de acuerdo conmigo, te enviará próximamente una colección de la revista "PAN", que actualmente estamos haciendo empastar para presentarla mejor, así como te debió llegar ya una colección empastada de la Revista Javeriana.-Monseñor Castro Silva me ha ofrecido una colección empastada, de los cuatro últimos años, de la Revista del Rosario (...) Me han traído Jorge Rojas y Carlos Martín varios paquetes de poesía "piedracielistas" dirigidos a ti y que mañana mismo te despacharé. Salvo una página magnífica de Jorge Zalamea, me parece que no se ha escrito todavía en Colombia ninguna crítica sensata y bien fundada sobre los poetas del grupo "Piedra y Cielo"147.

Arciniegas escreveu a outro escritor-diplomata, o jornalista Plínio Mendoza Neira, embaixador na Costa Rica e tempo depois na Venezuela, quem publicava com verbas da embaixada um Noticiario Colombiano e uma serie de Cuadernos del Noticiario Colombiano, dedicando cada número da série a um autor ou tendência literária contemporânea do país. Arciniegas procurou trabalhar junto com Plínio, o qual propôs "COMBINAR NUESTRAS EMPRESAS DE CULTURA". Arciniegas pediu a coleção completa das publicações da Embaixada, um número especial dos Cuadernos e uma coleção das publicações da editora Antena, propriedade de Mendoza Neira, prometendo dar aos materiais "LA MEJOR DISTRIBUCIÓN". Plinio e Arciniegas discutiram o conteúdo do número especial do Cuaderno, e escolheram uma antologia de poesia popular e não uma do pensamento político do liberalismo colombiano da nova geração (que já estava sendo organizada por Arciniegas) nem uma apresentação de poetas jovens, também em andamento nas

\footnotetext{
${ }^{145}$ G.A. a Fabio Restrepo, 17 de Junio de 1940.

${ }_{146}$ MEDINA, Álvaro. El arte colombiano en los años veinte y treinta. Bogotá, Colcultura, 1994, pp- 18-30.

${ }^{147}$ Luis Cabal a G.A, 20/04/1940, BNC, FGA, Caja 22, carpeta 28.
} 
editoras argentinas ${ }^{148}$. O volume escolhido, então, foi o de poesia popular, um campo no qual os intelectuais liberais trabalhavam com muito entusiasmo, como parte integral de sua política cultural que, segundo o historiador Renán Silva, estava orientada em duas direções: à expansão da cultura letrada e urbana e ao resgate do folclore das camadas populares, reconhecidas como base da cultura nacional ${ }^{149}$. Com efeito, Arciniegas tinha escrito o prólogo de um estudo sobre o folclore publicado nesses anos, estudo que iria ser incluso no caderno de Mendoza ${ }^{150}$.

Em carta a Teresita Santamaría, Arciniegas mencionou ter conseguido, depois de mais de um ano, quase 500 textos; o que lhe parecera, não entanto, insuficiente para abrir a mostra, pois o acervo constava apenas de produções literárias contemporâneas sem nenhuma peça de arte. Em missiva a Joaquin Tamayo, o escritor desabafou: "Todos mis esfuerzos tropezaron en la falta de colaboración de Bogotá para traer algunos libros antiguos que sirvieran de fondo a la producción nueva”. É possível então fazer algumas considerações sobre o fracasso do projeto. A primeira delas é que o tamanho e a qualidade da empreitada foram, afinal, obstáculos para a realização de uma mostra de livros colombianos na Argentina. Mas também que ambas as características do projeto respondiam a uma ideia de entendimento diplomático entre os países da região através da cultura, que nem sempre os outros diplomáticos enxergavam com clareza. A segunda consideração é que se bem Arciniegas e seus colaboradores planejaram oferecer uma síntese favorável da tradição cultural colombiana a um público estrangeiro, dificilmente pôde se falar num experimento de diplomacia cultural, toda vez que a participação do Ministério das Relações Exteriores foi fraca, e não se encontram na correspondência desses anos referências a

148 “NUMERO ESPECIAL DE TUS CUADERNOS. De los tres que me propones para escoger, creo que el de mayor interés acá sería el segundo, sobre poesía popular colombiana. La razón es esta: La antología de poetas jóvenes es muy posible que se haga acá, pues yo le escribí a (Eduardo) Carranza, y parece que tengo editor. El tomo del idearium liberal tendría mucho interés y es una gran idea, pero yo estoy preparando una presentación de Colombia con ensayos de Santos y otros, que tendría algo de ese libro. De modo que lo que es completamente distinto, y tiene aqui tal vez el mayor número de lectores es el cuaderno de poesía popular" Germán Arciniegas a Plinio Mendoza Neira, Buenos Aires, Febrero 16, 1940. Biblioteca Nacional de Colombia, Fondo Germán Arciniegas, Caja 1, Carpeta 4.

149 SILVA, Renán. República Liberal, intelectuales y cultura popular. La Carreta; BARRERA AGUILERA, Óscar Javier, "Folclor, indigenismo y mestizaje durante la República Liberal”, Maguaré, No. 23, 2009, pp. 133-153.

${ }^{150}$ Os diplomatas-escritores acordaram também fazer um volume dos Cuadernos, dedicado à obra de Arciniegas. 
uma possível dependência de cooperação intelectual, como existia em outros serviços diplomáticos da região para organizar exposições do tipo ${ }^{151}$.

Baste agora mencionar que existia entre alguns intelectuais colombianos a intenção de divulgar a cultura nacional país afora; embora as políticas culturais, dos regimes liberais relativas ao livro, estiveram até então mais voltadas para as populações populares do campo e das cidades, seja na forma de "Bibliotecas Aldeanas" localizadas em cidades pequenas e vilarejos - ainda muito afastados do centro do país -, que contaram em seus acervos com coleções oficiais selecionadas e distribuídas gratuitamente pela Biblioteca Nacional sob direção do escritor Daniel Samper Ortega; seja em feiras do livro com preços rebaixados. O planejamento de uma coleção de autores colombianos visando também sua distribuição no estrangeiro, a "Biblioteca Popular de Cultura Colombiana", teve que aguardar a chegada do próprio Arciniegas ao Ministério de Educação em $1941^{152}$.

A consciência das caraterísticas do projeto da exposição e da sua orfandade diplomática é eloquente na resposta de Arciniegas a Carlos Mario Puyo, que também preparava uma mostra de livros colombianos no Chile, em 1941:

"Mi Querido Carpuyo:

Acabo de recibir tu carta y te deseo toda suerte de éxitos en la Exposición del Libro Colombiano que se va a celebrar en Viña del Mar, pero me temo no poderte ayudar desde acá, porque los libros que tenemos para la exposición que se ha pospuesto para el año entrante son muy pocos y se estropearán en las andanzas de una exposición, donde es preciso que la gente pueda hojear y repasar los libros (...) Creo que has batido un record reuniendo los volúmenes de que me das cuenta en tu carta, pero si he de serte franco creo que con ellos no deberías hacer la exposición. Yo tengo aquí en realidad algo muchísimo mejor de lo que aparece en tu lista, y sin embargo no he querido presentarla por no dar una idea pobre de la producción colombiana. La presentación de memorias de los ministerios, de libros de autores extranjeros, de números sueltos de revistas y aún de ciertos libros de combate como el de Olarte Camacho sobre las crueldades de los peruanos, quizá no son lo más adecuado para estrechar relaciones entre los países de América y para exaltar nuestra producción literaria. Puesto en el mismo trance de celebrar una exposición del libro en Chile, García Peña acudió a un expediente más sencillo y eficaz, que consistió en solicitar de la Biblioteca Nacional de Chile los libros colombianos para presentarlos en la exposición, quizás esto podrías lograrlo con tu extraordinaria actividad. (...). "’153.

\footnotetext{
${ }^{151}$ Nesse sentido é interessante mencionar o caso de Gregorio Castañeda Aragón, diplomático colombiano na Guatemala que "había hecho allá publicaciones sobre Colombia, costeadas de su sueldo". Luis Cabal a G.A. 20/02/1943, BNC, FGA, Caja 22, Carpeta 28.

${ }^{152}$ SILVA, Renán. "Libros, lectores y lecturas en la República Liberal" e "Las Ferias del libro en Colombia", En: República liberal, intelectuales...Op. Cit.

${ }^{153}$ Germán Arciniegas a Carlos Mario Puyo, Buenos Aires, Diciembre 13, 1940. Biblioteca Nacional de Colombia, Fondo Germán Arciniegas, Caja 1, Carpeta 4
} 


\section{A estátua de Santander. Mediação e promoção do liberalismo colombiano.}

Uma terceira iniciativa diplomática que interessa comentar foi a instalação de uma estátua de Francisco de Paula Santander (1792-1840), uma das figuras heroicas do imaginário nacional colombiano, na cidade de Buenos Aires. A iniciativa se entrosava na comemoração do centenário da morte de Santander, que empreendeu o governo de Eduardo Santos decretando o ano de 1941 como o "ano Santander" e abrindo um concurso para premiar a melhor biografia original do prócer, figura tutelar do liberalismo no país ${ }^{154}$. Com efeito, boa parte do imaginário político do país tinha adotado a cisão entre os "dois pais da pátria", Simón Bolívar (1783-1830) e Francisco Santander; e desse modo, conservadores e liberais teriam adotado um ou outro como sua figura padroeira. Ataques e defesas, nunca absolutos, animaram as pequenas batalhas sobre a história pátria que estimularam as histórias de orientação partidária, nas quais o próprio Arciniegas tomou parte ativa ${ }^{155}$.

Os dois líderes foram as figuras mais salientes da campanha militar que ganhou o centro da Nova Granada para a causa da Independência da Espanha em agosto de 1819, e também da curta vida da República de Colômbia, conhecida na historiografia como a Grande Colômbia, até a secessão em c. 1830 do Equador e a Venezuela. Até 1827 Santander exerceu o governo como vicepresidente enquanto Bolívar continuava as campanhas militares no sul. No entanto, suas divergências marcaram o imaginário patriótico colombiano, associando-se o centralismo e o princípio da autoridade, representado na constituição de 1828, aos bolivarianos; e o princípio federal e a defesa da constituição de 1821 a Santander ${ }^{156}$. Mais tarde, os conservadores reclamaram a imagem de Bolívar, e os liberais identificar-se-iam com Santander.

Arciniegas investiu seus esforços na instalação de uma estátua de Santander na capital argentina, visando aproximar o público local à imagem desse herói que sendo nacional era, sobretudo,

${ }^{154}$ O concurso foi ganho pelo escritor José Antônio Lizarazo com El fundador civil de la República. Bogotá: Editorial del Comercio, 1940. Osorio era colaborador de Arciniegas na Revista de las Indias, que também teve parte nas comemorações com um número dedicado a Santander.

155 Melo, Jorge Orlando. "La literatura histórica en la Republica". Em: Historiografia colombiana. Realidades y perspectivas. Bogotá: Autores Antioqueños. 1996. Uma resposta desde o Partido Conservador foram os artigos de jornal de 1940, coletados em: Gómez, Laureano. El mito de Santander. Bogotá: Editora Revista Colombiana. 1966. Gómez era uma das principais figuras do Partido Conservador, o opositor mais febril dos governos liberais.

156 Melo, Jorge Orlando. "Bolívar en Colombia: conservador y revolucionario". Disponible en: http://www.jorgeorlandomelo.com/bolivarcolombia.htm 
partidário. Tratava-se então de dar visibilidade sobre determinada tradição política colombiana. Em cartas ao presidente Santos, Arciniegas informou dos avanços do projeto que teve que passar pelo Senado e a Câmara de Deputados, além de ter sido considerado pelas autoridades locais da cidade. No processo, o embaixador Urdaneta e Arciniegas contaram com a participação ativa de Martín Noel, deputado que lhe ofereceu seu apoio na Câmara, e do gral. Justo, quem discursou na cerimônia de instalação. Sobre Justo já tem se mencionado seu interesse pela história colombiana, e particularmente o pedido de livros antigos, entre os quais uma parte editada do arquivo de Santander. Já Noel, arquiteto e historiador da arquitetura, principalmente do período colonial, tinha justamente nessa atividade uma grande afinidade com o escritor-diplomata colombiano. Em duas cartas conservadas no acervo de Arciniegas, o colombiano faz menção dos livros do argentino, da sua ideia a respeito do aparecimento de uma arquitetura hispano-americana singular, e lhe encaminha o catálogo da projetada exposição do livro e a arte colombiana. Em artigos publicados por Arciniegas no Suplemento Literário de La Nación, em Buenos Aires, chegou fazer menção das teorias de Noel. Mas nas ditas cartas se informa também que Arciniegas encaminhou a Noel livros e informações avulsas acerca de Santander, para que ele pudesse intervir na Câmara a favor do projeto. Por fim, valha dizer que Noel era também, um dos membros fundadores da Associação Amigos da Arte.

A instalação não foi uma iniciativa isolada. Quando da hora da instalação, escreveu a Santos solicitando uma mensagem sua com o intuito de contar com a resposta do vice-presidente Castillo, da Argentina, na cerimônia. O gesto iria apenas reproduzir o que já tinha sido feito em Bogotá na instalação da estátua de San Martín, com a troca de mensagens entre os presidentes López e Ortiz. Finalmente o intendente de Buenos Aires teria indicado um espaço no Rosedal, nos Bosques de Palermo, para a instalação do monumento que ainda hoje se encontra no local.

Arciniegas pôde colaborar de outras formas para o conhecimento de Santander nos meios argentinos. O escritor publicou o artigo "Santander o el nacimiento de la consciencia civil en América” no jornal La Prensa, em 5/05/1940; e em julho apareceu na Revista de las Indias seu discurso de apresentação como membro correspondente na Academia Nacional da História em Buenos Aires, "Santander y la lucha por la libertad después de la independência”, texto que foi publicado nos anais da Academia no ano seguinte. Ambos os textos compartilham vários tópicos, 
mas têm também diferenças. A maior delas, o fato de o discurso na Academia Nacional da História ter um foco nas relações diplomáticas da Colômbia e da Argentina, enfatizando a perspectiva continental que norteou a política dos dois países no período pós-independência da Espanha. Já o artigo de La Prensa começava resgatando um dos argumentos centrais à obra ensaística de Arciniegas, defendido desde o seu primeiro livro El estudiante de la mesa redonda: o papel de vanguarda dos estudantes no movimentos históricos ${ }^{157}$.

Mas são outros aspectos desses textos o que interessa destacar. Arciniegas retomou um segundo tópico do seu primeiro livro, presente em outras das suas obras posteriores como América: Tierra firme: a oposição entre os homens de letras e os homens de armas, que o escritor identifica já na conquista espanhola do território americano. Um binarismo que coloca em cotejo figuras como o conquistador Gonzalo Jiménez de Quesada ${ }^{158}$, a quem se considera fundador de Bogotá e que era homem de letras, com Francisco Pizarro, homem de origem humilde, analfabeto, filho de criadores de porcos. O cotejo se desdobrava entre figuras como os próprios Bolívar e Santander, educados, com conhecimento de outras línguas, em contraste com figuras como José Antônio Paez, caudilho dos pampas venezuelanos. Santander pôde ser incluído e ser destacado entre os heróis da tradição civil do continente, pois conseguiu impor seu mando sobre o conjunto de generais vitoriosos para organizar a república, enquanto O Libertador continuava a sua campanha no Peru:

"Cuando él surge como una gran figura americana, cuando su obra es genial y atrevida, es en el momento en que sobreponiéndose al placer de la victoria y a la inquietud moceril, le pide a los militares triunfadores que se inclinen debajo de la ley. Él vió claro que la guerra no se encaminaba a la simple independencia política de España, sino a procurar la libertad de los colombianos, y tembló horrorizado ante la perspectiva de que la república se convirtiera en feudo de los militares".

No elogio do Santander, Arciniegas se ecoava da conciliação entre as armas e as letras comum à retórica da glorificação dos heróis na Colômbia ${ }^{159}$, e na qual se bem podiam ser contemplados os

157 "En Colombia, como en toda América, la guerra de emancipación fue empresa de la juventud. Quienes primero anunciaron la revuelta fueron los estudiantes", "formalizada la guerra se vieron siempre a la cabeza de ejércitos de campesinos muchachos de 20 años", "Esta jornada iba a ser tan audaz, tan absurda y tan heroica, que sólo la juventud podía concebirla y realizarla". "Santander o el nacimiento de la consciencia civil en América". La Prensa, 05/05/1940.

158 O livro de Arciniegas, Jiménez de Quesada. Bogotá: A.B.C., 1938, apareceu em meio às comemorações pelo centenário da fundação da cidade.

159 Tovar Zambrano, Bernardo. "Porque los muertos mandan. El imaginario patriótico de la historia colombiana". Em: Ortiz, Carlos Miguel \& Tovar Zambrano, Bernardo. Pensar el pasado. Bogotá: Universidad Nacional de Colombia, 1997. p. 125-169 
dos pais da pátria, O Libertador e o Homem das Leis, seria esse último, Santander, o herói predileto para quem se interessa na defesa dos governos de cunho liberal, civis e temperados ${ }^{160}$. E é a partir dessa dupla dimensão das armas e as letras que Arciniegas eleva o general à condição de herói americano, realizando várias comparações com figuras centrais do panteão nacional argentino. Como o San Martín de Ricardo Rojas, sobre Santander "gravita un mandato moral; por eso su figura de héroe militar se proyecta en una figura de héroe civil. Más hermosa que su hazaña es su conciencia" 161 . Mas também compartilhar o fato de serem, além de guerreiros e homens de letras, grandes administradores, na organização financeira dos novos estados de Colômbia e Perú ${ }^{162}$. Já junto a Mariano Moreno, “convienen en que el único sentido de estas luchas es la conquista de la libertad"163, consideração que também o aproxima do Dean Funes $^{164}$. Já Santander tinha empreendido, quase cinquenta anos antes de Sarmiento, a expansão da educação pública, o recomeço das expedições científicas, a fundação de um museu e de uma universidade, fazendo com que a Colômbia fosse "una república ilustrada" 165.

Por outro lado, através da figura de Santander, Arciniegas transmitia uma imagem da Colômbia como de um país republicano onde o liberalismo tinha estabelecido suas raízes firmemente. Santander realizou uma obra de governo baseada no "Acompasado ritmo de la paz", defendendo o repouso e a ordem sob o império das leis, se opondo tanto ao despotismo quanto à anarquia ${ }^{166}$. Santander "simboliza la rebeldía de los demócratas contra la dictadura"167, manifesta dramaticamente no atentado contra a vida de Bolívar cometido em Bogotá por um grupo de jovens estudantes partidários de Santander quando O Libertador, de regresso à Colômbia após o fim da campanha do sul, tentava impor uma nova constituição que contemplava a Presidência e o

${ }^{160}$ É importante mencionar que nos anos 1930, os jovens conservadores radicalizados para o fascismo erigiram a Bolívar como símbolo da renovação de seu partido, reatualizando a divisão partidária do imaginário patriótico, como o fizeram Arciniegas e seus colegas liberais com Santander. Ayala Diago, César Augusto. "La tradición también influye. Remozamiento político e ideológico de la derecha colombiana en los años treinta". Em: Acosta, Carmen Elisa et. Al. Independencia, independências y espacios culturales. Bogotá: Universidad Nacional de Colombia. 2009. Os jovens conservadores conhecidos como os Leopardos, além de coetâneos de Arciniegas tinham compartilhado com ele a intensa vida intelectual dos anos 1920, militado juntos a favor da Reforma Universitária e colaborado nas páginas da revista Universidad. Arias, Ricardo. Los leopardos...Op. Cit.

${ }^{161}$ Ibíd.

162 "Santander y la lucha por la libertad después de la independencia". Boletín de la Academia Nacional de la Historia. Vo. XIV. Buenos Airez, 1941, pp 163-179.

163 "Santander o el nacimiento..."

164 "Santander y la lucha..."

165 "Santander o el nacimiento..."

166 "Santander y la lucha..."

${ }^{167}$ Ibíd. 
Senado vitalícios, entre outras medidas. Para Arciniegas o episódio "fijó un destino en la vida colombiana. Si el pueblo se atrevía contra Bolívar, contra el padre de la patria, contra el Libertador, ya nadie más podría aventurarse allí por los caminos de la dictadura. Y por eso no ha habido dictaduras en Colombia.". Colômbia, afirmou, "debe ser la nación de América donde ha habido mayor número de gobernantes" ${ }^{168}$.

A chave da explicação dessa singularidade colombiana que o escritor projetava sobre o cenário argentino, como expressão de um nacionalismo encenado para o estrangeiro, radicaria no "clima moral" da capital, Bogotá169. Segundo Arciniegas "No se podría explicar a Santander sin colocarle como telón de fondo a Bogotá". Para o escritor "el espíritu de la ciudad, fría y poco luminosa, que a los pocos años de fundada tenía ya varias universidades", e que "no obstante unos minúsculos combates librados en sus ejidos o en sus propias calles, ha sido la ciudad menos guerrera del mundo", induziu nos governantes o estilo civil e moderado ${ }^{170}$, que eles conseguiram impor no país todo: "Viendo así las cosas, Santander resulta una interpretación perfecta del carácter bogotano, del carácter que la capital impuso al país y que ha venido a ser rasgo distintivo de la democracia colombiana"171. A influencia de Santander "en la constitución moral de Colombia, fue definitiva" ${ }^{172}$, afirmava Arciniegas ${ }^{173}$.

Essa associação da nação colombiana ao legado legalista e moderado de Santander era condizente com os posicionamentos do presidente Eduardo Santos. No Elogio del general Santander, discurso pronunciado em1940, Santos proclamava que Santander:

\footnotetext{
168 "Santander o el nacimiento..."

${ }^{169}$ Para Arciniegas, Santander teria construído sua doutrina apenas a partir da observação dos almejos libertários do povo. Assim, prefigurava a função da capital, cabeça de um corpo nacional no qual "su cerebro tiene que recoger las sensaciones que llegan de la provincia remota". "Santander y la lucha...".

170 "Es cuestión de ambiente. Si los bogotanos han entrado en las guerras civiles, han hecho el héroe en silencio, sin ostentación, y llegados a los términos de la paz encuentran demasiado ostentoso el uniforme, estridente el brillo militar, y se acogen a la luz de Santa Fe, que es una luz tranquila”. "Santander o el nacimiento...".

171 Para Arciniegas, as nove guerras civis nacionais que sofreu o país no século XIX, foram as guerras de independência, "no iban tras ningún encumbramiento militar. Eran pronunciamientos en que se empeñaban los partidarios de un cambio constitucional". Ibíd.

172 “Santander y la lucha...". Op. Cit.

173 Bogotá, no entanto, foi uma cidade que experimentou intensos levantamentos durante o século XIX, protagonizados pelos artesãos que colocaram em xeque aos governos do momento. Aguilera Peña, Mario, Insurgencia urbana em Bogotá. Bogotá. Colcultura. 1997; Sowell, David. Artesanos y política en Bogotá. Bogotá. Pensamiento Crítico. 2006.
} 
"interpretando con instinto misterioso lo que reclamaba la nación colombiana, modeló esta alma cívica nuestra que cree mas en las ideas que en los hombres; que confía un mandato a sus gobernantes pero no se pone ciegamente en sus manos; que hace de la Constitución y la ley las rutas por donde debe avanzar hacia el porvenir, lenta o rápidamente, pero siempre al amparo de la libertad y el decoro"'174

Para Santos, Santander era "el más grande de nuestros compatriotas", o "prócer exímio" da Colômbia, oposto ao despotismo e à anarquia, que "abomina a la vez de la demagogia y de la arbitrariedade" e prefere, para aliviar a miséria do povo, "los remedios a largo plazo, lentos, sin duda, pero eficaces", decorrentes de uma transformação moral da nação pela via da educação, da imprensa e do bom exemplo dos governantes. Para Santander, continuava Santos, a primeira necessidade das nações americanas eram repouso e ordem ${ }^{175}$.

Finalmente, Arciniegas destacou o caráter continental da perspectiva política de Santander, na defesa da independência e dos princípios republicanos. No discurso da Academia, relatou a primeira campanha diplomática da Colômbia, que liderada por Joaquin Mosquera rendeu acordos de defesa comum com o Peru e a Argentina. Santander também teria oferecido seus serviços militares ao México. Por isso "Es el hombre que en América encarna el espíritu civil”, e "simboliza un precoz apego a los principios civiles que habian de iniciar a los pueblos independientes en la vida de los pueblos libres", que ainda devem ser mantidos: "Por los senderos que él abrió en la mañana de una república virginal, todavía y mientras tengamos amor a la libertad, seguimos y seguiremos encaminando nuestros pasos”.

Liderança letrada, unidade continental, moderação. Valores que, citando ao presidente Eduardo Santos, Arciniegas defendia com ironia, chamando-os de "pequeno-burgueses"176. Nessa tomada

\footnotetext{
174 Santos, Eduardo. "Elogio del general Santander". Em: Etapas de la vida colombiana. Discursos (1938-1942). Bogotá: Ministerio de Educación. 1946. p. 168. Outros aspectos do Elogio aparecem nos textos de Arciniegas: a condição de estudante antes da guerra de independência, a submissão dos militares ao poder civil e o caráter americano do pensamento do herói, além da necessidade da união continental proclamada por ele. Segundo Eduardo Posada Carbó, a reativação do santanderismo no pensamento político colombiano foi responsabilidade de Santos já na década de 1910, quando da polêmica desatada pelo venezuelano Laureano Vallenilla Lanz em seu Cesarismo Democrático, uma proposta de governo forte ligada à defesa do regime de José Vicente Gómez. Posada Carbó, Eduardo. "Colombia en Cesarismo Democrático". Em: Carrera Damas, Germán. Mitos políticos en las sociedades andinos. Orígenes, invenciones, ficciones. Lima: IFEA, Editorial Equinoccio, 1996. p. 266. A importância da polêmica para o liberalismo nacional já tinha sido destacada por Molina, Gerardo. Las ideas liberales en Colombia. V.II. 1915-1934. Bogotá: Tercer Mundo, 1974.

${ }^{175}$ Santos, Eduardo, Etapas de la vida colombiana. Discursos (1938-1942). Bogotá. Ministerio de Educación. 1946, pp 103-118.

${ }^{176}$ Arciniegas citava um trecho do Elogio del General Santander.
} 
de posição, assinalava uma distância não apenas diante dos poderes militares, mas também das lideranças civis que construíam na década de 1940, apoios populares ancorados em retóricas de confrontação social, distorcendo o clima calmo da república, principalmente da capital ${ }^{177}$.

Nos anos seguintes, o escritor pode retomar a promoção do herói colombiano nos meios argentinos. Na revista Sur, fez pequenas defesas da imagem do general Santander em comentários às biografias de Simón Bolívar redigidas por Salvador de Madariaga e Waldo Frank. Já na década de 1950, ao explicar "como se destrói uma democracia", em seu livro Entre la libertad y el miedo, o escritor voltaria sobre a herança liberal do herói, suas semelhanças com Sarmiento e a confrontação entre homens de letras e homens de armas. Nessa década também chegaria a oferecer em Buenos Aires palestra sobre os "heróis civis da América Latina".

\section{Tratados comerciais. A integração americana.}

Como Encarregado de Negócios, na ausência dos embaixadores Urdaneta e Caballero ${ }^{178}$, Arciniegas teve que escrever informes acerca da política interna argentina e continuar as negociações do tratado comercial começadas por Urdaneta e pelo cônsul Ignácio Pombo no primeiro semestre de 1940. Arciniegas, nesse último aspecto, limitou-se a apresentar às autoridades argentinas projetos de artigos a serem inclusos no tratado, sem intervir nas negociações nem na redação deles, se comportando apenas como um canal entre o Ministério de Relações Exteriores colombiano e os negociadores argentinos ${ }^{179}$.

\footnotetext{
177 Véase BRAUN, Herbert. Mataron a Gaitán. Vida pública y violência urbana em Colombia. Bogotá. Punto de Lectura, 2013.

${ }^{178}$ Urdaneta chegou à Argentina depois de ter representado a Colômbia nas negociações da paz com o Perú. Caballero, depois de representar o país na negociação sobre limites territoriais com a Venezuela. Arciniegas havia defendido essas negociações na grande imprensa liberal portenha: "APENAS SI SE DARÁN CUENTA HOY EN AMÉRICA DEL BIEN INMENSO QUE REPRESENTA PARA LAS GENERACIONES FUTURAS LLEGAR A ACUERDOS COMO EL QUE SE HA HECHO CON VENEZUELA, VIENDO LO QUE ES LA PAZ TENIENDO EN CUENTA EL CATACLISMO DE EUROPA (...) LE ENVÍO RECORTES DE LO QUE SE HA PUBLICADO HOY AQUÍ. YO ESCRIBÍ UN MEMORANDUM HACIENDO UNA BREVE HISTORIA DE LO QUE HABÍA SIDO LA CUESTIÓN DE LÍMITES CON VENEZUELA, QUE ENVIÉ A TODOS LOS PERIÓDICOS. EN ESE MEMORÁNDUM SE BASA UN POCO EL ARTÍCULO DE "LA PRENSA". TAMBIÉN LE ENVÍO EL RECORTE DE UN ARTÍCULO QUE PUBLIQUÉ EN "LA NACIÓN" G.A. a Eduardo Santos, Buenos Aires, Abril 5,1941. BNC, FGA, Caja 1, Carpeta 5.

${ }^{179}$ G.A. a Rafael Urdaneta, Buenos Aires, Agosto 09, 1940. BNC, FGA, Caja 1, Carpeta 4.
} 
Todavia, uma nova iniciativa do governo argentino em matéria de intercâmbio comercial deu a Arciniegas a possibilidade de se mostrar mais ativo. Em carta a Urdaneta em agosto de 1940 informava sobre a criação de “UNA COMISIÓN PARA EL ESTUDIO DE LAS RELACIONES CON LOS DEMÁS PAÍSES DE AMÉRICA" ${ }^{180}$ e sobre as intervenções que ele mesmo tinha realizado para conseguir do Ministério de Relações Exteriores informes sobre produtos colombianos, solicitados pela comissão. Sobre a comissão escreveu a Santos alguns dias depois:

"EL PRESIDENTE ES DON ALFONSO HOLMBERG, MUY BUEN AMIGO DE COLOMBIA, Y MÍO, DE TAL SUERTE QUE ÉL ME HA VENIDO ENTERANDO DE TODOS LOS PROPÓSITOS DE LA COMISIÓN Y PIDIÉNDOME DATOS SOBRE LOS PRODUCTOS COLOMBIANO QUE PODRÍAN VENDERSE ACÁ. COMO MUCHAS OTRAS PERSONAS, Y COMO CASI TODOS LOS NORTEAMERICANOS QUE HAN PASADO ESTOS DIAS POR BUENOS AIRES, HOLMBERG PIENSA QUE PARA HACER UNA POLÍTICA CONTINENTAL COLOMBIA ES HOY TAN NECESARIA COMO ARGENTINA Y ESTADOS UNIDOS, POR EL DESARROLLO QUE ESTÁ TOMANDO EL PÁIS Y POR SU ORIENTACIÓN POLÍTICA. ADEMÁS, COMO PUNTO MEDIO ENTRE LAS AMÉRICAS DEL NORTE Y DEL SUR. SI LA COMISIÓN TOMA AQUÍ ALGÚN VUELO, CREO QUE VALDRÍA LA PENA DE FORMAR EN BOGOTÁ ALGO PARECIDO QUE ESTUDIARA DESDE EL PUNTO DE VISTA NUESTRO EL MISMO PROBLEMA"181.

Se por um lado, podemos destacar de novo a importância dos vínculos pessoais para o trabalho diplomático, são outros dois aspectos que nos interessa aprofundar para dar um contexto apropriado às atividades de Arciniegas. Em primeiro lugar, o comércio entre Argentina e Colômbia, que praticamente inexistia no período. Além dos vizinhos mais próximos, especialmente o Brasil, a Argentina não mantinha um comércio fluido com outros países da região. Em segundo lugar, que a empreitada de fortalecê-lo tinha um sentido amplo, além da economia, atrelado, como sugeria Arciniegas, à construção de uma "política continental"182. Essa construção foi um dos principais pontos na agenda das nações americanas durante esses anos, marcados pela II Guerra Mundial.

A conflitante construção do sistema pan-americano consolidado nesse mesmo período teve na Argentina a voz mais dissonante. O país do sul, fiel à sua tradição internacional que o vinculava estreitamente aos mercados europeus, assim como de confronto e desconfiança perante os Estados Unidos, se opôs às iniciativas que durante vários anos foram se debatendo e, em muitos casos, se adotando a favor de uma política de defesa comum ${ }^{183}$. A atitude da Argentina favorecia

\footnotetext{
${ }^{180}$ G.A. a Rafael Urdaneta, Buenos Aires, Agosto 13, 1940. BNC, FGA, Caja 1, Carpeta 4.

${ }^{181}$ G.A. a Eduardo Santos, Buenos Aires, Agosto 20, 1940. BNC, FGA, Caja 1, Carpeta 4.

182 DEL RÍO...Op. Cit. Pp. 91.

183 SUÁREZ SALAZAR, Luis y GARCÍA, Tania, Las relaciones interamericanas: continuidades y cambios. Buenos Aires. CLACSO, 2008.
} 
mais a perspectiva da integração econômica do que a política, tanto mais quanto essa última representava adotar uma atitude única diante do conflito, seja a neutralidade, a não beligerância ou guerra; e com isso arriscar os mercados do velho continente. Além disso, era claro que amplos setores do país simpatizavam com as ideologias e os sistemas de governo agrupadas no eixo, o que tornou ainda mais difíceis as relações com os Estados Unidos e seus aliados mais fieis, como era o caso da Colômbia.

É por isso que no comentário de Arciniegas não é surpreendente a presença de personagens e opiniões norte-americanas -assim como a do próprio Holmberg - sobre a importância da Colômbia na cena regional. No processo de criação do sistema pan-americano, a Colômbia costumou se mostrar sempre favorável aos projetos de coordenação da defesa regional propostos pelos Estados Unidos, e propôs repetidas vezes a formação de uma "Liga das nações americanas" ${ }^{184}$. Por isso, na década de 1990, Arciniegas sublinha o clima hostil que encontrou em alguns círculos oficiais argentinos ${ }^{185}$.

O desembarque de Arciniegas na Argentina, pela via marítima, esteve marcado pelas vicissitudes da guerra. Durante a viagem do Rio de Janeiro a Buenos Aires teve lugar a chamada "Batalha do Rio da Prata", com o afundamento, por parte das forças britânicas do navio alemão Almiral Graf Spee, que tinha sido fundamental nas estratégias atlânticas do exército nazista. Por outro lado, não apenas os grupos conservadores apoiavam a política de neutralidade. A opinião pública liberal mostrou-se também contrária ao abandono da neutralidade e à sua substituição pela não beligerância, mesmo quando o próprio governo argentino o propôs, em junho de 1941, como consequência da mencionada "Batalha do Rio da Prata". A neutralidade não foi colocada em dúvida nem mesmo pelos grupos liberais, até janeiro de $1942^{186}$, quando Arciniegas já estava em Bogotá como Ministro da Educação.

\footnotetext{
184 Já foi afirmado que houve polarização entre duas tendências no contexto latino-americano. Um lado proestadunidense, liderado pela Colômbia, e um anti-norteamericano, representado pela Argentina. TORRES DEL RÍO, César. "Siglo XX: relaciones y políticas" En: Asociación Argentina de Colombia, Argentinos y colombianos. Historias y encuentros. Bogotá. La Asociación, 1994, pp, 62-157. Sobre a política pro norteamericana de Santos véase BUSHNELL, David, Eduardo Santos y la política del Buen Vecino. Bogotá. El Áncora Editores, 1984

185 "Buenos Aires era fundamentalmente francófila y el gobierno germanófilo". CACÚA...Op. Cit.

${ }^{186}$ SENKMAN...Op. Cit.
} 
Arciniegas divulgou e defendeu a política exterior de Santos, entregando em alguns círculos portenhos - de argentinos, espanhóis ${ }^{187}$ e norte-americanos ${ }^{188}$ - as mensagens que Santos dirigia ao Congresso Nacional e as outras nações. Arciniegas também divulgou suas preocupações em entrevistas na imprensa argentina ${ }^{189}$.

Arciniegas também reclamava das informações desfavoráveis que a imprensa publicava a esse respeito e também informava a Santos sobre o desempenho no mesmo sentido do embaixador Urdaneta. Isso ficou ainda mais claro depois que o chanceler colombiano Luís López de Mesa (1884-1967) - um dos escritores mais prestigiosos na Colômbia do começo do século XX propôs entre outras coisas a criação de uma zona de segurança que deixava a zona do canal de Panamá como área de soberania compartilhada e a abertura de todas as bases navais e aéreas a todos os países americanos, ou seja, principalmente aos Estados Unidos. López de Mesa dirigiu uma circular secreta às legações colombianas no continente, inquirindo-as sobre as possibilidades de promover essa proposta que, como era previsível, não era bem recebida nos meios oficiais argentinos. Assim o fez saber Urdaneta a Lopez de Mesa ${ }^{190}$. Arciniegas escreveu a Santos para

\footnotetext{
187 Sobre os espanhóis, escreveu a Santos: "NO PUEDE SUPONER USTED EL CARIÑO QUE LE TIENEN" G.A. a Eduardo Santos, Buenos Aires, Agosto 20 de 1940, BNC, FGA, Caja 1, Carpeta 4. Santos foi solidário com a causa republicana e realizou ações sigilosas a favor de alguns exilados, em algumas das quais Arciniegas agiu como ponte entre o governo e, por exemplo, Juan Antonio Irazusta, José María Ots Capdequí e Domingo Casanovas. Ver: GA a Juan Antonio Irazusta, 05/12/1938; GA a Domingo Casanovas, 07/12/ 1938; GA a Alfonso Araújo, 07/12/1938 Biblioteca Nacional de Colombia, Fondo Germán Arciniegas, Caja 1, Carpeta 2; y GA a Domingo Casanovas, 26/01/1939. Biblioteca Nacional de Colombia, Fondo Germán Arciniegas, Caja 1, Carpeta 3. Sobre as relações do governo Santos e os republicanos espanhóis: BUSHNELL, David, "La guerra civil española, $1936-1939$. Perspectivas colombianas" Em: Ensayos de historia política de colombia, siglos XIX y XX. Bogotá, La Carreta. 2006 e HERNÁNDEZ GARCÍA, José Ángel. La guerra civil española y colombia. Influencia del principal conflito mundial de entreguerras em Colombia. Bogotá. Universidad de La Sabana. Editorial Carrera 7ma. 2006. Um dos espanhóis mais próximos a Arciniegas em Buenos Aires foi Ángel Osorio y Gallardo, embaixador da república espanhola na Argentina, que era colaborador da Revista de las Indias. Arciniegas lembrou que Osorio o aconselhava em matérias oficiais e a solidariedade entre eles foi manifesta na divulgação que o espanhol fez das mensagens de Santos. G.A. a Eduardo Santos, Buenos Aires, Agosto 23 de 1940, BNC, FGA, Caja 1, Carpeta 4.

188 Arciniegas mencionou ter distribuido a messagem para Hubert Clinton Herring, quem estaba "AL FRENTE DE UNA MISIÓN DE ESCRITORES Y PROFESORES NORTEAMERICANOS” além de "COLABORADOR DE LAS REVISTAS AMERICANAS MÁS CALIFICADAS” e a Samuel Guy Inman, quem jà tinha visitado Bogotá gestionando o ingresso de alguns refugiados do nazismo. G.A. a Eduardo Santos, Buenos Aires, Agosto 20 de 1940, BNC, FGA, Caja 1, Carpeta 4.

189 "No existe un nuevo orden sino una nueva orden nazi”. Entrevista con Agustín Ferraris. Hombre de América. Ano II, Vol. 9, abril de 1941. pp. 8-9.
}

190 DEL RIO...Op. Cit. p. 89. 
lhe contar acerca do recibo dessa circular, sugerindo que a atuação de López ia além do que Santos defendia e reconhecendo neste caso a probidade de Urdaneta ${ }^{191}$.

Urdaneta e Arciniegas receberam López de Mesa em Buenos Aires, em visita oficial. O chanceler e escritor levou elogios para "su talento y su cultura", e Arciniegas organizou um encontro entre ele e alguns escritores argentinos, "fuera de las fiestas del protocolo" 192. Ali, como era de se esperar, López foi inquirido pelos jornalistas locais. Para confundir mais um pouco a situação, as declarações do ex-presidente Alfonso López Pumarejo em Buenos Aires embaçaram as opiniões sobre a posição oficial do país. Alarmado pela dimensão que tomava o assunto, Santos deu as próprias declarações à imprensa portenha ${ }^{193}$.

Por outro lado, a diplomacia colombiana também propôs um projeto de integração econômica que, embora não fosse acolhido, teve uma boa recepção nos círculos diplomáticos argentinos interessados em explorar os mercados continentais. Com efeito, nesses anos a Argentina assinou tratados comerciais bilaterais com vários países, entre eles a Colômbia, o que indica o crescente interesse nessa integração e uma mudança prudente de perspectiva perante a conflagração europeia $^{194}$. Voltando à carta de Arciniegas sobre a comissão de comércio, o escritor continuava mencionando a “OFERTA QUE ALGUNAS EMPRESAS NORTEAMERICANAS HAN HECHO DE VENTA DE BARCOS PARA UNA MARINA MERCANTE CUYO RECORRIDO LIGARÍA A LA ARGENTINA CON LOS PAÍSES DEL LADO DEL ATLÁNTICO, HASTA MÉXICO”. O escritor enfatizou para o presidente o promissório da proposta: “COMO USTED VÉ, SI NOSOTROS SEGUIMOS DESDE SU PRINCIPIO LOS DESARROLLOS DE ESTA IDEA, Y PARTICIPAMOS INDIRECTAMENTE EN LOS DEBATES APROVECHANDO AL SEÑOR HOLMBERG, QUIZÁS ASEGUREMOS PARA EL PAÍS UNA NUEVA Y MAGNÍFICA SITUACIÓN"'195.

Um fator decisivo para o fracasso de alguns projetos de intercâmbio comercial entre os países latino-americanos, desde a década de 1920, foi a falta de um barco que conectasse o litoral

191 Sobre a correspondência entre Urdaneta e López de Mesa, TORRES DEL RÍO...Op. Cit. "CREO QUE EL DOCTOR URDANETA ES HOMBRE MUY DISCRETO Y LEAL". G.A. a Eduardo Santos, Buenos Aires, Diciembre 13 de 1940, BNC, FGA, Caja 1, carpeta 4. Para enfatizar mais um pouco o clima de intimidade que existía entre os escritores-funcionários públicos colombianos da República Liberal, podemos mencionar que López de Mesa se referia à mãe de Germán Arciniegas como "la simpática parlanchina". López de Mesa a G.A., 06/05/1939. BNC, FGA, Caja 22, Carpeta 28.

${ }^{192}$ G.A. a Eduardo Santos, Buenos Aires, Octubre 8 de 1941, BNC, FGA, Caja 1, Carpeta 5.

${ }^{193}$ G.A. a Eduardo Santos, Buenos Aires, Marzo 7 de 1941, BNC, FGA, Caja 1, Carpeta 5.

194 PARADISO, José, Debates y trayectoria de la política exterior argentina. Buenos Aires, Grupo Editor Latinoamericano, 1993. TORRES DEL RÍO...Op. Cit.

${ }^{195}$ G.A. a Eduardo Santos, Buenos Aires, Agosto 20, 1940. BNC, FGA, Caja 1, Carpeta 4. 
atlântico da Argentina até o México, encadeando na rota outros países. Nessa história, a pressão dos Estados Unidos no intuito de falir as negociações adiantadas para conseguir o navio, foi decisiva ${ }^{196}$, o que indicava justamente que as orientações de integração tinham sido divergentes há tempos. O fato é que as relações comerciais entre Colômbia e Argentina eram sumamente tímidas. Arciniegas, solícito como outros escritores diplomatas na Argentina ${ }^{197}$, buscava promovê-las mais um pouco, principalmente para "DARLE MAYOR ENTRADA AL CAFÉ SUAVE, QUE APENAS SI SE USA MUY DEBILMENTE HOY EN LAS MEZCLAS ARGENTINAS, NO OBSTANTE EL ENORME CONSUMO QUE SE TIENE DE CAFÉ,198

Dias depois, Arciniegas dirigia a Homberg um estudo sobre o café colombiano e assinalava algumas possibilidades de comércio binacional. Aproveitando o desenvolvimento das negociações com outros países, indicou a "posibilidad argentina de exportar seda rayón para las fábricas que trabajan con esa seda en Colombia”, e que a comissão brasileira para o estudo do comércio com a Colômbia tinha manifestado interesse por "carbón, petróleo, fique y sombreros de jipa" 199 .

Finalmente, houve um incidente comercial com desdobramentos sobre a política de defesa continental bastante curioso. Às margens das iniciativas oficiais, um comerciante argentino entrou em contato com Arciniegas com o propósito de obter informações sobre a extração de platina na Colômbia, e as possibilidades para importá-la. Arciniegas estabeleceu contatos entre ele e alguns empresários nacionais. Mas depois recebeu informações sobre o empreendedor que o acusavam de agir como ponte entre os mercados latino-americanos e o governo alemão, tendo como base a Argentina, para comprar grandes quantidades de platina para fins bélicos. Arciniegas, em cartas aos empresários colombianos e ao próprio Santos, alertou sobre os perigos desse comércio e procurou, com sucesso, deter as transações.

196 YANKELEVICH...Op. Cit.

197 Se as missões diplomáticas lideradas por escritores "conducían a un mayor acercamiento entre los países de América Latina en términos culturales e intelectuales, no se puede decir lo mismo en lo que se refiere a las relaciones específicamente económicas y políticas". CRESPO, Regina Aída, "Entre porteños y cariocas. Alfonso Reyes embajador", $\quad$ consultado el 30/11/2012 en: http://cvc.cervantes.es/literatura/escritores/a reyes/entorno/crespo.htm. Os ecritores foram solícitos funcionários na busca da integração comercial, mas seu sucesso foi muito limitado. A presença de escritores na diplomacia podia então ser enxergada duma forma pessimista, seguindo as palavras do escritor argentino Leopoldo Lugones: “Cuando dos repúblicas de América no tienen nada que intercambiarse, nada que vender, nada que comprar, lo mejor que pueden hacer es enviarse mutuamente poetas"197. YANKELEVICH, "México-Argentina..." Op. Cit, p. 83.

198 G.A. a Eduardo Santos, Buenos Aires, Agosto 20, 1940, BNC, FGA, Caja 1, Carpeta 4.

${ }^{199}$ G.A. a Alfonso Holmberg, Buenos Aires, Septiembre 05, 1940. BNC, FGA, Caja 1, Carpeta 4. 


\section{A política argentina nas cartas de Arciniegas.}

Os informes de Arciniegas sobre a política argentina começaram a permear a correspondência apenas em julho de 1940. Sua impressão era de que antes dessa data a situação no país era calma e estável. "EN BUENOS AIRES EL MUNDO NO CA(M)BIA DE MODO APRECIABLE"200, escreveu a Urdaneta em agosto de 1940. Como também foi dito acima, suas notas permitem vê-lo como uma espécie de repórter oficial, que, de se mostrar alheio à dinâmica política local passa, em poucas semanas, a delinear o quadro de posições, se atrevendo até a anunciar possíveis transformações. Arciniegas acompanhou sempre estes informes com recortes da imprensa liberal e trechos ou cópias dos discursos mais enfáticos pronunciados no parlamento em meio à crise desatada pelos escândalos de corrupção, a renúncia do presidente Roberto Ortiz (1886-1942) e as subsequentes mudanças nas coalisões de poder.

Arciniegas começou a descrever a movimentação da política argentina em julho de 1940, quando apenas era afetada pela frágil saúde do presidente, concentrando a atenção nas possíveis consequências sobre a política exterior, pois "SI ESA ENFERMEDAD SE PROLONGA, Y EL VICEPRESIDENTE DOCTOR CASTILLO CONTINÚA FIRME, HABRÁ SEGURAMENTE UN CAMBIO DE ORIENTACIÓN EN LA POLÍTICA", e que "SE CONSIDERA MUY POSIBLE UNA CRISIS MINISTERIAL QUE TENDRÍA POR CONSECUENCIA INMEDIATA LA SUSTITUCIÓN DEL CANCILLER CANTILLO”20I

A opinião de Arciniegas sobre um estado de calma na política argentina, antes de julho de 1940, ignorou o estado quase permanente de turbulência experimentada no país no curso de toda a década de trinta, atravessada por governos autoritários erigidos sobre a fraude. Arciniegas ainda transmitia a aceitação das fraudes como aspecto natural da política austral. Mas a atitude do escritor mudou aos poucos. Em agosto estourou um escândalo de corrupção na compra de um terreno para o Exército, o caso de "El Palomar", que levou ao aprofundamento da crise no governo $^{202}$. Por outro lado, suas previsões sobre os efeitos da crise na política exterior resultaram parcialmente corretas. O vice-presidente Ramón Castillo (1873-1944) permaneceu no poder e houve, em janeiro, a substituição do chanceler José María Cantilo (1877-1953), mas a política de

${ }^{200}$ G.A. a Rafael Urdaneta, Buenos Aires, agosto 09 de 1940, BNC, FGA, Caja 1, Carpeta 4.

${ }^{201}$ G.A. a Eduardo Santos, Buenos Aires, Julio 23 de 1940, BNC, FGA, Caja 1 Carpeta 4.

${ }^{202}$ G.A. a Rafael Urdaneta, Bueno Airez, Agosto 13 de 1940, BNC, FGA, Caja 1, Carpeta 4. 
neutralidade se manteve. O que parece ter acontecido foi uma mudança nos círculos liberais perante essa política, agora associada a supostas afinidades do governo com o Eixo ${ }^{203}$.

As cartas de Arciniegas para Santos tiveram uma extensão máxima de três páginas em agosto de 1940. Não chegaram à exaustividade que outros intelectuais diplomáticos mostraram em seus informes $^{204}$, mas dão conta da agilidade jornalística para observar um panorama instável. A crise no governo foi sendo cada vez mais clara para o escritor, que encaminhava ao presidente, costumeiramente, recortes da imprensa liberal portenha:

ACA HAY UNA SITUACIÓN POLÍTICA CRÍTICA. CON MOTIVO DE LA COMPRA QUE HIZO EL GOBIERNO DE UNOS TERRENOS PARA EL EJERCITO, -LOS TERRENOS DEL PALOMAR-, SE HA HABIERTO (sic) UNA INVESTIGACIÓN Y HAN RESULTADO COMRPOMETIDOS PERSONAJES MUY PROMINENTES DE LA POLÍTICA, DESDE EL MINISTRO DE GUERRA PARA ABAJO. LE ENVÍO UN RECORTE QUE LE DARÁ IDEA DEL ALCANCE DEL ASUNTO (...) AYER EL EDIFICIO DEL CONGRESO ESTABA RODEADO DE POLICÍA Y LA SESIÓN DURÓ DE LAS CUATRO DE LA TARDE A LAS DOCE DE LA NOCHE. EL ANUNCIO DE ESTOS SUCESOS PARECE QUE HA SIDO LA CAUSA DE QUE SE HUBIERA APLAZADO UNA CRISIS MINISTERIAL, QUE ESTUVO PLANTEADA HACE UNAS TRES SEMANAS, PERO LO QUE DE TODO ESTO RESULTE PUEDE TRAER CAMBIOS MUY GRANDES EN LA POLÍTICA ARGENTINA" ${ }^{205}$.

O caso de "El Palomar" foi um ponto de interesse para Arciniegas quem acreditava que a vida política argentina era tranquila demais. O episódio permitiu ao escritor frequentar o Congresso, uma atividade recorrente já na sua mocidade. Assim escreveu malicioso a Urdaneta, num tom de muita familiaridade:

“SUPONGO QUE EN ESTA OCASIÓN ME HABRÁ TENIDO USTED UN POCO DE ENVIDIA Y HABRÁ LAMENTADO NO ESTAR EN BUENOS AIRES. EN REALIDAD, LA POLÍTICA SE HA MOVIDO COMO NUNCA, Y LAS SESIONES DEL CONGREO HAN REVESTIDO EL MAYOR INTERÉS. EL DIA EN QUE SESIONÓ LA ASAMBLEA HUBO EXTRAORDINARIA AGITACIÓN. YO ASISTÍ UNAS CINCO HORAS DE SESIÓN (DURÓ SEIS), Y OÍ LOS DISCURSOS DE TODOS LOS DIRECTORES DE GRUPOS POLÍTICOS Y DE MUCHOS ESPONTÁNEOS. TODO DENTRO DE UNA GRAN MESURA Y ORDEN. EN DISCURSOS ESCRITOS Y CORTOS, PERO POR LO MISMO DE GRAN INTERÉS POR LA MANERA COMO SE ENFOCARON LOS ASUNTOS RELACIONADOS CON LA COMPRA DE LOS TERRENOS DEL PALOMAR DESDE TODOS LOS PUNTOS DE VISTA IMAGINABLES. CREO QUE EN ESA SESIÓN SE SUPO MÁS DE POLÍTICA ARGENTNA QUE LEYENDO LOS PERIÓDICOS DE TODO UN ANO ${ }^{\prime 206}$.

Arciniegas admirou-se, na primeira impressão, com os debates parlamentares. Desde sua juventude bogotana, gostava de observar as sessões do Congresso e ele próprio havia sido

\footnotetext{
${ }^{203}$ SENKMAN...Op. Cit.

${ }^{204}$ MYERS...Op. Cit.

${ }^{205}$ G.A. a Eduardo Santos, Buenos Aires, Agosto 20 de 1940, BNC, FGA, Caja 1, Carpeta 4.

${ }^{206}$ G.A. a Rafael Urdaneta, Buenos Aires, Septiembre 03 de 1940, BNC, FGA, Caja 1, Carpeta 4.
} 
deputado. Dessa experiência, tirou algumas crônicas carregadas de desencanto e ironia. O espetáculo do parlamento argentino pareceu-lhe de grande civilidade, com seus discursos escritos, pronunciados em voz moderada em meio à calma dos curiosos, em contraste com o barulho, "el ruído", principal personagem de suas crônicas de 1933 sobre o Congresso colombiano $^{207}$.

Arciniegas deixou de escrever sobre o escândalo de "El Palomar" em virtude do regresso de Urdaneta à Argentina. Mas quando esse partiu definitivamente de Buenos Aires, em princípios de 1941, o escritor retomou seus informes para Santos. Desta vez, iria transmitir as mudanças da atitude do governo frente à guerra decorrentes da crise ministerial. Arciniegas ecoou as críticas da imprensa liberal ao novo gabinete, sob direção do vice-presidente Castillo, que mantinha a política de neutralidade ${ }^{208}$. Sua preocupação foi ainda mais intensa já em outubro de 1941, em relação às pesquisas sobre a propaganda pro-eixo organizada na Argentina, pois "el ejecutivo no ha respaldado a la cámara en lo que se ha llamado la investigación de actividades antiargentinas", ainda quando parecia que "la Embajada Alemana (...) hubiera montado aquí una máquina gigantesca para irradiar sobre toda América”. Para Arciniegas, o governo ia perdendo legitimidade e conduzindo a politica argentina para a instabilidade, se levando em conta "el ningún respaldo que tiene el gobierno en la opinión, y la crítica implacable que a estas medidas hacen diarios como La Prensa y La Nación, y la crítica constante que oye uno en todas partes, podrá darse cuenta de lo inestable de la política hoy en la Argentina”.

Arciniegas considerava perigosa a conjuntura política. Para ele, a defesa da democracia tinha deixado de ser um senso comum na opinião pública e nos governos de América, o que identificava como um relaxamento moral, resultado da guerra:

"Me dá la impresión de que aquí, como en Colombia, y en todas partes, la consecuencia inmediata de la guerra ha sido un relajamiento de la moral colectiva, una pérdida de rumbo, una vacilación en los principios democráticos que es peligrosísima porque ocurre en el momento preciso en que más esencial es su afirmación rotunda y tranquila. Dos años más de guerra, y luego una postguerra llena de agitaciones, y será para nosotros América un caos si no hay quien imponga la moral perdida"209

207 Memorias de un congresista. Bogotá. Cromos. 1933. Arciniegas comparava o congresso colombiano com o parlamento inglês.

${ }^{208}$ G.A. a Eduardo Santos, Buenos Aires, Mayo 31 de 1941, BNC, FGA, Caja 1, Carpeta 5.

${ }^{209}$ G.A. a Eduardo Santos, Buenos Aires, Octubre 14 de 1941, BNC, FGA, Caja 1, Carpeta 5. Malgrado essa atitude da imprensa liberal argentina, ecoada por Arciniegas, foi apenas em janeiro de 1942 que os setores liberais do país 


\section{Conclusões}

As mediações culturais agenciadas pelo colombiano Germán Arciniegas foram favorecidas pelo lugar que ocupou na sociedade argentina como funcionário diplomático. Vários aspectos mostram a importância da acumulação de posições, como escritor, jornalista e diplomata, e a combinação do seu exercício, o que fez dessa confluência de papéis uma circunstância privilegiada para o exercício da mediação ${ }^{210}$, pois garantia, além do apoio material, atributos de prestígio que aproximavam o escritor a públicos e cenáculos heterogêneos. O diplomata, por sua vez, abonou a missão com seu prestígio de escritor, que fez vingar em jornais que atenderam suas reclamações e sugestões em matérias sobre a Colômbia. A dupla condição lhe permitiu também distribuir e mobilizar com certo grau de autonomia, recursos e bens que circulavam por vias oficiais.

A correspondência do escritor permitiu observar que Arciniegas era consciente da mistura de papéis e do lugar que ocupava a missão colombiana em Buenos Aires. Também do sentido que quis impor às iniciativas que impulsionou: com sentido pedagógico no intuito de levar ao público e aos artistas colombianos mostras de gravuras que circulavam na Argentina; ou com um viés mais diplomático, oferecer aos argentinos uma imagem da cultura colombiana, fincada em suas raízes coloniais, e avançar na promoção de um liberalismo colombiano, associado à legalidade e a temperança nas transformações sociais. Arciniegas orientou sua atividade sobre a leitura que fizera do contraste entre as produções culturais colombianas e argentinas, no sentido de ressaltar a tradição colonial colombiana, e articular as atividades culturais do momento em seu país na década de 1940, ao dinamismo contemporâneo argentino. Essa forma de relação seria desenvolvida em outros aspectos da obra e em outros espaços e momentos da trajetória do escritor.

Arciniegas quis também oferecer pontes ideológicas para promover a defesa continental do liberalismo, a partir do entrosamento das tradições políticas de ambos os países, em especial de

exigiram o abandono da neutralidade. Até então, os jornais e associações antifascistas dedicaram-se apenas a combater as atividades dos grupos pronazistas e denunciar a atitude permissiva do governo. O abandono dessa orientação apenas veio se efetuar em 1945. SENKMAN...Op. Cit.

${ }^{210}$ Botrel...Op. Cit. 
seus traços de solidariedade continental. O exercício da mediação cultural assumiu uma orientação ideológica bastante clara. Arciniegas foi um representante oficial fiel à orientação do governo Santos, com quem estava estreitamente ligado por laços de amizade, o que resulta central para se entender as formas que adotaram suas funções, por exemplo, no tom e na disposição das cartas, dirigidas diretamente ao presidente e não a uma instância superior no Ministério de Relações Exteriores, misturando assuntos oficiais com questões pessoais. Mas, além disso, Arciniegas teve iniciativas como Encarregado de Negócios, em matéria comercial, que refletem o compromisso do escritor com os projetos de integração, ainda que também reflitam sua falta de perícia nestas funções.

A função ideológica que revestiu a mediação cultural baseada numa posição oficial foi reconhecida e confirmada pelos âmbitos portenhos que acolheram as iniciativas de Arciniegas e pelo tipo de empresas culturais às quais atrelou suas atividades, por meio das quais pode inserir propaganda a favor do regime colombiano e de sua política exterior, assim como a divulgação dos fragmentos selecionados da cultura colombiana.

Por fim, vale a pena mencionar que a carreira diplomática do escritor teria continuidade na segunda metade do século XX, quando a exerceu na Itália, Israel, Romênia, Vaticano e Venezuela $^{211}$. Mas seu vínculo com os governos liberais não teve um hiato tão extenso: com efeito, de regresso para Buenos Aires, de uma viagem aos Estados Unidos, Arciniegas se deteve em Bogotá para assumir o Ministério de Educação, um dos ministérios que mais ministros teve no período dos governos liberais. Arciniegas, que quando lhe foi oferecido o posto na Argentina não teve dúvidas em aceitar -"No digo que acepté, sino que le arranque la mano al doctor Santos"212 -; depois, nomeado ministro, sentiu a urgência de expressar aos seus amigos, e provavelmente a si, que não era a política a sua verdadeira vocação. Em carta a Federico de Onís escreveu: "le tengo verdadero terror a la vida política y no querría en ningún caso volver a ella jamás. Sólo la amistad particular que me liga al Señor Presidente me pudo comprometer para aceptar el Ministerio" ${ }^{213}$.

211 Campa, Annunziata. German Arciniegas: l'itinerario intellettuale di un latinoamericano in Italia, Annali d'Italianistica, num. 1, vol.14, 1996.

${ }^{212}$ Cacúa Prada...Op. Cit. p. 221.

${ }^{213}$ G.A. a Federico de Onís, Bogotá, 18/03/1942. BNC, FGA, Caja 1, Carpeta 6. 


\section{SEGUNDA PARTE}

\section{Arciniegas e a Argentina: editoras, imprensa e viagem, 1940-1960.}

\section{Introdução}

Germán Arciniegas construiu vínculos com a Argentina que foram além das funções diplomáticas que exerceu no período 1939-1941. Nas décadas seguintes o escritor continuou uma colaboração com as editoras sediadas na capital argentina. Sobre essa relação o escritor pretendeu estabelecer pontes entre os escritores colombianos e a indústria editorial das Américas, dinamizar o panorama cultural de seu país e procurar a integração intelectual do continente.

De outro lado, Arciniegas concebeu entre 1940 e 1960 certas representações da cultura argentina que transmitiu aos leitores colombianos. Desde sua posição como colaborador do jornal $E l$ Tiempo de Bogotá, o escritor pôde não só testar e arejar essas impressões, tiradas de leituras e impressões de viagens, mas também agenciar um cotejo entre as tradições da Colômbia e a Argentina, orientado para a promoção de um projeto cultural, com o qual reforçava suas tomadas de posição no espaço nacional. 


\section{Capítulo 3. Germán Arciniegas e as editoras argentinas, 1940-1960.}

\section{Introdução}

O mundo editorial é uma instância central das mediações culturais. As possibilidades maiores ou menores de circulação dos livros, as marcas que impõe sobre a obra o selo da casa editorial que a publica, assim como a coleção em que aparece, popular ou de luxo, tanto quanto as mudanças nas obras propostas tantas vezes pelos editores em função de sua dupla posição como agentes culturais e comerciais, são questões que salientam a importância do mundo editorial nas mediações culturais e na circulação internacional de ideias que elas supõem.

Neste capítulo, propomos uma leitura do cruzamento das atividades desenvolvidas pelo escritor Germán Arciniegas e as editoras argentinas com as quais se vinculou no começo da década de $1940^{214}$. A correspondência mantida entre esses agentes do circuito intelectual latino-americano, permite observar uma relação plural na qual assuntos os mais diversos superaram as questões relativas às edições dos próprios livros do escritor colombiano e de sua circulação. Com efeito, outras matérias permearam esta correspondência: o andamento da indústria do livro na Argentina e as dificuldades para consolidar um mercado editorial americano, a orientação das casas editoriais e sua expansão continental, além da política argentina na década de 50 . O estudo desta relação favorece também a compreensão das condições de consagração continental de Arciniegas como escritor e das caraterísticas do americanismo projetado por ele e pelas editoras que acolheram suas obras.

Losada e Sudamericana foram as principais editoras que receberam os livros originais de Arciniegas a partir de 1940 e que fizeram reedições de suas obras até a década de 1980. Os vínculos de Arciniegas com outros espaços editoriais em língua espanhola - mexicano e espanhol-, passaram muitas vezes pela mediação destas casas portenhas. Nesse intercâmbio plural, é clara a permanência do vínculo empresarial e pessoal em meio às vicissitudes de um mundo em transformações sucessivas e conflitantes, como foi o cenário latino-americano das décadas de trinta a sessenta. Nesse período, é notável a confluência de esforços no sentido de

\footnotetext{
${ }^{214}$ Sobre a riqueza da correspondencia entre autores e editores no contexto latino-americano ver: Pereira Theodozio, Vera María. Autor \& edição: três sub-séries da Correspondência João Guimarães Rosa (1957-1967). Tese apresentada para obter o título de Doutor em História. São Paulo. USP. 2011.
} 
propalar um projeto político e cultural americanista de signo liberal. Com efeito, esta relação pode-se considerar como um desdobramento da convivência do escritor junto à comunidade de espanhóis exilados na Argentina, pois foi justamente a afinidade política na defesa dos valores republicanos o que os aproximou. Além disso, o compromisso político de Arciniegas, dos espanhóis e de outros estrangeiros chegados à Argentina nessas décadas foi suficiente para serem acolhidos pelos âmbitos letrados localizados no "espectro liberal" do campo intelectual argentino $^{215}$. A relação entre o escritor o os editores atenta diretamente para o caráter coletivo, "em rede" das mediações culturais ${ }^{216}$.

Nas páginas a seguir mostraremos as condições das publicações dos livros de Arciniegas antes de sua chegada como funcionário diplomático à Argentina, para depois analisar a maneira como o escritor se vinculou às duas editoras mencionadas, assinalando as mediações exercidas por Arciniegas no sentido de guiar aos editores no mundo literário colombiano. Finalmente, discutiremos as estratégias e dificuldades das editoras para atingir os mercados da América Latina, mostrando o papel de Arciniegas no processo.

A edição dos primeiros livros de Arciniegas e sua penetração continental

A forma como foram publicados os primeiros livros do escritor colombiano reflete o estado da indústria no espaço hispano-americano durante a década de 1930, e os vínculos do escritor com diferentes redes de colaboração intelectual transnacional. O livro de estreia, El estudiante de la mesa redonda (Juan Pueyo, 1932) apareceu em Madri quando as edições espanholas estendiam sua influência sobre os mercados latino-americanos, superando a influência das editoras locais ${ }^{217}$. O interesse da casa espanhola decorreu da intervenção do mexicano José Vasconcelos, com quem Arciniegas manteve uma intensa colaboração ao redor do ativismo a favor da Reforma

\footnotetext{
${ }^{215}$ Neiburg, Federico, Los intelectuales y la invención del peronismo. Madrid/Buenos Aires, Alianza Editorial, 1988.

216 Joyeux, Beatriz. "Les tranferts culturels. Un discours de la méthode. Hyphothèses. 2002/1.

${ }^{217}$ Espósito, Fabio, "Los editores españoles en la Argentina: redes comerciales, políticas y culturales entre España y la Argentina (1892-1938). En: Altamirano, Carlos (director), Historia de los intelectuales en América Latina. v II. Buenos Aires, Katz, 2010, pp. 515-537.
} 
Universitária, relação às vezes mediada pelo poeta Carlos Pellicer, quem morou em Bogotá na década de $1920^{218}$.

Depois, junto à reedição bogotana dessa obra (Minerva, 1933), seus seguintes três livros foram publicados na capital colombiana, dois deles pela imprensa oficial ${ }^{219}$ : La Universidad en Colombia (Imprenta Nacional, 1932), Memorias de un congresista (Editorial Cromos, 1933) e Diario de un peatón (Imprenta Nacional, 1934). Esses textos tinham relação estreita com as atividades parlamentares e jornalísticas de Arciniegas, mas, daí em diante, o escritor concentrouse nos relatos históricos e na ensaística de interpretação cultural. Dos relatos históricos, publicou em Bogotá Los Comuneros (A.B.C., 1938) e Jiménez de Quesada (A.B.C., 1939). É importante mencionar que este último e o Diario de un peatón foram publicados pela Revista de las Indias, órgão oficial que o próprio Arciniegas dirigia ${ }^{220}$. Arciniegas só editou outro livro em Bogotá depois da década de 40, En el país de los rascacielos y las zanahorias (Librería Suramérica, 1945), no qual Arciniegas regressou à escrita de crônicas, agora como viajante nos Estados Unidos $^{221}$.

Seu primeiro volume de ensaios de interpretação cultural apareceu em Santiago do Chile (Ercilla, 1937). A indústria chilena do livro experimentou nos anos anteriores um crescimento importante favorecido pela interrupção dos pagamentos de direitos às editoras espanholas, então em crise pelo conflito civil e pela presença animadora da comunidade peruana vinculada ao APRA (Alianza Para la Rrevolución Americana) e exilada no país ${ }^{222}$. O peruano Luis Alberto Sánchez

${ }^{218}$ Zaitzeff, Sergei. "El joven Arciniegas a través de su correspondencia con Carlos Pellicer. Historia Crítica, No. 21, 2001, p. 71-75.

${ }^{219}$ O Partido Liberal, ao qual pertenceu Arciniegas, chegou ao poder em 1930 depois de 45 anos. Nos quinze anos de "República Liberal", até 1945, Arciniegas foi funcionário diplomático, representante na Câmara e Ministro da Educação.

${ }^{220} \mathrm{O}$ dado é sugestivo porque outros autores se queixavam naquele momento das dificuldades para serem publicados, das condições ruins nos contratos com os editores, e o que é mais importante, da falta de estímulo oficial. Vanderhuck Arias, Felipe, La literatura como oficio: José Antonio Lizarazo 1930-1946. Medellín. La Carreta Editores. Universidad Icesi. 2012. O caso de Arciniegas era claramente o contrário: um escritor favorecido pelo estímulo oficial não só para ser publicado, mas detendo posições de domínio sobre a cultura desde o próprio Estado: diretor de uma revista oficial, diplomata, Ministro da Educação.

${ }^{221}$ Anos antes, Arciniegas havia projetado a publicação de um livro similar com materiais de sua viagem à Inglaterra, La isla de los caballos, que não foi publicado. Algumas dessas crónicas foram recolhidas na primeira parte do Diario de um peatón, composto também por crônicas.

${ }^{222}$ Subercaseaux, Bernardo, "Editoriales y círculos intelectuales en Chile (1930-1950)". En: Altamirano, Carlos, Historia de los intelectuales...Op. Cit, pp. 567-580. 
(1900-1994), junto ao representante da Colômbia em Lima, Roberto García Peña (1910-1993) ${ }^{223}$, foi quem introduziu o manuscrito de Arciniegas no catálogo da editora. Foi a primeira obra do colombiano publicada num país latino-americano diferente à sua Colômbia natal. Ercilla publicou também em 1937 uma reedição de El estudiante de la mesa redonda e em 1939 a editora ZigZag, também de Santiago do Chile, contratou a reedição de Los Comuneros, que apareceu no ano seguinte. Vale a pena mencionar que as editoras chilenas estavam presentes no mercado colombiano, pelo menos nas feiras do livro acontecidas em Bogotá nesses anos ${ }^{224}$.

Pode-se afirmar que antes de seu desembarque em Buenos Aires, em dezembro de 1939, Arciniegas já havia começado a publicar em selos latino-americanos que então cresciam vigorosamente. Mas a partir de seu desembarque na capital argentina, o escritor decidiu investir forte em sua vinculação com as casas portenhas, capitaneadas por experientes editores espanhóis como Gonzalo Losada (1894-1981), Guillermo de Torre (1900-1971), Antonio López Llausás (1888-1965) e Julián Urgoiti. Dessa forma, Arciniegas atrelou sua carreira a este centro editorial e à articulação continental possível desde o eixo de relações bonaerenses ${ }^{225}$.

A notável expansão da indústria editorial argentina a partir de 1938 foi protagonizada por três empresas dirigidas por espanhóis que haviam acumulado experiências junto às editoras de ultramar. Sudamericana, Emecé e Losada, fundadas no final da década de 1930, fizeram do circuito bonaerense uma instância central para a consagração intelectual no mundo hispanoamericano $^{226}$. A intenção de atingir desde a Argentina os mercados americanos tinha animado livreiros e editores espanhóis desde o século XIX e pode-se afirmar que, até o começo da Guerra

${ }^{223}$ García Peña atuava como embaixador em Lima e era um dos escritores vinculados ao diário El Tiempo do qual seria diretor pouco depois do próprio Arciniegas. Juntos dirigiram, a partir de 1945, a Revista de América. O episódio demonstra mais uma vez a importância dos canais diplomáticos para os intercâmbios intelectuais do período.

${ }^{224}$ Silva, Renán. “Las ferias del libro en Colombia, 1936-1947” En: República liberal, inteletuales y cultura popular. Medellín. La Carreta Editores. 2005, pp. 187-222.

225 Como dito por Jorge Myers, a articulação do projeto de interpretação cultural da América gestou-se no cruzamento de várias redes de colaboração intelectual, uma das quais teve como núcleo aos "ateneístas" mexicanos do começo de século. Outros núcleos importantes estiveram articulados aos círculos bonaerenses. Alfonso Reyes e Pedro Henríquez Ureña foram elos entre estes e outros espaços. Gustavo Sorá chamou a atenção para Arnaldo Orfila Reynal, como outro agente deste "tecido intelectual" regional. MYERS, Jorge, Gênese "ateneísta" da história cultural latino-americana. Em: Tempo social. Revista de sociologia da USP, 17. São Paulo. 2005; Sorá, Gustavo, "Misión de la edición para una cultura en crisis. El Fondo de Cultura Económica y el americanismo en Tierra Firme”. En: Altamirano, Historia de...Op. Cit. Pp. 537-567.

${ }^{226}$ De Diego, José Luis (dir.) Editoriales y políticas editoriales en Argentina, 1880-2000, Buenos Aires, Fondo de Cultura Económica. 2006. 
Civil, em 1936, haviam avançado firmemente nesse propósito, apesar do crescimento das indústrias locais em alguns países como a própria Argentina. Os editores trasladados para a Argentina reproduziram essa vocação hispano-americanista, o que fez com que, já no contexto do peronismo, fossem acusados de serem empresários estrangeiros que deixavam de lado a cultura nacional $^{227}$.

Como aconteceu no caso chileno, a guerra espanhola foi um fator positivo para o desenvolvimento da edição na Argentina, pois deixou um espaço quando se deteve o fluxo de livros da península para América e a censura proibiu a edição de alguns títulos interessantes para certos públicos americanos. Mss também porque esse mesmo espaço foi depois coberto por empresas locais que acolheram alguns dos editores espanhóis, agora exilados. Como se sabe, uma experiência similar aconteceu no México, onde esta indústria cresceu em níveis comparáveis aos da Argentina, mas o fez em campos da edição que, de certa forma, antes que competir se complementavam com a produção austral. Isso fez com que durante a década de 1940 existisse não só uma colaboração logística, mas uma articulação de projetos culturais entre algumas das editoras mais representativas desse movimento ${ }^{228}$, ainda que mais tarde a relação entre as indústrias desses países se mostrassem conflitantes, dando com resultados negativos para a circulação da produção literária e a integração intelectual da região -e da obra de Arciniegas, para o caso, especificamente - como se verá mais à frente ${ }^{229}$.

Edições, coleções editoriais e colaboração intelectual.

Losada.

Os primeiros contatos que estabeleceu Arciniegas com essas empresas não foram relativos exclusivamente à edição ou reedição de seus livros. Uma das prioridades do escritor durante esses

227 Giuliani, Alejandra, Libros o alpargatas. "El comienzo de una historia. Editores, escritores y política en la Argentina de 1945”. Prólogos, v. II. 2009, pp. 59-78.

${ }^{228}$ Sorá, Gustavo. "Editores y editoriales de ciencias sociales: un capital específico". En: Neiburg, Federico y Plotkin, Mariano, Intelectuales y expertos...Op. Cit. pp. 265-292.

${ }^{229}$ A Colômbia recebeu um fluxo menor de exiliados espanhóis. Ainda assim, o país também teve um editor de origem peninsular que animou o mundo do livro no país, embora as condições locais não tenham permitido o desenvolvimento de projetos como os descritos para México ou Argentina. Foi Clemente Airó com a editora Espiral. Cobo Borda. Juan Gustavo, "Historia de la industria editorial colombiana" En: Cobo Borda, Juan Gustavo (editor), Historia de las empresas editoriales de América Latina. Siglo XX. Bogotá, CERLALC, 2000, pp. 161-188. 
anos foi a Revista de las Indias, que ele dirigiu entre 1938 e 1944, e para a qual procurou colaborações entre os escritores do circuito portenho, entre eles alguns membros da editora. É importante mencionar que até esse momento, a revista não tinha colaboradores da Argentina, o que era indicado insistentemente, por exemplo, por Baldomero Sanín Cano e Luis Alberto Sánchez ${ }^{230}$. Arciniegas quis também que a editora publicasse anúncios nas páginas da revista e que assumisse sua distribuição na Argentina. Gonzalo Losada rejeitou o negócio da distribuição, mas aceitou publicar em suas páginas a listagem das novidades do catálogo: "simplemente a cambio del servicio de nuestras publicaciones tal como lo venimos haciendo en Repertorio Americano de Costa Rica, "Revista Hispánica de New York”, etc"231. Já Guillermo de Torre, escritor espanhol que atuava como diretor de coleções na editora chegou a ser um dos maiores colaboradores de Arciniegas, não só enviando artigos para essa revista, mas também para a Revista de América e Cuadernos, dirigidas por Arciniegas nas décadas seguintes desde Bogotá e Paris, respectivamente. $\mathrm{O}$ entendimento entre eles foi rápido e sincero. Tempos depois De Torre já pedia o conselho de Arciniegas sobre a pertinência de publicar os anúncios da editora em outros meios colombianos, como o jornal conservador El Colombiano ${ }^{232}$.

A Revista de las Indias era a empresa intelectual mais importante de Arciniegas e seu vínculo mais efetivo com o ambiente cultural colombiano depois de deixar o país e a direção do jornal $E l$ Tiempo em fevereiro de 1938. A qualidade que tinha atingido em pouco mais de um ano lhe permitiu apresentar-se como um intelectual ativo, de bom critério e com algo a oferecer aos seus colegas na Argentina.

Losada foi fundada em 1938 por Gonzalo Losada, Guillermo de Torre y Atilio Rossi. Somaramse depois Francisco Romero, Amado Alonso e Pedro Henríquez Ureña. Seu principal sócio havia sido representante da editora espanhola Espasa-Calpe em Buenos Aires desde 1928, tendo construído um conjunto de relações nos círculos letrados locais e adquirido conhecimento sobre as exigências e possibilidades do mercado portenho. Por isso não se pode considerar Losada como um exilado, ainda que sua orientação republicana transparecesse sempre nas escolhas

\footnotetext{
${ }^{230}$ Arbeláez, Carlos. Germán Arciniegas: Un proyecto americanista por correspondencia. Bogotá, 2014. Inédito.

${ }^{231}$ Guillermo de Torre a G.A. 27/02/1940, BNC, FGA, Caja 27, Carpeta 5; G.A. a Editorial Losada, 02 /07/1940, BNC, FGA, Caja 1, Carpeta 4.

${ }^{232}$ Guillermo de Torre a G.A., 16/09/ 1940, BNC, FGA, Caja 27, Carpeta 5.
} 
editoriais do novo selo. Junto aos autores espanhóis republicanos, a editora procurou desde o começo consolidar um catálogo de livros inéditos de autores americanos.

Desde os primeiros contatos com a editora, Arciniegas procurou simultaneamente a reedição de alguma de suas obras aparecidas na Colômbia ${ }^{233}$ e a publicação de outros autores colombianos. Isso mostra bem como se conjugavam o papel de mediador cultural, somado nesses primeiros anos às funções diplomáticas, com a promoção da própria obra. Gonzalo Losada aceitou editar dois autores colombianos que não representavam grande risco comercial graças à sua familiaridade nos meios locais: José Asunción Silva y Baldomero Sanín Cano. Além disso, Arciniegas propôs a publicação de três antologias: uma do poeta Guillermo Valencia, outra de contos colombianos e uma última "del castellano en Colombia”, sobre todas as quais Gonzalo Losada mostrou pouco entusiasmo. A mesma reticência inicial foi transmitida ao escritor a propósito da reedição de alguma de suas obras. O interesse da editora eram os originais.

Alguns meses depois, Losada ofereceu a Arciniegas a redação de um volume da "Biblioteca del Pensamiento Vivo", coleção voltada a brindar textos clássicos e antologias dos mais diversos autores, com um espaço reservado aos espanhóis e latino-americanos. O editor propôs que Arciniegas selecionasse e prologasse os textos de Andrés Bello ${ }^{234}$. Além de autor, Arciniegas pode ser novamente conselheiro da editora quando De Torre recebeu a proposta de incluir dois autores colombianos -Rafael Núñez e Miguel Antonio Caro- nesta Biblioteca: "antes de responder a este señor (Lucio Pabón Núñez, que fez a proposta ${ }^{235}$ ), querríamos saber qué le parece a usted: si estima que esas figuras son las más representativas del "pensamiento vivo" de Colombia" 236 , lhe escreveu De Torre.

\footnotetext{
${ }^{233}$ Entre as vantagens derivadas do vínculo com as editoras chilenas e argentinas, estiveram, além da qualidade da edição, a tiragem maior e as condições de distribuição não só para o nível continental, pois consta na correspondência que Arciniegas se encarregava diretamente de vender às livrarias colombianas seus livros editados em Bogotá na década de trinta.

${ }^{234}$ G.A. a Editorial Losada, 02/07/ 1940. BNC, FGA, Caja 1, Carpeta 4. Arciniegas entregó el original en abril de 1941: G.A. a Editorial Losada, 23/04/1941. BNC, FGA, Caja 1, Carpeta 5

235 Pabón Nuñez foi importante político e escritor conservador colombiano. Em 1941 era estudante de direito, mas dois anos depois já se destacava como senador. Ocupou o Ministério de Governo no período do general Gustavo Rojas, foi também Ministro de Educação e embaixador em Portugal e na Argentina na década de 1950. Autor de "Relaciones culturales entre Colombia y la Argentina". En Boletín de la Academia Colombiana, Bogotá, XXV, 1975, págs. 244-251.

${ }^{236}$ Guillermo de Torre a G.A. 06/09/ 1941. BNC, FGA, Caja 27, Carpeta 5. Consulta aparte, De Torre ya anunciaba que por el momento era imposible incluir esas dos figuras en la colección.
} 
O significativo é que Arciniegas fosse consultado pelos diretores da editora em duas ocasiões em que se pretendeu vinculá-la com meios e personagens enraizados na tradição conservadora da Colômbia. O zelo de Gonzalo Losada e seus companheiros para não admitir ambiguidades a respeito da orientação ideológica de sua empresa foi central na construção de uma relação íntima com Arciniegas, ratificada na hora de o escritor virar sócio da editora - Arciniegas investiu em ações suas regalias ${ }^{237}$ - e depois no momento da instalação de uma sucursal de Losada em Bogotá, como se verá mais adiante. A construção de redes de colaboradores que agenciam as mediações, assim como a execução das seleções dos materiais a serem incorporados no fluxo da rede, tem como base a afinidade política e certo grau de homologia entre os projetos intelectuais do escritor e o editor ${ }^{238}$.

A partir da entrega do texto de Andrés Bello, em abril de 1941 - o livro só saiu em 1946-, Arciniegas empreendeu um intercâmbio mais intenso com a editora. Em 1941, deixou os originais de Los alemanes en la conquista de América. Depois Losada aceitou reeditar Jiménez de Quesada sob o novo título da versão em inglês ${ }^{239}$ : El caballero de El Dorado, que apareceu em 1942 na coleção "Biblioteca Contemporánea", de vocação popular e uma das principais linhas editoriais de Losada, dirigida por Guillermo de Torre. Nesse mesmo ano, Arciniegas pediu a Ercilla o fechamento do contrato de América, tierra firme e o ofereceu a Losada em termos que assinalam as coordenadas de suas afinidades sobre o americanismo: "Yo a ratos pienso que este libro puede tener mayor aceptación que el “Jiménez de Quesada” por tratarse de un tema de carácter más general y porque el libro en sí ha sido, al menos aquí, comentado con más efusión que el otro" ${ }^{240}$.

Nos anos seguintes as edições de livros originais de Arciniegas em Losada foram escassas. Embora Gonzalo Losada tenha pedido direta e insistentemente novidades ao escritor - por

\footnotetext{
${ }^{237}$ Arciniegas comprou duas ações em março de 1941, outra em dezembro do mesmo ano, mais cinco em dezembro de 1942, mais duas em dezembro de 1944 e outras duas um ano mais tarde: Gonzalo Losada a G.A., 15/03/de 1948, BNC, FGA, Caja 20, Carpeta 5.

238 Bourdieu, Pierre. "Las condiciones sociales de la circulación internacional de las ideas". En: Intelectuales, política y poder. Buenos Aires, Eudeba, 2000

${ }^{239}$ The knight of El Dorado. The Tale of Don Gonzalo Jimenez de Quesada and His Conquest of New Granada, Now Called Colombia. New York. Viking Press, 1942. Esta tradução e edição tinha sido favorecida pelas gestões pessoais do escritor austríaco Stefan Sweig. Arciniegas conheceu Sweig em Buenos Aires, quando já exilado no Brasil foi convidado à casa da escritora Victoria Ocampo.

${ }^{240}$ G.A. a Gonzalo Losada, 24/08/1942. BNC, FGA, Caja 1, Carpeta 6.
} 
exemplo, um livro sobre o Caribe e outro sobre Simonetta Vespuci ${ }^{241}$-, desde 1945 o escritor destinou seus livros à Sudamericana. Não obstante, a colaboração com Losada e seus diretores se manteve e a correspondência com eles não diminuiu em virtude das reedições mais ou menos constantes de seus livros, que foram sucessos comerciais, e dos pagamentos periódicos por vendas e dividendos das ações na editora. Entretanto, dois novos projetos, frustrados ambos, atravessaram os intercâmbios epistolares até a década de 1950: a edição em espanhol de The green continent ${ }^{242}$-volume preparado para os estudantes norte-americanos ${ }^{243}$ no qual Arciniegas apresentava descrições da paisagem e da cultura americana por meio de uma coletânea de fragmentos literários de vários autores - e a preparação de uma "História de América" coletiva, a cargo de José Luis Romero (1909-1977), diretor da “Biblioteca Histórica” da editora.

Sobre a primeira dessas obras se conservam algumas missivas pedindo e enviando os fragmentos transcritos, assim como uma listagem deles e uma carta na qual se pede a intermediação de López Llausás, diretor da Sudamericana, para obter a autorização de Victoria Ocampo para publicar um trecho de um artigo seu ${ }^{244}$. Em relação ao projeto de Romero pode-se dizer algo mais, pois os intercâmbios que motivou oferecem uma janela às representações que os editores tinham do escritor, sobre suas condições de produção intelectual e sobre as possibilidades de articulação entre seus projetos editoriais e o projeto criativo de Arciniegas.

A "Historia de América", explicou Romero, "tiene en total 4 volúmenes de 600 páginas cada uno y está dedicada a un público general" 245 . Junto à intenção de abranger um público amplo, buscava oferecer una visão complexa que abordasse aspectos os mais variados da experiência histórica: "Se trata de un relato con indicación preferente de hecho, destinado a fijar los puntos fundamentales del desarrollo económico, social, político y espiritual del país, pero sin aparato erudito ni cuestiones críticas" ${ }^{246}$. A coletânea não pretendia ser o lançamento de uma história continental construída sob os padrões científicos associados à profissionalização da disciplina.

\footnotetext{
${ }^{241}$ Gonzalo Losada a G.A, 30/07/1952, BNC, FGA, Caja 20, Carpeta 5.

242 Arciniegas, Germán, The Green Continent: A Comprehensive View of Latin America by Its Leading Writers. New York. Knopf, 1944.

${ }^{243}$ A partir de 1943 Arciniegas visitou regularmente diversas universidades dos Estados Unidos ministrando cursos de verão sobre a política a história e a literatura latino-americanas. Desde 1948 vinculou-se ao departamento de espanhol da Columbia University, onde permaneceu por dez anos.

${ }^{244}$ Guillermo de Torre a G.A., 17/10/1945. BNC, FGA, Caja 27, Carpeta 5.

245 José Luis Romero a G.A., 02/11/1949, BNC, FGA, Caja 20, Carpeta 5.

246 Ibíd.
} 
Pelo contrário, se acercava ao tipo de ensaio que cultuou Arciniegas: o relato carente de aparato de erudição e de discussões metodológicas ou teóricas ${ }^{247}$.

Romero quis que Arciniegas redigisse três artigos que abrangessem os séculos XIX e XX, deixando o período colonial da Nova Granada ao historiador espanhol José María Ots Capdequí. Tempos depois, De Torre pediu para que Arciniegas redigisse mais um artigo, desta vez sobre os "movimientos emancipatorios en toda América (solamente el aspecto político)"248. Apesar da insistência de Romero, De Torre e Losada, Arciniegas desistiu de sua participação na obra. Romero então quis seu conselho na escolha de um substituto:

\begin{abstract}
"No se imagina Ud. cuanto siento su negativa para colaborar en nuestra Historia. Desde cierto punto de vista, Ud. es Arciniegas o Colombia para el Río de la Plata. Esto significa que no sé como reemplazarlo. Tengo los siguientes nombres a la vista: Juan Lozano y Lozano, Luis López de Mesa, Jorge Zalamea y Alberto Lleras. Podría usted aconsejarme acerca de quién podría hacer estos capítulos con más calidad y menos retórica? Creo que Ud. me entiende. Acaso conozca Ud. alguna gente joven capaz de hacerlo"249
\end{abstract}

Dentre estes quatro nomes, vinculados ao liberalismo colombiano - todos eles tinham sido ministros e Lleras presidente-, Arciniegas sugeriu López de Mesa ${ }^{250}$ que também rejeitou a proposta, indicando por sua vez a Enrique Otero D’Acosta (1883-1964), mais um escritor e político liberal. Romero, logicamente, também consultou Ots Capdequí que recomendou Alberto Miramón, liberal também e velho companheiro de Arciniegas na redação da Revista de las Indias $^{251}$. Romero escreveu de novo para Arciniegas, sem ocultar o constrangimento: "Una vez más le pido disculpas. Si Ud. tuviera otro candidato que prefiriera a estos, no deje de decírmelo, pues su consejo es para mí del mayor valor. " 252.

\footnotetext{
${ }^{247}$ A empreitada não carecia de antecedentes no espaço argentino. Ricardo Levene, figura hegemônica do campo historiográfico portenho da primeira metade do século XX, organizou no começo da década de 1940 uma "Historia de América" na editora Jackson. Pode-se sugerir que a obra de Romero pretendia oferecer uma alternativa à de Levene. Arciniegas manteve com Levene uma colaboração que não chegou a estabelecer com Romero, aliás, mais jovem. Sobre as práticas historiográficas de Levene e Romero, entre outras, ver Myers, Jorge, "Pasados en pugna: la difícil renovación del campo histórico argentino entre 1930 y 1955”. En: Neiburg, Federico, Plotkin, Mariano. Intelectuales y expertos. La constitución del conocimiento social en la Argentina. Buenos Aires, Paidós, 2004, pp. 67-106. A editora Jackson, dirigida em Buenos Aires pelo espanhol exilado Ricardo Baeza, publicou a enciclopédia "Clásicos Jackson" na qual Arciniegas foi encarregado dos volumes de Quevedo e dos "Cronistas de Indias".

${ }^{248}$ Guillermo de Torre a G.A. 21/03/1951. BNC, FGA, Caja 27, Carpeta 5. Sublinhado no original.

${ }^{249}$ José Luis Romero a G.A., 18/12/1949, BNC, FGA, Caja 20, Carpeta 5

${ }^{250}$ Sua escolha, mais do que refletir afinidades com López, teve a ver com a disposição e as ocupações dos outros candidatos, que exerciam importantes posições públicas.

${ }^{251}$ Miramón e Arciniegas ministraram juntos a cátedra de sociologia na Faculdade de Direito da Universidade Nacional em Bogotá.

${ }^{252}$ José Luis Romero a G.A., 20/03/1950, BNC, FGA, Caja 20, Carpeta 5.
} 
As atividades de Romero na construção da "Historia de América" se estenderam por vários anos. Em 1956, De Torre voltava a insistir, o que revela as dificuldades que tinha para substituir Arciniegas. A carta De Torre pode ilustrar a "política da amizade" 253 que entrava em jogo nas colaborações intelectuais, além de brindar uma bem humorada leitura sobre as condições de produção intelectual de Arciniegas na década de 50, quando de sua vinculação como professor de literatura hispano-americana na Columbia University:

\begin{abstract}
"le recuerdo que usted no ha contestado todavia a una carta mía de hace meses donde le rogaba su contribución a nuestra Historia de América dirigida por José Luis Romero. No me diga, querido amigo, usted que escribe sobre omni re scibili ${ }^{254}$ y que saca tiempo de un sombrero de copa, que no puede hacerse cargo de ese trabajo. Se halla usted, además, en gloriosas condiciones de superioridad sobre cualquiera de los desvalidos que aquí o en otros lugares de América Hispana nos encontramos, ya que puede tener a la mano tocando un botón, toda la bibliografía que necesite en un minuto. De modo que espero su respuesta pronta y afirmativa. José Luis Romero, la Editorial Losada y yo mismo nos sentiríamos muy honrados con que su nombre quedara incorporado a esta Historia" 255 .
\end{abstract}

Seu pedido não foi bem sucedido. No entanto, o contraste entre essa missiva e a última de Romero - mais jovem que De Torre e os outros fundadores de Losada, entre eles seu próprio irmão Francisco- reflete a proximidade da relação construída por Arciniegas e os diretores da editora. Com efeito, Losada foi um espaço de sociabilidade que favoreceu a formação de vínculos intelectuais, políticos, comerciais e afetivos ${ }^{256}$. Para Arciniegas, a editora foi um canal para manter-se conectado com a intelectualidade portenha. Em todas suas cartas, Gonzalo Losada e Guillermo de Torre nunca deixaram de comunicar as mensagens dos outros membros da "casa", especialmente de Pedro Henríquez Ureña, sempre lembrando dos muitos “buenos amigos” que o escritor tinha deixado em Buenos Aires.

Sudamericana

Como no caso da Losada, a colaboração entre Arciniegas e os membros da editora, particularmente com seu dono e diretor Antonio López Llausás, superou a simples edição de suas obras. Desde 1945, López havia agido para autorizar a publicação do texto de Victoria Ocampo, incluído na versão em espanhol de The green continent. López era um assíduo visitante da casa

\footnotetext{
${ }^{253}$ Fontes Piazza, Maria Fátima. "Politicas de amizade: Portinari e o mundo cultural ibero-americano". Topói. V. 7. No. 12. Janeiro-Julho 2006, pp. 222-246.

${ }^{254}$ De todo lo que se puede saber.

${ }^{255}$ Guillermo de Torre a G.A., 05/04/1956. BNC, FGA, Caja 27, Carpeta 5.

256 Dabusti De Muñoz, María Teresa: “Trayectoria de Lorenzo Luzuriaga en Losada, una editorial en el exilio". En: Revista de Historia Contemporánea, N9-10, Sevilla, 1999-2000; y Neiburg, Federico, Los intelectuales y la invención...Op. Cit.
} 
de Ocampo em Mar del Plata, e por meio dele Arciniegas sempre recebeu notícias dela e do escritor espanhol Ramón Gómez de la Serna ${ }^{257}$. Além disso, López Llausás ofereceu a Arciniegas uma colaboração notável, passando-lhe capítulos de livros inéditos para serem publicados nas revistas dirigidas pelo colombiano ${ }^{258}$. O serviço era rentável para Sudamericana, que ganhava propaganda e difusão para suas novidades. Todavia, a obtenção de outras colaborações não era fácil, pois como escreveu López: "Me dicen que sí, que le enviarán algún artículo, pero como $U d$. sabe, salvo honrosas excepciones, entre las que se cuenta Ud., los escritores son bastante perezosos y les cuesta tomar la pluma" ${ }^{, 259}$.

Sudamericana foi fundanda em 1938 por um grupo heterogêneo de acionistas, composto, entre outros, pelos escritores argentinos Oliverio Girondo e Victoria Ocampo. López Llausás chegou mais tarde da França, onde estava exilado, e aos poucos foi adquirindo a totalidade da editora. Em 1945 dirigia a empresa junto a Julián Urgoiti, que antes havia trabalhado junto a Gonzalo Losada na sucursal de Espasa-Calpe.

O vínculo de Arciniegas com Sudamericana foi posterior ao estabelecido com Losada, embora mais extenso. Apesar da amizade com López Llausás vir da época da missão diplomática, apenas em 1945 apareceu na editora Biografía del Caribe. Arciniegas então já era um escritor bem conhecido nos meios argentinos. Premonitoriamente, López escreveu a Arciniegas: "puedo asegurarle que la conjunción de su nombre y de nuestro pie editorial asegura un gran éxito al libro", assinalando precisamente o efeito de "marcação" de uma obra pelo selo que a publica, e a transferência recíproca de "capital simbólico" entre autor e casa editorial. Esse efeito de marcação é fundamental na circulação transnacional de ideias ${ }^{260}$. O editor optou pela "Historia del Caribe" e não por alguma reedição; e sua escolha não pôde ser melhor: Biografia del Caribe

\footnotetext{
257 Antonio López Llausás a G.A., 31/03/1946, BNC, FGA, Caja 20, Carpeta 8; Antonio López Llausás a G.A., 03/09/de 1947, BNC, FGA, Caja 20, Carpeta 8; Antonio López Llausás a G.A., 30/08/1948, BNC, Fondo FGA, Caja 20, Carpeta 8.

258 Antonio López Llausás a G.A., 09/01/1945, BNC, FGA, Caja 20, Carpeta 8; Antonio López Llausás a G.A. 30/04/1946, BNC, FGA, Caja 20, Carpeta 8; Antonio López Llausás a G.A., 22/05/1946, BNC, FGA, Caja 20, Carpeta Editorial Sudamericana; Antonio López Llausás a G.A., 03/09/1947, BNC, FGA, Caja 20, Carpeta 8.

${ }^{259}$ Antonio López Llausás a G.A., 29/05/1945, BNC, FGA, Caja 20, Carpeta 8.

${ }^{260}$ Bourdieu, Pierre. "Las condiciones...” Op. Cit.
} 
teve um sucesso comercial enorme, ganhando a segunda edição já em 1947, a terceira em 1951, a quarta em 1954, até fazer do livro um best-seller, como disse o mesmo López em $1955^{261}$.

Em 1947, Arciniegas ofereceu ao editor mais dois livros: um intitulado provisoriamente "Descubrimiento de Europa" e um romance com o nome, também provisório, de "Un mundo a bordo"262. O editor inclinou-se pelo romance, por uma razão editorial: "preferiría la novela porque es un género que en nuestra colección HORIZONTE donde hemos tenido la suerte de publicar espléndidas novelas de buenos autores, estoy seguro que se vendería mucho", enquanto para o outro texto não havia uma coleção adequada ${ }^{263}$. Por isso, En medio del camino de la vida, único romance de Arciniegas, saiu em 1949. Esse livro, de venda mais lenta, apenas teria uma segunda edição dez anos depois.

A década de 50 poderia ser considerada um período de inflexão na trajetória de Arciniegas. Exilado e radicado nos Estados Unidos como professor universitário, Arciniegas investiu em dois campos: a história da renascença na Itália quatrocentista e a crítica da política latino-americana. O primeiro desses assuntos tinha relação com a "descoberta de América", tema tratado anteriormente pelo escritor em vários de seus ensaios. O segundo foi a reação de quem jamais esteve alheio à política, frente à ascensão de governos autoritários em vários países, a começar pela Argentina, que deixaram de lado os ideais liberais e excluíram das posições de poder colegas, amigos e colaboradores do escritor, fossem jornalistas, políticos ou escritores, inclusive o próprio Arciniegas. Entretanto, a publicação de um novo livro sobre a história e a cultura da América Latina, América Mágica, teve que aguardar até 1959, embora fora oferecido ao editor desde 1950, o que mostra bem o adiamento desse projeto a favor de outros investimentos. Tal década pode-se considerar definitiva também em relação aos vínculos com os editores argentinos, pois em 1951 Arciniegas já havia anunciado a López ser ele seu “editor definitivo” em língua castelhana $^{264}$.

\footnotetext{
${ }^{261}$ Antonio López Llausás a G.A., 07/01/1955, BNC, FGA, Caja 20, Carpeta 8. Segundo testemunho do Arciniegas, este livro foi concebido no marco das conferências ministradas na Universidade de Chicago. Teve tradução para o inglês logo em 1946, The Caribean sea of the New World. Ian Randle Publishers. É o livro de Arciniegas traduzido ao maior numero de línguas.

${ }^{262}$ Antonio López Llausás a G.A., 07/09/1947, BNC, FGA, Caja 20, Carpeta 5.

${ }^{263}$ Antonio López Llausás a G.A., 03/09/1947, BNC, FGA, Caja 20, Carpeta 8. Antonio López Llausás a G.A., 07/09/1947, BNC, FGA, Caja 20, Carpeta Editorial Losada.

${ }^{264}$ Llausás se sentía "Muy agradecido a sus atenciones ya que me considera su editor total y definitivo". Antonio López Llausás a G.A., 29/01/1951, BNC, FGA, Caja 20, Carpeta 8.
} 
No aguardo de América Mágica, López Llausás recebeu em 1951 o anúncio de um livro sobre Américo Vespuccio. A exclusão do poder sofrida pelos liberais colombianos desde 1946 resultava rentável para López: "Me alegra verle tan metido en cuestiones literarias en estos momentos en que sus actividades diplomáticas deben estar un poco en suspenso"265, "me agradaría mucho repetir el éxito que hemos tenido con la "Biografía del Caribe" cuya nueva edición tengo ya en prensa"266. Todavia, as dificuldades que atravessava a indústria editorial argentina nestes anos fizeram com que López Llausás propusesse editar o novo livro no México, na editora Hermes, da qual era "socio y dirigente". Assim se fez, e Amérigo y el Nuevo Mundo apareceu na Cidade do México, em $1955^{267}$.

Como resultado das temporadas de pesquisa na Itália, Arciniegas redigiu mais dois livros. Um estudo sobre Simonetta Vespuccio e o que ele chamou de "guia literária de pequenos lugares italianos". Este, Italia, guía para vagabundos, apareceu em 1957 em Buenos Aires, enquanto El mundo de la bella Simonetta teve que aguardar até 1962.

O livro de crítica política Entre la libertad y el miedo teve uma história mais longa e complicada, que revela a natureza e os limites da colaboração entre o escritor e seu "editor definitivo". Oferecida desde 1951, foi rejeitada em vista das possíveis consequências que trariam para a empresa as opiniões adversas ao governo de Perón consignadas no livro do colombiano. López Llausás tampouco propôs a edição pela Hermes, pois essa tinha sucursal em Buenos Aires e também sofreria retaliações ${ }^{268}$. Ao mesmo tempo, Arciniegas rejeitou a proposta da Emecé para publicá-lo em Buenos Aires, e argumentava que via "como única posibilidad la de editarlo en México por alguna casa que no haya de percibir algún perjuicio por la reacción que pudiera producirse de parte de algunos gobiernos ${ }^{269}$ ". O livro foi publicado pela editora Cuadernos, associada à revista Cuadernos Americanos, da qual o colombiano era assíduo colaborador, além de amigo do diretor Jesús Silva Herzog. Entre la libertad y el miedo obteve una ampla acolhida. Foi reeditado no Chile em cinco ocasiões pela Editorial del Pacífico -com atualizações sucessivas

\footnotetext{
265 Antonio López Llausás a G.A., 29/01/1951, BNC, FGA, Caja 20, Carpeta 8.

266 Antonio López Llausás a G.A. 10/01/1951, BNC, FGA, Caja 20, Carpeta 8.

267 Antonio López Llausás a G.A. 31/10/1952, BNC, FGA, Caja 20, Carpeta 8; Antonio López Llausás a G.A., 16/12/1952, BNC, FGA, Caja 20, Carpeta 8; Antonio López Llausás a G.A., 04/03/1953, BNC, FGA, Caja 20, Carpeta 8.

${ }^{268}$ Antonio López Llausás a G.A., 09/01/1952, BNC, FGA, Caja 20, Carpeta 8.

${ }^{269}$ GA a Carlos V. Frías, 28/04/1952. BNC, FGA, Caja 1, Carpeta 17.
} 
que davam conta da evolução político-regional-. Finalmente, a queda de Perón em 1956 permitiu a publicação em Buenos Aires, que Sudamericana acelerou para fazê-la coincidir com a visita do escritor à cidade, convidado do general Aramburu para a posse presidencial ${ }^{270}$. O livro que já tinha sido um sucesso comercial, o foi de novo, mas desta vez os ganhos foram novamente para o editor catalão.

A rejeição inicial desse livro não obedeceu somente a razões políticas, mas também comerciais. A propósito de outra rejeição, Jorge López Llovet, filho de López Llausás, explicava a Arciniegas:

"El asunto de Herbert Mathews ${ }^{271}$ se lo pasé a Urgoiti, que lo está estudiando, pero le anticipo que con excepción de libros del tipo de "LA NUEVA CLASE" o de su "ENTRE LA LIBERTAD Y EL MIEDO", (que es una rara y notable excepción,) que van acompañados por una prensa tan abundante que hacen que la venta esté asegurada, estamos muy desengañados de los libros de política, pues tienen una vida tan efímera que nos hemos enganchado los dedos más de una vez"

Urgoiti deu o "não" final ao livro de Mathews sobre a Guerra Civil Espanhola, sugerido por Arciniegas, explicando: a censura franquista já punha obstáculos à circulação dos livros da editora e com essa publicação o assunto poderia se complicar mais ${ }^{273}$.

No contexto da "Revolução Libertadora", os editores de Arciniegas se sentiram mais confiados e otimistas. Houve edição argentina de Amérigo y el nuevo mundo -Arciniegas estava descontente pela qualidade da edição mexicana- e apareceu também Italia, guía para vagabundos. López Llausás recebeu por fim o manuscrito de América Mágica, que publicou em dois volumes, apontando as características americanistas do livro: "Me alegro que haya terminado el manuscrito de AMERICA MAGICA, pues ya sabe que es un libro en el que tengo una gran confianza porque el contenido puede ser de mucho interés para los países americanos y porque el título es un verdadero acierto" 274 . Com efeito, dois volumes de retratos de doze homens e doze mulheres de diferentes épocas e países da América Latina, era material adequado à vocação

270 Julián Urgoiti a G.A., 12/03/1958, BNC, FGA, Caja 20, Carpeta 8; Antonio López Llausás a G.A. 19/03/1958, BNC, FGA, Caja 20, Carpeta 8.

${ }^{271}$ Jornalista do New York Times na invassão italiana em Etiopia, na Guerra Civil Espanhola e que tomou entrevista com Fidel Castro na Serra Maestra em 1957.

272 Jorge López Llovet a G.A. 19/11/1957, BNC, FGA, Caja 20, Carpeta 8.

273 Julián Urgoiti a G.A., 17/12/1957, BNC, FGA, Caja 20, Carpeta 8. Sobre a censura franquista em relação aos autores colombianos, ver: Bermúdez Liévano, Andrés. "La literatura colombiana bajo la lupa del franquismo". Arcadia, 03/09/2011. Quase todos os livros de Arciniegas superaram a censura, mas Bermúdez especifica quais deles não.

${ }^{274}$ Antonio López Llausás a G.A., 16/07/1958, BNC, FGA, Caja 20, Carpeta 8. 
exportadora que tinha a editora, além de muitos dos personagens representarem a tradição política liberal defendida pelo escritor. Além disso, com sensibilidade profissional, López Llausás tinha elogiado o título desde seu anúncio uma década antes, sugerindo ainda registrá-lo, embora o manuscrito não estivesse pronto.

Nesse novo ambiente, foram reeditadas ainda duas obras: América, tierra firme, que esteve até então em mãos de Losada, e a segunda edição de En medio del camino de la vida, o romance de vendas baixas. Escreveu López Llausás : "Ya ve que no soy de los que dejan abandonados los libros que se agotan, pues incluso los menos vendidos, intentamos que se vendan más creando colecciones como la "Piragua" para ver si a menor precio el público los compra"275. Finalmente, houve uma reedição de El estudiante de la mesa redonda, mas fora da Argentina, em outra empresa da qual López Llausás era sócio, Edhasa, de Barcelona.

As vicissitudes econômicas e políticas que levaram a Sudamericana a publicar as obras de Arciniegas no México e na Espanha foram também motivo de seu intercâmbio epistolar. Suas inquietações pelo desenvolvimento da indústria e o mercado editorial na região refletem o encontro dos projetos autorais do escritor com as projeções culturais e comerciais dos editores.

\section{Mercado latino-americano do livro.}

Germán Arciniegas foi editor na Bogotá dos anos 1920 e como Ministro de Educação na década de 1940 tomou parte nas iniciativas oficiais de promoção da leitura e da formação de um público leitor na Colômbia. Arciniegas, portanto, não foi alheio à sorte da indústria editorial no país e, como outros intelectuais comprometidos com um projeto de entendimento e integração regional, considerou fundamentais o intercâmbio literário e a circulação de livros para fortalecer os vínculos americanos. Era natural que os obstáculos que tiveram esses propósitos permeassem a correspondência com seus editores.

A preocupação com esses assuntos já era notória desde o começo dos anos 1940. Durante seus anos de exercício diplomático em Buenos Aires, Arciniegas havia se queixado diretamente com o

275 Antonio López Llausás a G.A., 03/03/1958, BNC, FGA, Caja 20, Carpeta 8. 
presidente da Colômbia Eduardo Santos pelo aumento dos impostos de importação de impressos ${ }^{276}$. Em 1942, já como Ministro, Arciniegas pediu à Losada para distribuir a "Biblioteca Popular Colombiana", coleção planejada por Arciniegas para publicar uma seleção da tradição literária nacional ${ }^{277}$. Gonzalo Losada aceitou, celebrando a iniciativa:

"Como es Ud. un auténtico hombre de letras, su paso por el Ministerio de Instrucción Pública de su país, tenía que dejar una huella de este orden y yo confío en que la huella sea honda y duradera."

"Desde luego puede Ud. contar con nuestra cooperación más decidida para hacer conocer los libros de la Biblioteca en la Argentina y el Uruguay, países que trabajamos nosotros directamente, bien a fondo, pues si no existieran otras razones, que existen muchas, una de las misiones que nos hemos impuesto, es la de contribuir por todos los medios a nuestro alcance, a la difusión de todos los buenos libros que se produzcan en América, incluyendo los de Universidades, Institutos Culturales etc."

Losada expressou que mantinha acordos semelhantes junto às universidades argentinas e com o Fundo de Cultura Econômica, o que assinala o lugar da editora nos processos de articulação continental e na promoção de novos discursos sobre a sociedade, produzidos desde as universidades, onde se nucleavam nestes anos, na Argentina, importantes grupos reformistas e liberais $^{278}$. A cooperação entre a editora mexicana e a argentina, as quais tinham acolhido um número importante de exilados espanhóis, sublinha o caráter ideológico da empresa cultural liderada por Losada e pode indicar também a complementariedade que mantinham naquele momento: o FCE publicava mais ciências sociais e Losada mais narrativa ${ }^{279}$. É claro que o lugar mais apropriado para os livros de Arciniegas estaria justamente na casa portenha.

A visão americanista de Losada, "la difusión de todos los buenos libros que se produzcan en América”, foi viabilizada pela criação de sucursais nos países vizinhos. Visando, como outros colombianos, fazer de Bogotá um “centro editorial” e já como acionista da editora, Arciniegas

\footnotetext{
${ }^{276}$ Germán Arciniegas a Eduardo Santos, 13/12/1940/, BNC, FGA, Caja, 1, Carpeta 4.

${ }^{277}$ Sobre esta série que chegou aos 160 títulos, não existe um estudo monográfico, mas sim sobre uma anterior, e menor, de 100 títulos, e que também foi resultado dos esforços dos governos liberais: a "Selección Samper Ortega" conhecida também como "Biblioteca Aldeana de Colombia". Silva, Renán, "Libros, lecturas y lectores durante la República Liberal” Em: República liberal, intelctuales...Op. Cit. pp, 87-154. É importante salientar que na Colômbia as coleções populares de livros foram principalmente obra do Estado. Ver Cobo Borda, Juan Gustavo, "Historia de la indústria..." Op. Cit, pp 176-182. Neste sentido, existe um contraste notável com a experiência argentina, onde editoras privadas aproveitaram a expansão da alfabetização para a formação de um público leitor nas primeiras décadas do século XX. Ver Gutiérrez, Leandro e Romero, Luis Alberto, Sectores populares, cultura y política. Buenos Aires en la entreguerra. Buenos Aires, Siglo XXI, 2007.

${ }^{278}$ Sobre seu papel na promoção das ciências sociais, ver Sorá, Gustavo, "Ediciones y editoriales de ciências sociales..." Op. Cit. Para a circulação destas edições nos âmbitos colombianos, Cataño, Gonzalo, La introducción del pensamento moderno en Colombia. El caso de Luis Eduardo Nieto Arteta. Bogotá. Universidad Externado de Colombia, 2013.
}

${ }^{279}$ Sorá, Gustavo, “Ediciones y editoriales...” Op. Cit. 
sugeriu a Gonzalo Losada que instalasse uma loja na capital colombiana desde 1944. Em sua resposta, Losada expressou pontos que caracterizam o sentido de seu americanismo editorial e a necessidade de compreender diversas produções e públicos:

\begin{abstract}
"Esta sugestión suya coincide con un firme propósito mío de instalar en Bogotá una filial de nuestra casa pues mi opinión es que para dar a la Editorial un auténtico carácter americano y, si me permite, hispánico, es necesario salir de Buenos Aires. También hay que decir que este procedimiento de las filiales, sucursales, correspondientes o, como queramos llamarlas, es necesario desde un punto de vista comercial, esto es, para que la propia editorial tenga un contacto directo con libreros y público no a través de distribuidores, más o menos capaces y bien intencionados $" 280$.
\end{abstract}

Naquela data, a editora contava com sucursais no Uruguai e no Chile, um "representante con depósito" no Brasil e um projeto de sucursal no Peru. Na mente de Losada, estava a expansão gradual para Venezuela, Cuba, México e Espanha. Se abrisse, a sucursal colombiana deveria repercutir na inclusão de obras nacionais no catálogo da editora, daí que considerasse que "Podría tener una sección editorial para editar estrictamente dos colecciones: una de clásicos colombianos, auténticamente bien hecha, y otra de escritores colombianos contemporáneos" 281. Losada, finalmente, mencionava o assunto do capital e o controle da sucursal. "El capital lo pondríamos nosotros, sin perjuicio de dar alguna participación a Colombia, en las personas de colombianos “auténticos" bien intelectuales o con afinidades culturales, porque de ninguna manera queremos perder nuestra fisonomía"282. Losada "para todo lo referente a la casa Colombiana, principalmente, como Director de la sección editorial”, pensava em Arciniegas, mas “En otro caso, ya me diría usted quien sería el hombre adecuado"283.

Losada viajou para a Colômbia, depois de várias tentativas frustradas, em 1952. As circunstâncias políticas haviam mudado desde 1946, quando os liberais perderam o poder. A violência se espalhava pelo campo e os governos conservadores se orientavam firmemente para o autoritarismo. Como a maioria dos mais notáveis líderes políticos liberais, Arciniegas não permaneceu no país. Nesse contexto, a prudência de Losada no sentido de articular associados locais na empresa foi ainda maior. Assim relatou:

(En Colombia) "Se me recibió magníficamente y encontré toda clase de facilidades, incluso se me ofreció dinero, pero no lo acepté porque prefiero que el ensayo -muy riesgoso por cierto-, sea de nuestra exclusiva responsabilidad. Tiempo habrá para convertir esta filial en sociedad colombiana, con capital colombiano,

\footnotetext{
${ }^{280}$ Gonzalo Losada a G.A., 22/09/1944, BNC, FGA, Caja 20, Carpeta 5.

${ }^{281}$ Ibíd.

282 Ibíd.

${ }^{283}$ Ibíd.
} 
cuando la casa esté, como espero, consolidada y las circunstancias resulten más cómodas para todos pues el momento en su país no puede ser más agrio y enredado y sin perjuicio de nuestra conocida posición ideológica debemos mantenernos, por ahora, equidistantes para no comprometer el intento. Las cosas empiezan a desenvolverse por alli bien pero todavía hay mucho camino que andar"'284

Losada mostrou-se otimista, e não só pela recepção que teve nos círculos letrados, mas pelo sucesso comercial e literário da primeira peça narrativa publicada pela sucursal, El Cristo de espaldas, do escritor, jornalista e político liberal Eduardo Caballero Calderón ${ }^{285}$, que avaliou com "bellísima de estilo, perfecta en arquitectura y de un contenido eminentemente humano" 286 . $\mathrm{Na}$ correspondência disponível, não se encontra mais informação sobre a marcha da sucursal, mas é possível afirmar que em 1958 constavam no catálogo da editora onze livros de autores colombianos $^{287}$.

Por outro lado, Sudamericana nunca abriu uma sucursal em Bogotá. A distribuição de seus livros se fez através de Losada. Embora, já em 1940, a editora tinha pedido a Ots Capdequí informação sobre as possibilidades de estabelecer uma livraria na cidade, o projeto não prosperou. No entanto, o significativo é a disposição que mostrou López Llausás para construir alianças com investidores locais, disposição que não foi além disso, pois o projeto faliu depois que não encontrou um sócio conveniente ${ }^{288}$. A estratégia de expansão de López Llausás, em claro contraste com a de Losada, baseou-se no investimento e na fundação de outras editoras no México e na Espanha (Hermes e Edhasa), justamente onde Losada não chegava diretamente. Se López Llausás sugeria a Arciniegas editar no México na década de 50, já em 1949 buscava estabelecer também base na Espanha, pois "estoy viendo que la política del gobierno argentino nos puede poner en un verdadero aprieto a los editores argentinos si no buscamos la salida de imprimir en otras partes" ${ }^{289}$.

Com efeito, a circulação do livro argentino -e os de Arciniegas eram isso desde o ponto de vista editorial comercial -, teve que enfrentar uma série de circunstâncias desfavoráveis, o que ocasionou a perda da sua liderança regional. Arciniegas e os editores ressentiram a ausência de

\footnotetext{
${ }^{284}$ Gonzalo Losada a G.A., 05/06/1952, BNC, FGA, Caja 20, Carpeta 5.

${ }^{285}$ Caballero Calderón publico também em Losada Ancha es Castilla (1954), mas ele construiu vínculos mais fortes com casas editoriais espanholas

${ }^{286}$ A segunda foi Diario de Estoril del poeta liberal José Umaña Bernal.

${ }^{287}$ Dabusti De Muñoz, María Teresa: “Trayectoria de Lorenzo Luzuriaga...”...Op. Cit.

${ }^{288}$ Antonio López Llausás a G.A., 18/12/1940, BNC, FGA, Caja 20, Carpeta 8.

${ }^{289}$ Antonio López Llausás a G.A., 30/03/1949, BNC, FGA, Caja 20, Carpeta 8.
} 
suas obras em vários países da América Latina, o atraso nos pagamentos dos dividendos e a pirataria. Talvez por causa de sua vinculação acionária na editora, Losada transmitia a Arciniegas repetidamente e com detalhe o avanço da crise da indústria do livro, que começou a lamentar em 1946. López Llausás foi mais conciso, mas ainda assim os problemas do mercado editorial estiveram presentes em sua correspondência.

Desde a Segunda Guerra Mundial, a queixa recorrente era a falta de embarcações para transportar livros e insumos para a edição, pois todos os barcos estavam destinados a produtos mais urgentes. A partir de 1948, somaram-se as restrições oficiais para importar papel, o processo inflacionário $^{290}$ e as greves dos operários do ramo ${ }^{291}$. Isso produz a diminuição da produção, praticamente a estagnação dos catálogos de ambas as editoras e a quase desaparição das coleções populares que, como a "Biblioteca Austral" da editora Espasa e a "Biblioteca Contemporánea" de Losada, haviam sido fundamentais para a formação da indústria editorial e do público leitor argentino ${ }^{292}$. Losada comparou a sorte dessas coleções:

\begin{abstract}
"Cierto que otra editorial, concretamente Espasa Calpe continúa con su colección Austral -creada por nosotros, no hay que olvidarlo- pero ha tenido que subir mucho los precios y, además, mete en ella muchísimas obras del dominio público y otras cuyos derechos son comprados a los autores por cantidades que no llegan al (ilegible) sobre los precios de venta. La verdad en este caso es que como no pueden publicar obras nuevas o interesantes por estar sometidos a la censura española, se concentran en estas publicaciones neutras y heterogéneas, pero nuestra situación es otra, preferimos principalmente editar obras nuevas, no sólo para satisfacer las necesidades de los lectores suramericanos sino también para no fosilizarnos" 293
\end{abstract}

Quatro anos mais tarde, a situação era ainda pior:

"Las alteraciones sufridas en estos últimos años en los precios de las materias primas como papel y telas y en los trabajos industriales como composición e impresión, etc., han sido tan fantásticas que todas las colecciones de carácter más o menos económico quedaron socavadas y a esto se debe el que la Biblioteca Contemporánea, el Pensamiento Vivo, Obras Maestras, que tenían y siguen teniendo un carácter popular y educativo se encuentren, pudiéramos decir, desmanteladas. Forzosamente hubo de dedicarse a la edición de libros de otra naturaleza donde el factor precio no fuera tan fundamental" ${ }^{\prime 294}$.

As rivalidades políticas derivadas da aberta tomada de posição dos editores argentinos contra a consolidação do peronismo desde $1945^{295}$ não contribuíram à solução desses problemas. López

${ }^{290}$ Gonzalo Losada a G.A., 09/02/1949, BNC, FGA, Caja 20, Carpeta 5. Véase también: Larraz, Fernando, Una historia trasatlántica del libro. Relaciones editoriales entre España y América Latina (1936-1950). Gijón, Trea, 2010.

${ }^{291}$ GIULIANI, Alejandra. Libros o alpargatas...Op. Cit.

${ }^{292}$ LARRAZ., Fernando, Una historia... OP. Cit.

${ }^{293}$ Gonzalo Losada a G.A., 05/06/1952, BNC, FGA, Caja 20, Carpeta 5.

${ }^{294}$ Gonzalo Losada a G.A, 29/03/1956, BNC, FGA, Caja 20, Carpeta 5.

${ }^{295}$ Giuliani, Alejandra. "Libros o alpargatas....” Op. Cit. 
Llausás e Losada informaram a Arciniegas sobre esses movimentos, pois encontraram nele um interlocutor solidário. Aos problemas já listados, vieram se acrescentar depois as restrições aos movimentos de divisas, que fizeram impossível o pagamento de honorários e dividendos para fora da Argentina ${ }^{296}$. Para cumprir com os pagamentos a Arcinegas, os editores recorreram a diferentes estratégias: Sudamericana às casas associadas. "La única salvación es la que hemos adoptado con Madariaga, o sea transferir a "Editorial Hermes", la reedición de las obras que se van agotando. ${ }^{297}$, escrevia López Llausás, “con la ventaja de que desde allí no hay ninguna dificultad para el pago de las regalías" ${ }^{298}$. No caso de Losada, se tentou também pagar a um representante do escritor em Buenos Aires e realizar as cobranças nas sucursais de Lima ou Bogotá $^{299}$. Ainda assim, a maior parte dos pagamentos foram se acumulando até o fim do período peronista.

Essa circunstância fez também com que se estabelecessem restrições às importações de livros argentinos em países como México e Chile, como resposta aos atrasos nos pagamentos das importações $^{300}$. O caso mais preocupante foi o do México, mercado e terreno cultural fundamental para as editoras e o escritor. López Llausás disse:

"Es posible que en estos últimos tiempos haya faltado alguno de nuestros libros en México. Esto se debe a que el amigo Cossío Villegas, al no poder cobrar de la Argentina, los libros del Fondo que allí mandaba, por la causa de escasez de dólares de todos conocida, sugirió y logró que el gobierno mexicano, castigara con un impuesto muy grande, los libros de importación argentina, que hacía casi prohibitivo el precio a que tenían que venderse, lo cual facilitaba y estimulaba de retruque la piratería mexicana"301.

\footnotetext{
${ }^{296}$ Gonzalo Losada a Germán Arciniegas, 09/02/1949, BNC, FGA, Caja 20, Carpeta Editorial Losada. Era o caso de Arciniegas e especialmente das editoras chilenas e mexicanas.

297 Antonio López Llausás a G.A, 23/03/1954, BNC, FGA, Caja 20, Carpeta 8.

298 Antonio López Llausás a G.A., 31/10/1952, BNC, FGA, Caja 20, Carpeta 8

${ }^{299}$ Gonzalo, Losada a G.A., 29/03/1956, BNC, FGA, Caja 20, Carpeta 5. Em uma ocasião, o filho de López Llausás entregou na Europa 500 dolares a Arciniegas, que o escritor agradeceu ao editor, buscando sigilo, como os " 500 livros" enviados desde Buenos Aires.

${ }^{300}$ Antonio López Llausás a G.A., 31/01/1957, BNC, FGA, Caja 20, Carpeta 8: "Sus lamentaciones de que no se encuentran sus libros en Chile no me sorprenden pues hace más de dos años que no podemos mandar un libro allí. Es otra cosa parecida a la de México que cada día nos dan la esperanza de que va a resolverse, pero no se resuelve nunca".

301 Antonio López Llausás a G.A., 07/07/1950, BNC, FGA, Caja 20, Carpeta 8. Daniel Cossío Villegas foi fundador e diretor do Fundo de Cultura Econômica até sua morte, quando foi sucedido pelo argentino Arnaldo Orfila Reynal, que tinha sido diretor da primeira sucursal da editora, localizada em Buenos Aires desde 1945. Na coleção de maior orientação "americanista", "Tierra Firme", Arciniegas tomou parte com Este Pueblo de América (1945), coletânea de ensaios sobre a história americana, que tinham sido publicados entre 1940 e 1941 em jornais e revista argentinas. Foi também o assessor de Cossío para conseguir e selecionar os colaboradores para essa coleção; e para escolher o representante do FCE em Bogotá, quando o próprio Arciniegas foi morar nos Estados Unidos. Junto com Este pueblo de América, Cosas del Pueblo (Hermes, 1956), Entre la libertad y el miedo (Cuadernos, 1952) y Amérigo y el Nuevo Mundo (Hermes, 1954), são todos os livros publicados por Arciniegas originalmente no México.
} 
Em vão os editores argentinos, já agremiados, pediram ao governo que negociasse acordos. Só faltava, como assinalava López Llausás, a aparição da pirataria que se espalhava pelo México e pelo Caribe. Desde 1948, se menciona que os livros de Arciniegas estão sendo "pirateados". Através das diligências de Hermes, López Llausás e Arciniegas buscaram combater e castigar a editora Diana, responsável pelo dano comercial que, muito embora, facilitou a circulação da obra do colombiano.

O caso é interessante porque atenta para o fato do autor não estar interessado apenas na divulgação de sua obra, para a qual a pirataria seria uma aliada eficiente, mas em receber os lucros da venda de seus best-sellers: El estudiante de la mesa redonda, Biografia del Caribe e Entre la libertad y el miedo. O apelo comercial do escritor era complementado, naturalmente, pelo do editor. López Llausás festejava o fato de Arciniegas ter deixado os cargos administrativos nos governos liberais da década de 40, pois dessa maneira pudera se dedicar às atividades literárias com maior continuidade; atividade intensa que já no começo da sua relação tinha sido ressaltada pelo próprio editor como excepcional no mundo dos escritores. As atividades de mediação cultural que couberam assim ao setor editorial estavam atravessadas e limitadas pelo viés comercial, que estimulava a autocensuras do editor temendo a interdição de mercados como o espanhol e o argentino (foram os caso de Entre la libertad y el jmiedo, e os livros de Ezquenazi Mayo e Herbert Mathews propostos pelo escritor como possíveis publicações). Do mesmo modo o viés comercial limitava a expansão do catálogo e ainda definia preferências, em momentos de crise, por produtos mais comerciais, antes que à ideologias ou inclinações estéticas dos empresários culturais.

Depois da queda de Perón, foram retiradas algumas das restrições à importação de insumos e ao movimento de divisas para o exterior. Como foi dito acima, o novo período imprimiu otimismo nos editores que se dispuseram a recuperar o espaço que a indústria editorial argentina havia perdido nos últimos anos, como disse Arciniegas. E as condições agora pareciam bastante melhores, pois como escreveu López Llausás a respeito da edição argentina do Amérigo, em virtude da desvalorização do peso,

"si hacemos una edición aquí podremos venderla a la mitad del precio de la mexicana, puesto que estamos en mejores condiciones que nadie para exportar libros, que con el cambio libre saldrán muy baratos en cualquier país del área del dólar, y tampoco hay a partir del 30 de junio de este año, o mejor dicho de todos 
los compromisos que se adquirieron a partir de esa fecha, ningún inconveniente para la transferencia de fondos a los autores ${ }^{\prime 302}$.

Todavia, novos problemas se desprenderam desse cenário em princípio favorável, pois os editores tiveram que se enfrentar agora com as várias medidas protecionistas que muitos países da região começaram a implementar. Para superar essa situação, López Llausás apelou de novo à estratégia de publicar nas outras casas das quais era sócio:

"Con su ESTUDIANTE DE LA MESA REDONDA que tengo ya en pruebas pienso hacer lo siguiente: Edhasa de España hará por medio de su sucursal en Buenos Aires la edición. Esta edición la trabajará la Sudamericana como propia puesto que somos los representantes de Edhasa en Argentina. En esta edición no pondremos pie de imprenta argentina y los libros destinados a México los remitiremos a España, para que desde alli y con edición española, puesto que el pie será "Edhasa"-Barcelona-Buenos Aires, los reexpidan a México. Total la vuelta al mundo para entrar a México, pero espero que así por lo menos, podamos lograrlo. ${ }^{303}$.

López Llausás preferia isso à realizar uma edição através de Hermes, não só porque já tinha o livro quase pronto em Buenos Aires, mas porque

"no es posible hacer una edición en México, ya que el alto costo de la confección del libro allí, por ser país de moneda fuerte, lo pondría en malas condiciones para distribuirla y exportarla desde México, cuyo consumo local por otra parte, no absorbe una edición ni de tres mil ejemplares ${ }^{\text {"304. }}$.

Em diversas ocasiões, Arciniegas escreveu a seus editores, inquietado pela ausência de seus livros nas livrarias do Chile, México, Cuba e Colômbia, o que ele próprio havia constatado em suas viagens ${ }^{305}$. Em alguns casos, esse desabastecimento foi causado por medidas alfandegárias, mas em outros, como a própria Colômbia, havia outros fatores. "En Colombia teníamos concedida la exclusiva de distribución al amigo Losada que tiene sucursal en Bogotá, pero habiendo comprobado que estaba muy descuidada la venta de nuestros libros, recabamos poder servir los pedidos que nos hicieran directamente los clientes" 306 , pedidos principalmente de Biografía del Caribe y Amerigo y el Nuevo Mundo. Com respeito a Entre la libertad y el miedo,

\footnotetext{
302 Antonio López Llausás a Germán Arciniegas, 17/11/1955, BNC, FGA, Caja 20, Carpeta Editorial Sudamericana.

303 Antonio López Llausás a G.A., 06/03/1957, BNC, FGA, Caja 20, Carpeta 8. Arciniegas vinculou-se depois a outras empreitadas editoriais espanholas por meio de seus contatos portenhos. Foi o caso da coleção El Puente e da revista homônima, dirigida por Guillermo de Torre entre 1963 e 1968. Os textos de Arciniegas sofriam então a proibição de entrada, ordenada pela censura franquista. Gergardt, Federico, "Todos los puentes El Puente. Una colección en tres épocas". Olivar, V.12, N. 16, 2011, pp. 241-283.

${ }^{304}$ Antonio López Llausás a G.A., 06/03/1957, BNC, FGA, Caja 20

${ }^{305}$ Antonio López Llausás a G.A, 05/12/1956, BNC, FGA, Caja 20, Carpeta 8; Julián Urgoiti a G.A., 12/03/1958, BNC, FGA, Caja 20, Carpeta 8; Antonio López Llausás a G.A., 12/03/1959, BNC, FGA, Caja 20, Carpeta 8.

${ }^{306}$ Antonio López Llausás a G.A., 05/12/1956, BNC, FGA, Caja 20, Carpeta 8.
} 
López Llausás afirmava que os livreiros "tienen miedo de recibirlo"307. Ainda livrarias como a “Camacho Roldán” mostravam reticências para receber os livros de Arciniegas ${ }^{308}$.

Esse estado de coisas fez com que fosse lenta a recuperação da indústria editorial argentina, que desde seu crescimento na década de 1930 havia tido marcada vocação de exportação. Julián Urgoiti escreveu a Arciniegas em outubro de 1959: "el mal ejemplo cunde y ahora nos anuncia el Consulado de Cuba la implantación de un recargo en forma de factura consular. No le parece que los países de América están empeñados en darse la espalda? "309

\section{Conclusões}

Germán Arciniegas estabeleceu vínculos com as editoras portenhas Losada e Sudamericana durante seus dois anos de residência em Buenos Aires como funcionário diplomático, que lhe permitiram ter o campo editorial dessa cidade como um lugar de projeção que foi fundamental para sua consagração continental. O marco dessa efetiva junção de autor e editores, que se manteve por décadas, foi a função das empresas como espaço de sociabilidade da intelectualidade liberal local, ponto de encontro de espanhóis, argentinos e outros latino-americanos e europeus, espaço de recepção de exilados e viajantes comprometidos com a cultura e a defesa dos valores republicanos e do liberalismo durante os anos da Segunda Guerra Mundial e os dez anos seguintes $^{310}$.

Para ressaltar o grau de afinidade que houve entre Arciniegas e seus editores argentinos, vale a pena mencionar a antipatia de outros autores para com o proprietário da Sudamericana, Antonio López Llausás, considerado um avarento, um “catalán asqueroso" em palavras de Julio Cortázar $^{311}$. Com efeito, a coincidência entre Arciniegas e os editores de Sudamericana em questões comerciais os levou a trabalhar conjuntamente na luta contra as edições piratas no

\footnotetext{
${ }^{307}$ Ibíd.

${ }^{308}$ Librería Camacho Roldán a Editorial Sudamericana, 07/10/1959, BNC, FGA, Caja 20, Carpeta 8; Julián Urgoiti G.A., 02/10/1959, BNC, FGA, Caja 20, Carpeta 8; Julián Urgoiti a G.A. ,22/10/1959/, BNC, FGA, Caja 20, Carpeta 8; Julián Urgoiti a G.A., 01/01/1960, BNC, FGA, Caja 20, Carpeta 8.

309 Julián Urgoiti a G.A., 30/10/59/, BNC, FGA, Caja 20, Carpeta 5.

${ }^{310}$ Assim o assinalou Neiburg seguindo a trajetória de Gino Germani. Neiburg, Federico, Los intelectuales y la invención...Op. Cit.

311 De Diego, José Luis. “Cortázar y sus editores”. Orbis Tertius. Vol. 14, No. 15, 2009. Cortázar tinha sido secretario da agremiação dos esditores no final da década de 1940, onde Llaúsás y Losada tiveram um papel destacado de lideranças, pressionando o governo para facilitar as exportações de livros.
} 
México e no Caribe, e foi fundamental para consolidar sua relação além dos aspectos ideológicos e dos projetos literários que tanto o autor quanto os editores puderam ter, convergindo neles ou não.

Voltando a esse último aspecto, o ideológico, podemos mencionar o fato de Arciniegas não publicar nunca na editora Siglo XXI, fundada na década de 1950 por Arnaldo Orfila Reynal, quem fora liderança estudiantil da Reforma Universitária dos anos 1920, o primeiro diretor da sucursal bonaerense de Fondo de Cultura Econômica, e o segundo diretor geral dessa editora, e portanto próximo do escritor com quem mantinha, ainda, correspondência. Siglo XXI adotou um compromisso profundo com a intelectualidade crítica e revolucionária do continente, em rejeição recíproca com o próprio Arciniegas ${ }^{312}$. A importância da dimensão ideológica nas relações autoreditor, é gritante no incômodo de Arciniegas com seus editores chilenos da ZIG-ZAG, já em 1941, por conta da capa para Los Comuneros, que mostrava um punho fechado. Em opinião do autor, a capa "le dá um carácter al libro, polémico, que seguramente va a restringir su circulación y las simpatías que pudiera despertar la obra", pois "Aunque el libro es el relato de un movimento tipicamente revolucionário, su caracter genuinamente americanose falsea con el puño cerrado que ha hecho el dibujante" ${ }^{313}$.

A solidariedade ideológica esteve, assim, na base dessa estreita e longa relação, reforçada por projetos culturais afins. A vocação exportadora dessas empresas e sua intenção de publicar obras originais de autores americanos foram condizentes com a orientação americanista da produção intelectual do escritor. Mostramos como foi pela estrutura continental de distribuição dessas editoras que Arciniegas conseguiu aproveitar melhor o momento de intercambio e integração intelectual experimentado na primeira metade do século XX. A fraqueza da indústria editorial colombiana fez com que o caso de Arciniegas fosse excepcional. Ainda na década de 1970 afirmava Tito Lívio Caldas que:

"Mientras el país no posea editoriales de prestigio que dispongan como condición muy llamativa para el escritor, de canales internacionales de distribución, ni García Márquez,

\footnotetext{
${ }^{312}$ Sorá, Gustavo. "Edición y política. Guerra Fría en la cultura latinoamericana de los años '60”. Revista del Museo de Antropología. Universidad Nacional de Córdoba. No. 1. 2008.

${ }^{313}$ G.A. A Editorial ZIG-ZAG, 23/04/1941. BNC, FGA, Caja 1, Carpeta 5.
} 
ni Germán Arciniegas, ni Caballero Calderón, ni ningún otro escritor de renombre, o que aspire a tenerlo, podrán editar sus obras en el país"314

A fraqueza das editoras colombianas era reconhecida pelo próprio Arciniegas que tentou criar vínculos entre escritores colombianos e a indústria portenha. Mas interessa também assinalar que, nessas condições, o patrocínio oficial era fundamental para os escritores colombianos, o que também se faz manifesto na publicação estatal de coleções populares ${ }^{315}$, em contraste com a Argentina as novidades e as coleções de divulgação correram no circuito das empresas privadas. Arciniegas teve assim uma experiência privilegiada, contando com o estímulo oficial para a edição de várias de suas primeiras obras, mas também como alto funcionário e diretor de revistas e coleções oficiais em seu país.

Por outro lado, poderia se afirmar que, em boa parte, as incursões de Arciniegas nas indústrias editoriais mexicanas e espanholas estiveram mediadas pelo vínculo com as editoras bonaerenses. Nesse sentido, pode se considerar que o encontro entre os projetos do escritor e os planos dos editores foi favorável à formação de um tecido intelectual continental, ainda se sobrepondo às dificuldades que as vicissitudes da política comercial lhes impuseram.

Mas, além das obras de Arciniegas, a colaboração entre as empresas e o escritor favoreceu a circulação de textos da editora argentina nas revistas colombianas, a distribuição de coleções oficiais de literatura colombiana nas livrarias argentinas, a instalação da sucursal de uma das editoras mais importantes do cenário hispano-americano em Bogotá e, ainda, a edição de alguns poucos autores colombianos, que, como Arciniegas, sempre foram funcionários e políticos liberais. Em todas essas trocas, ocorreram funções de "seleção" e "marcação" dos produtos que circulavam: o autor sob o selo da editora, os livros da editora nas páginas da revista, a indicação de determinados autores para determinadas editoras e coleções. Arciniegas também agiu como guia dos editores para assuntos relativos à Colômbia. Foi consultado sobre personagens da história da cultura do país e a pertinência de sua presença nas coleções de Losada, sobre os benefícios de se anunciar as novidades editoriais em um jornal conservador do país e sobre possíveis candidatos para redigir capítulos de história da Colômbia em obras coletivas projetadas pela mesma editora.

\footnotetext{
${ }^{314}$ Caldas, Tito Lívio. Industria editorial, cultura y desarrollo em Colombia. Bogotá. Minerva. 1970, p. 29.

315 Vanderhuck Arias, Felipe, La literatura como oficio... Op. Cit.
} 


\section{Capítulo 4. Argentina traduzida por Germán Arciniegas.}

Introdução

Germán Arciniegas realizou em sua longa vida uma obra imensa, focada na interpretação da experiência histórica e cultural americana. A perspectiva americanista foi o traço mais característico da identidade intelectual de quem, além de cerca de sessenta livros, publicou também numerosos prólogos e artigos para revistas e jornais. Arciniegas escreveu em quase todos os gêneros: alguns poemas iniciais, uma tardia peça de teatro, um romance... Mas os gêneros mais cultuados por ele foram o ensaio e as crônicas de viagem. Hoje é reconhecido como ensaísta e, de fato, foi com esse gênero que obteve a maior atenção da crítica ${ }^{316}$. Assim, o diálogo entre esta face da sua produção literária e os relatos de viagem ainda está à espera ser esclarecida.

Arciniegas publicou memórias, relatos e crônicas de suas viagens e temporadas de residência na Itália, Romênia, Israel, Estado Unidos, o Caribe e ainda alguns países da África ${ }^{317}$, mas nada sobre as visitas que fez aos países da América Latina continental ${ }^{318}$. Todavia, seus escritos de viagem não foram coletados sempre em livros: nos artigos semanais, que o escritor redigia para o

${ }^{316}$ COBO BORDA, Juan Gustavo (compilador). Una visión de América. La obra de Germán Arciniegas desde la perspectiva de sus contemporáneos. Bogotá. Instituto Caro y Cuervo, 1990.

${ }^{317}$ Diario de un peatón, Bogotá, Imprenta Nacional, 1936; En el país del rascacielos y las zanahorias, Bogotá, 1945, 2 volúmenes; Italia, guía para vagabundos, Buenos Aires, Editorial Sudamericana, 1957; Entre el mar rojo y el mar muerto: Guía de Israel, Barcelona, EDHASA, 1964; Medio mundo entre un zapato, Buenos Aires, Editorial Sudamericana, 1969; Nueva imagen del Caribe, Buenos Aires, Editorial Sudamericana, 1970; Roma secretísima, Madrid, Anaya, 1972; Estancia en Rumania, Bucarest, Pentru Turism, 1974.

${ }^{318}$ Recentemente foi publicada uma coletânea com artigos desse tipo referentes ao Paraguay. Arciniegas, Germán, Estampas del Paraguay. Bogotá. Uniandes. 2015. 
jornal bogotano El Tiempo, também encontra-se o registro dessas viagens. Nas palavras do crítico Juan Gustavo Cobo Borda, Arciniegas foi "un periodista que trae el mundo al rectángulo de su columna" ${ }^{319}$. Este capítulo se debruça sobre os artigos de viagem relativos à Argentina, que segundo um útil catálogo das obras do autor foram 34, publicados entre 1939 e $1959^{320}$, a maior parte deles durante sua temporada portenha, como funcionário diplomático entre 1939-194121. A tradução da cidade, mediação cultural.

Durante os dois anos de residência em Buenos Aires e em algumas ocasiões posteriores, Arciniegas "traduziu" a cidade de Buenos Aires e a vida argentina para o público colombiano através de sua coluna de opinião no jornal El Tiempo ${ }^{322}$. Praticante paradigmático da mediação cultural, o escritor dos relatos de viagem se enfrenta à tradução do "outro", apelando a diferentes estratégias e "mecanismos de inteligibilidade" que permitem reduzir a complexidade da novidade ao universo "do conhecido", "transformando a diferença em algo passível de ser assinalado, mensurado e dominado" 323 .

Aspectos os mais variados de Buenos Aires - urbanismo, paisagem rural dos arredores, espaços de lazer, vida intelectual e artística - ocuparam a atenção do escritor colombiano. Essa variedade de motivos para a escrita, cultuada por Arciniegas em suas crônicas da década de 1930, é natural na escrita do viajante, pois "toda escritura viajera es un lugar de convergencia y dispersión de saberes: fuga de un centro y profusión temática son sus características más constantes. Una buena parte de esta escritura se caracteriza por su estructuración episódica, su resolución en el

319 COBO BORDA, Juan Gustavo. Germán Arciniegas. En: Silva, Arciniegas, Mutis, García Márquez y otros escritores colombianos. Biblioteca Familiar de la presidencia de la República. 1997. P. 189.

${ }^{320}$ PABÓN PÉREZ, Hugo Leonardo, Bibliografía de y sobre Germán Arciniegas. Bogotá. Instituto Caro y Cuervo. 2001.

${ }^{321}$ Inspira-me a idéia que nesses artigos pode-se perceber faces do pensamento de Arciniegas que não aparecem em seus livros e que, além disso, pode-se obter através de sua leitura uma compreensão detalhada e profunda da formação de imagens centrais à sua interpretação da história e da cultura da América.

322 MOLlOY, Silvia. Ciudades traducidas: Nueva York en Victoria Ocampo. Prismas. Revista de historia intelectual, No. 6, 2002, p. 65-77; y GORELIK, Adrián. A Buenos Aires de Ezequiel Martínez Estrada. Tempo Social. São Paulo, V. 21, No. 2, 2009. Segundo Gorelik, nos últimos anos tem crescido "o reconhecimento da riqueza do ensaísmo cultural, não só por sua capacidade de captar processos de produção simbólica da cidade, que são, inclusive, fundamentais para a compreensão da dinâmica sociourbana, como por sua criatividade configuradora, sua inventividade para apresentar figuras simbólicas que atuam no imaginário social, traduzindo a cidade, convertendo a realidade metropolitana em conhecimento social". Ibíd, p. 37.

${ }^{323}$ BAGGIO, Kátia Gerab, "A utilização de relatos de viagem como fontes históricas para investigar os intercâmbios intelectuais entre o Brasil e a América Hispânica", en BOHOSLAVSKY, Ernesto, GEOGHEGAN, Emilce y GONZÁLEZ, María Paula (coords.), Los desafíos de investigar, enseñar y divulgar sobre América latina. Actas del taller de reflexión TRAMA. Los Polvorines, Universidad Nacional de General Sarmiento, 2011. 
camino, su propensión a la digresión"324. A leitura dessa heterogeneidade (dispersa, desigual) proposta neste capítulo visa encontrar alguns pontos de gravidade e elucidar nós problemáticos de sua reflexão sobre as características da nação argentina, sua cultura e sua história.

Os relatos têm algumas singularidades que é pertinente salientar. Ainda que constem de uma dimensão memorialística, não são memórias strictu sensu, pois embora a experiência pessoal seja reelaborada na escrita, os textos foram redigidos quase no momento que aconteceu a experiência narrada. Esses relatos tampouco são $\operatorname{cartas}^{325}$, mas artigos de jornal, que visam atingir um público amplo. Nesse sentido o relato de viagem se potencializa com a força da imprensa, um "aparato coletivo de mediação" que opera em duas escalas: entre o exterior e o público local, entre os agentes mais prestigiados do mundo letrado e o público curioso ${ }^{326}$. Mas este formato jornalístico não implicava o anonimato do repórter; pelo contrário, os artigos assinados por Arciniegas contribuíram à formação do nome do autor e salientaram seu papel como mediador, permitindolhe abranger um público maior do que o de seus livros ensaísticos ${ }^{327}$. O sentido pedagógico dos relatos de viagem - ensinar "o outro" desde a posição de autoridade de quem "já esteve ali” 328 se reproduz na prática do ensaio e dos escritos jornalísticos ${ }^{329}$. Assim, esses diferentes registros

${ }^{324}$ COLOMBI, Beatriz. Viaje Intelectual. Migraciones y desplazamientos en América Latina (1880-1915). Beatriz Viterbo Editora. Rosario, 2004. p. 18. Regina Crespo refere-se à escrita ensaística de Alfonso Reyes a respeito da Argentina como "diletantismo curioso". CRESPO, Regina, "Entre porteños y cariocas. Alfonso Reyes embajador" En: Catálogo Impreso de la exposición Alfonso Reyes. El sendero entre la vida y la ficción. Instituto Cervantes. Universidad Autónoma de Nuevo León. 2007. P. 82.

${ }^{325}$ Arciniegas não escreveu um diário ou memórias. Mas considero que a prática constante, quase cotidiana, da escrita "jornalística", fez às vezes destes registros. Nela constam todo tipo de impressões: leituras, lembranças, obituários, opiniões políticas, relatos de viagem, etc.

${ }^{326}$ Botrel, Jean François. "Cosmopolitismo e mediación cultural en la España del siglo XIX”. Península, Revista de Estudios Ibéricos. No. 4, 2007.

$327 \mathrm{O}$ jornalismo foi para Arciniegas um espaço de profissionalização como escritor: vinculou-se aos 19 anos a $E l$ Tiempo, onde foi redator, diretor da seção literária e diretor geral, e onde manteve um espaço até o final de sua vida, na década de 1990. Sobre o processo de vinculação aos jornais dos jovens estudantes da década de 1920, ARIAS TRUJILLO, Ricardo. Los leopardos. Uma história intelectual dos anos 20. Bogotá. Uniandes, 2013, que assinala que El Tiempo era o jornal que melhor pagava seus colaboradores e que Arciniegas era dos poucos que podia se manter sem receber esses pagamentos.

328 MOLLOY, Silvia, "Victoria viajera: crónica de un aprendizaje. En: OCAMPO, Victoria, La viajera y sus sombras. Crónica de u aprendizaje. Buenos Aires. Fondo de Cultura Económica. 2010. P. 10.

$329 \mathrm{O}$ ensaio e o jornalismo mantêm na região estreita relação, pois "muchos grandes ensayos tienen un origen periodístico", e aliás "comparten una finalidad principal: la divulgación, que contribuye al debate y movilidad de las ideas". Também o ensaio tem "una vocación de transmitir el saber" que o filia "a la didáctica, de la que sería una manifestación no formal y asistemática". OVIEDO, José Miguel, Breve historia del ensayo hispanoamericano. Madrid, Alianza Editorial, 1991, pp. 16-17. 
da escrita eram solidários mais do que divergentes ${ }^{330}$. A orientação pedagógica foi cara às práticas intelectuais de Arciniegas e à imagem de si que construiu como "estudante-maestro". Essa orientação implicou o exercício da mediação cultural, que realizou como escritor e político.

Nas páginas a seguir serão abordadas as impressões do escritor a respeito de Buenos Aires e sua relação com o restante do país e o entorno rural, assim como da cultura e da cotidianidade portenha. Nelas, o escritor ofereceu uma versão otimista, embora socialmente restrita da vida e da cultura bonaerense.

"La Calle Rivadavia”: a integração nacional e seus limites.

O primeiro artigo de Arciniegas dedicado a Buenos Aires apareceu em 23 de setembro de 1940. Arciniegas refletiu aqui sobre a integração do país e o papel de Buenos Aires no processo. O texto começa em tom hiperbólico: "Parece comprobado que la calle Rivadavia es la más grande del mundo”. Arciniegas ressalta em Diario de un peatón. La calle Rivadavia a centralidade dessa rua, que parte do "corazón de la ciudad”, e seu caráter metropolitano que constitui a imagem da modernidade urbana, “compacta, cerrada de tiendas, teatros y grandes edificios”. O sentido da rua, que avança para o interior do país, acompanha o triunfante passo da civilização sobre o campo aberto:

"Y llega a la pampa y por la pampa avanza. Y atraviesa estancias, ensarta poblaciones, y echa adelante como si buscara un montículo, una muralla o algo que pudiera detenerla. Pero siendo la pampa lisa y llana, la calle Rivadavia es infinita"

Arciniegas é entusiasta dessa articulação dos pampas pela rua que nasce na cidade, do fio que vai ligando povoados. A ordem do país e o seu sentido de unidade é representado nessa rua que se orienta infinitamente desde a capital. "Para la provincia de Buenos Aires, la Calle Rivadavia es como para los geógrafos el meridiano de Greenwich”. Rivadavia expressa também as mudanças na relação entre a cidade e a província. Tempos atrás a orientação foi ao contrário, a rua era canal de penetração da vida rural na cidade. Segundo escreveu Manuel Gálvez en La Vida de Hipólito

\footnotetext{
${ }^{330}$ Sergio Miceli tem colocado ênfase neste ponto, mostrando como no Brasil e na Argentina os escritores da década de 1920 separavam ou davam continuidade, respectivamente, às escritas jornalísticas nas produções literárias. MICELI, Sergio. Vanguardas em retrocesso. São Paulo. Companhia das Letras. 2013.
} 
Yrigoyen, citado aqui por Arciniegas, a Rivadavia era "esta raya de asfalto y adoquín que hace cien años era de polvo o lodo”, "era más un camino que una calle. Y más un avance de la pampa que una prolongación de la ciudad”. Arciniegas reforçava a imagem de Gálvez com sua leitura do processo:

"Hace cien años, la Argentina era más rural que urbana. Hoy, con Buenos Aires, es más urbana que rural. Hace cien años, aquí todos eran campesinos. Hoy, ciudadanos. Y la Calle Rivadavia ya no es más el avance de la pampa, sino la prolongación de la ciudad" ${ }^{\prime 31}$.

A seguir, Arciniegas extrapolou a experiência argentina para o resto do continente, colocando ênfase na juventude das cidades americanas. Essa extensão das reflexões sobre um país para o conjunto americano é um traço recorrente do método do ensaísta. Arciniegas afirmava que “Buenos Aires, como todas las ciudades de América, se ha hecho en este siglo”. Uma sensação de novidade que contrastava com suas impressões das cidades inglesas, onde passou também dois anos como funcionário diplomático, entre 1930 e $1932^{332}$.

Buenos Aires era uma cidade jovem, como as outras da América, que havia conseguido estender sua influência sobre o campo no interior do país para articulá-lo e construir uma ordem nacional. Símbolo da construção da unidade e da integração, a "calle Rivadavia" era o eixo do tecido nacional e simbolizava ao mesmo tempo a cidade moderna, de onde partia. Mas o escritor colombiano atentava à outra função nessa rua, aparentemente contraditória com a dimensão integradora já assinalada. Rivadavia era também fronteira no interior da cidade:

"Pero dentro de lo que es estrictamente la ciudad, dentro de los límites de la "Capital Federal", tiene, además, otra función. Buenos Aires, si no es dos ciudades, es cuando menos una ciudad partida por la Calle Rivadavia. Lo que queda a la diestra de Rivadavia es lo elegante, lo remozado, lo fino: a la siniestra está lo popular, lo tumultuario, lo del común. Si a vuelo de pájaro pudiera tomarse una fotografía espiritual de Buenos Aires, la ciudad parecería un traje de dominó: blanca toda blanca, a la diestra de la raya; negra, toda negra, a la siniestra/Desde luego, lo mismo pasa en Londres o Nueva York, donde una cosa es el "East Side" y otra el "West Side". O donde "Up Town" y "Down Town" son como el anverso y el reverso de la medalla. Pero en Buenos Aires, lo particular está en la precisión de la marca"

Vale notar a comparação com o espaço anglo-saxão que havia conhecido nos anos anteriores, antes de viver em qualquer outro país da América. Viajou para New York, onde permaneceu por

\footnotetext{
${ }^{331}$ Em Buenos Aires tiene cuarenta años (21/09/1941), reduziu o marco temporal deste processo, acentuando a rapidez da transformação. Buenos Aires "Hasta 1900 fue una pequeña ciudad. De entonces para atrás los potreros se metían por la calles. Por la de Rivadavia en tiempo de Rosas, entraban las carretas que venían de la campaña tiradas por yuntas de bueyes".

${ }^{332}$ Dez anos atrás Arciniegas havia transmitido uma imagem oposta em relação à Londres em Inglaterra país de segunda mano. Londres es una tienda de antigüedades (16/08/1931).
} 
uma breve temporada, em 1930, e depois passou dois anos na Inglaterra, até 1932. Em 1938, novamente viajou aos Estados Unidos, desta vez para São Francisco, onde permaneceu por oito meses antes da sua chegada a Buenos Aires ${ }^{333}$. A recorrência da comparação com essas cidades reforçava o argumento de autoridade do viajante para apresentar, opinar e descobrir as singularidades da Argentina. Nesse sentido, os escritos de viagem de Arciniegas se aproximavam ao ensaio, gênero no qual o autor é ao mesmo tempo o protagonista, ainda que apenas como observador ou intérprete da realidade.

Por outro lado, a ideia das cidades cindidas já havia sido explorada pelo autor em outros escritos, embora a divisão da cidade não aparecesse sob o mesmo sentido. Em Diario de um peatón (1936), Arciniegas havia publicado algumas notas sobre Medellín, muito semelhantes às escritas sobre Buenos Aires. Nelas descrevia uma cidadezinha fraturada pelo rio Medellín, marca nítida de separação entre a "cidade nova" e a "cidade velha", separação sublinhada pela existência de uma catedral de cada lado ${ }^{334}$. O que mostra que Arciniegas traduzia Buenos Aires baldeando suas características em imagens próprias da sua ensaística, mediando o relato da cidade pelo próprio universo criativo.

É notável a ambiguidade da integração nacional advertida pelo colombiano. E aqui é importante reconhecer o diálogo com a ensaística local. A rua Rivadavia é metáfora para o problema da relação entre Buenos Aires e o interior do país, um dos dilemas principais da ensaística argentina do século XX. Para Arciniegas, como dito, a organização do país realizada por Buenos Aires parecia um processo acabado e consumado no começo do século $\mathrm{XX}$, sem contestação histórica nem crítica dele próprio. O escritor construiu a imagem sem levar em conta as denúncias sobre os malefícios do crescimento de Buenos Aires, aparecida já no final do século XIX e vigorada na década de $1930^{335}$. Isolamento, materialismo, europeísmo, fratura ou artificialidade não foram reprovações de Arciniegas para a cidade. Pelo contrário, o colombiano celebrou na imagem da

${ }^{333}$ Destas viagens deixou alguns artigos no jornal. Planejou ainda publicá-los num volume titulado La isla de los caballos, mas o livro não apareceu. Alguns dos artigos são inclusos em Diario de un peatón (1936).

334 “La Catedral Vieja"; "La Catedral Nueva"; "Topografía de Medellín”, en Diario de un Peatón, Bogotá, Imprenta Nacional, 1936.

335 GORELIK, Adrián, A Buenos Aires...Op. Cit,p. 39. 
Rivadavia a expansão da estrutura rodoviária dos anos 1930, como sansão da formação do espaço nacional.

A integração em questão não refletia tampouco a ideia de uma Buenos Aires invadida pelos pampas, dos tempos de Rosas, de Sarmiento, ou, até de 1900, como disse Arciniegas em Buenos Aires tiene cuarenta años. Era uma alternativa à versão otimista da vanguarda dos anos 1920, que via Buenos Aires como a "encarnação mais plena dos pampas", a "capital dos pampas", como festejada por Borges nos anos 1920 e Raúl Scalabrini Ortíz, por exemplo, em $1931^{336}$. Rivadavia era, para Arciniegas, símbolo da integração e da mudança na direção da relação cidade-campo, a favor do mundo urbano.

Mas a Rua era - como a ferrovia no caso de outro ensaísta dos anos quarenta, Ezequiel Martínez Estrada -, metáfora que permitia articular a reflexão sobre a cidade e o país com a atenção aos problemas internos, urbanos. Para cada caso, o autor atribuiu à Rua valores opostos. No espaço urbano a rua não articula, mas divide, segrega ${ }^{337}$. E aqui Arciniegas reproduz uma imagem cindida da cidade que a própria toponímia bonaerense indicava, mas que ecoava uma representação de Buenos Aires que havia sido forjada em uma célebre polêmica entre grupos de escritores e artistas dos anos 1920, nucleados ao redor da dicotomia Boedo/Florida ${ }^{338}$. Segundo Adrián Gorelik, essa representação "geográfico-cultural” da cidade carregava já em 1940 certo anacronismo: Uma nova periferia urbana teria aparecido nos anos anteriores como resultado de uma onda imigratória, que desta vez não era europeia, mas interna e que redefiniu o sentido da fronteira na cidade, do norte-sul para o leste-oeste ${ }^{339}$. Ainda assim é interessante que Arciniegas observe a existência de uma divisão na Argentina, não entre a cidade e o campo, mas no interior da própria Buenos Aires.

O que importa salientar finalmente é que a divisão entre a "cidade branca" e a "cidade negra", na Buenos Aires de Arciniegas, anunciava um conflito que o escritor não explorou nesse artigo e em

${ }^{336}$ GORELIK, Adrián, "Buenos Aires y el país: figuraciones de una fractura" En: ALTAMIRANO, Carlos (ed.). Argentina en el siglo XX. Buenos Aires, Ariel, 1999, pp, 136-161. O autor salienta que o fracasso dos projetos integracionistas elogiados por Arciniegas foi advertido também por observadores estrangeiros, como o norteamericano Archibald McLeish.

${ }^{337}$ Em Martínez Estrada a ferrovia representa a exploração do interior por Buenos Aires e o capital estrangeiro e a lentidão do transporte urbano superado pelos ônibus. GORELIK, Adrián, La Buenos Aires...Op. Cit.

${ }^{338}$ SARLO, Beatriz. Una modernidad periférica. Buenos Aires 1920-1930. Buenos Aires. Nueva Visión, 1988.

${ }^{339}$ GORELIK, Adrián, La Buenos Aires...Op. Cit. 49-51. 
nenhum outro. Embora em seus escritos desses anos pode se encontrar vários trechos em que estas duas cidades entram em contato, ainda que a maioria deles se ocupe dos espaços e personagens da "cidade branca", que recebeu a admiração e o carinho do escritor colombiano.

As telhas e a questão da tradição

O espetáculo urbano de Buenos Aires não foi festejado acriticamente por Arciniegas, que se ressentiu da expansão dos arranha-céus e do deslocamento, que chegava até a virtual ausência das marcas hispânico-coloniais da cidade. O escritor via nesse fato muito mais do que um processo de urbanização. A centralidade deste contraste o fez dar ênfase ao caráter hispânico da identidade cultural de seu próprio país e da sua natalícia Bogotá. Lírico e nostálgico, Arciniegas escreveu em Buenos Aires, las tejas y los gatos (06/09/1941):

"La impresión que, para nosotros, dejan todos los edificios de Buenos Aires, es la de haberse quedado en la mitad del camino. No terminan. Son torres truncas. Les falta ese coronamiento natural de los tejados, sin el cual los bogotanos, por ejemplo, no concebimos que pueda hacerse una casa. Buenos Aires, a vuelo de pájaro, produce el efecto de una llanura de cemento. Como si un huracán hubiera hecho volar las tejas, y dejado a los hogares sin abrigo".

"Cuando miro las torres chatas de Buenos Aires, la superficie sin término de sus casas de azotea, se me enardece el amor por las tejas que anduve, de medias, por la juventud.".

Povoada de prédios altos, Buenos Aires representava uma civilização truncada, sem coroamento. A modernização era um furacão temível que fazia voar os telhados e deixava os lares desamparados, sem abrigo. Como outros escritores hispano-americanos que visitaram a Argentina na primeira metade do século XX, Arciniegas sentiu falta em Buenos Aires de um passado histórico importante, que não pode perceber.

Nos anos 1920 a ideia da Argentina como um país jovem havia sido cristalizada e em boa medida autorizada pelo filósofo espanhol José Ortega e Gasset. Uma versão anterior da comparação da Argentina com outros países latino-americanos, relativa à profundidade da história das outras nações, foi formulada por Alfonso Reyes nessa mesma década. Mas, para indicar o assunto, Arciniegas mobilizou a imagem, já central em sua ensaística, dos telhados. Com efeito, em América, Tierra firme $(1937)^{340}$, Arciniegas havia publicado um dos seus ensaios mais afamados

${ }^{340}$ América, tierra firme. Santiago de Chile. Ediciones Ercilla. 1937. p. 257-278 
- El lenguaje de las tejas - no qual consta uma reflexão sobre o sentido cultural de três períodos da história da Colômbia. Os telhados de palma, barro e zinco representavam respectivamente a experiência pré-hispânica, colonial e oitocentista, essa última sob influência britânica.

"Siempre que viajo en avión encuentro que no hay nada que me hable tan claro sobre los ciclos históricos como el techo de las casas. Nos ha tocado a los americanos vivir en el campo de experiencias sociales más rico que pueda imaginarse, y por eso podemos ver de un solo golpe techos grises de paja, tejados de barro cocido y casitas de teja metálica, que representan los tres tipos de cultura que se han turnado cronológicamente en el país" ${ }^{341}$.

Depois afirma, "Cuando el avión rueda sobre los paisajes de mi patria, veo, como ya lo he dicho, las tres etapas de la historia nacional" 342 . Como assinalado por Juan Gustavo Cobo Borda, “Arciniegas tuvo la virtud de sintetizar (...) algunas ideas elementales pero sugestivas sobre lo que América era, había sido y debía ser" ${ }^{343}$.

Arciniegas reclamava mais do que formas arquitetônicas, ressentia algo mais do que as frias construções, pois essas eram antes formas culturais e sinais de experiências históricas. Nesse sentido, a aparência da cidade desta vez não refletia a temporalidade compartilhada pelo resto da América hispânica e, além disso, estava carente dos traços de sua autenticidade como cultura.

"Nosotros, lo repito, no entendemos esto. Nuestra casa, de teja, la casa vieja que nos despedía en la mañana, cuando íbamos a la escuela, con sus aleros; la que trajeron los españoles en la colonia, sigue siendo la única casa auténtica (...)Las tejas han sido para nosotros algo así como el nacimiento de Cristo para la cronología"

Arciniegas adjudica à experiência colonial o sentido de autenticidade e de começo da história e parece considerar que a Argentina não se reconhece mais nela. Buenos Aires exclui não só um tipo de paisagem urbana, mas toda uma tradição cultural com suas formas de vida. $\mathrm{O}$ escritor completa a imagem dos telhados com um inesperado habitante deles, o gato, que exemplifica justamente a exclusão dessas outras formas de habitar o espaço e se comportar no mundo, como o Arciniegas criança andando de meias sobre os telhados. Os gatos de Buenos Aires foram deslocados para os bairros da periferia da cidade,

"Una de las cosas que más me intrigaban de Buenos Aires era la ausencia de gatos. Perro, si: mucho perro; pero gatos, nada. Mirando a la ciudad desde un balcón lo he comprendido todo. El gato no puede vivir sin los tejados. No tiene cómo dar sus paseos nocturnos, que son el ambiente de su vida, su esparcimiento, su experiencia de roce social En Belgrano, un barrio residencial alejado del centro de

\footnotetext{
341 Ibíd. p. 257.

342 Ibíd. p. 275.

${ }^{343}$ COBO BORDA, Juan Gustavo. Germán Arciniegas...Op. Cit. p. 133.
} 
Buenos Aires, vi los últimos cuatro gatos que recuerde en esta ciudad (...) Y ¿Por qué en Belgrano? Porque en Belgrano quedan también los últimos cuatro tejados de Buenos Aires. Lo demás, azoteas, llanura de cemento..."

Na defesa da arquitetura de origem hispânica, da experiência cultural que essa representa e das formas de vida que favorece e acolhe, Arciniegas parece muito próximo das posições adotadas na Argentina pelos representantes da chamada "geração do centenário" e pelos criollistas dos anos vinte. Suas referências a Manuel Gálvez, já citadas, reforçam a ideia da afinidade com esses setores do mundo letrado portenho que lamentavam a perda de uma cidade, uma língua e uma cultura de matriz hispânica.

Arciniegas escreveu sobre Belgrano mais uma vez quando fez a crônica de sua visita ao escritor Enrique Larreta ${ }^{344}$. Ainda teve outra ocasião de trazer à tona os telhados, mas desta vez fora da cidade, quando de sua visita a Mar del Plata. O balneário era então espaço privilegiado para o lazer das classes altas e médias durante o verão. Arciniegas seguramente visitava a "quinta" de Victoria Ocampo, onde confluíam vários membros de seu círculo. Descrevendo as casas do local em Diario de un peatón. Mar del Plata (19/01/1941), Arciniegas apontou: “lo mejor en ellas, su bandera de color, está en los tejados, en los tejados bermejos, que ya nunca se ven en las ciudades, y que son como un recuerdo del mundo de colores que vienen destruyendo los adoradores del cemento"345. A seguir Arciniegas se dirigia diretamente aos seus leitores colombianos, advertindo-lhes sobre a importância de manter a tradição e avançar cautelosos, temendo o furacão e o redemoinho:

\footnotetext{
"Pensad, oh bogotanos!, por un instante, qué sería de vuestra ciudad si un día cualquiera soplara sobre ella el viento huracanado y la sacudiera como se sacude un árbol al final de otoño. Las tejas secas, doradas, volarían como hojas, arremolinándose sonoras en la distancia. Las casas destapadas, sin fronda, se verían todas. Se vería todo. Y allá en el remolino, remotos, entre las tejas, los gatos! Una visión dantesca"
}

Sem fazer referência direta aos imigrantes, que despertaram na geração argentina do Centenário e nas Vanguardas dos anos 1920 reprovações em relação à perda das tradições criollas -

${ }^{344}$ Cosas de América: Enrique Larreta 21/04/1940. Sobre a arquitetura do bairro também reparou um escritor alheio ao saudosismo criollista, em textos para jornais: Arlt, Roberto. Paisaje em las nubes. Crónicas en El Mundo, 19371942. Buenos Aires. FCE. 2009.

345 "Mar del Plata era considerada a princípios de la década del 40,como una ciudad con identidad propia, que había logrado no sólo evitar la copia de las imágenes metropolitanas, sino llegar a erigirse como su contracara". Isto pela "uniformização" das construções rústicas que tomaram fôlego com a importação do "modelo californiano" de turismo "basado en el uso del automóvil y en su arquitectura de matriz española", na década de 20. BALLENT, Anahí. "Mar del Plata: croquis en la arena". Em: ALTAMIRANO, Carlos (ed.) Argentina em el siglo XX...Op. Cit, pp, 201. 
semelhantes às do colombiano - como problema para a identidade nacional, Arciniegas fez um chamamento aos leitores colombianos para descobrir, conservar e valorizar a tradição, lar seguro de cultura, de "terra cozida", matéria para ser trazida à vida com imaginação. Imagem que sintetiza um projeto cultural ${ }^{346}$ :

"Claro: ya las tejas bogotanas han envejecido. Ya no son bermejas como el primer día. Cubiertas de líquenes, verdeazulean como las chamizas en el monte. Pero eso no importa. Nosotros sabemos que en su entraña está la tierra cocida. No hay sino que soplar un poco con la imaginación, y debajo de las cenizas se encontrarán las brasas"

A tradução que Arciniegas fez de Buenos Aires para seus leitores colombianos lhe permitiu reforçar as tomadas de posição perante a cultura nacional a propósito da tradição hispânica e o fez, de novo, com recursos de uma poética ensaística própria.

\section{Cenas democráticas}

Para Arciniegas, Buenos Aires, e a Argentina em geral, era uma sociedade democrática. Arciniegas percebeu e quis transmitir o espetáculo que encontrava curiosamente nos espaços de lazer da nascente classe média, fora âmbito marcado pela divisão entre a "cidade branca" e a "cidade negra", antes assinalada. Em Diario de un peatón. Domingo en El Tigre (11/02/1940), Arciniegas relatou seu passeio a este distrito de canais onde se ia "a ver morir la tarde" e particularmente ao restaurante Bocas del Toro, erigido numa das ilhas do delta. O escritor afirmou, acudindo de novo à comparação com o mundo anglo-saxão, que:

\footnotetext{
"Este canal es tan democrático como la Avenida de Mayo, como la Calle Corrientes, como cualquier arteria urbana de Buenos Aires. Qué alegre ruido el de las gasolinas y los botes remeros! Son cientos, miles, que se hacen nudos donde hay una vuelta del río, que se aprietan como los automóviles en una calle de Nueva York" 347
}

346 Arciniegas compartilhava a valorização do urbanismo e a arquitetura colonial hispano-americana com outros
escritores e artistas colombianos. Na Revista de las Indias, que ele dirigiu, foi costumeira a inclusão de fotografias
das construções mais emblemáticas do período, não só em Bogotá, mas também em Cartagena e Popayán. No
começo da década de 1930, Arciniegas construiu uma casa em estilo neo-colonial, com peças tiradas de demolições
no centro histórico da cidade. A casa, que ainda está em pé, está localizada no bairro Teusaquillo onde a elite da
cidade criou um novo espaço urbano com ruas diagonais e casas em estilos ecléticos, sob orientações do art-decó.
Arciniegas se opôs também às diagonais, defendendo a retícula tradicional.
347 Para Arciniegas "el automóvil es uno de los pasos más serios que se han dado en el camino de la democracia",
"lo maneja cualquiera", "los miopes, la mujeres, los impúberes, los boticarios, los albañiles, el viejo de barbas, la
gente de respeto, los plomeros y los anticuarios". Pelo contrario, o cabriolé puxado por cavalos e dirigida por um 
Com suas "lanchas colectivas, botes remeros, yates”, El Tigre acolhe a população de Buenos Aires que visita o labirinto de ilhas e canais, uma "Venecia de los bosques", uma "selva del Amazonas parcelada" em "islitas que puede comprar un hombre medianamente rico" - como por exemplo o poeta Oliverio Girondo. Girondo, que na verdade, longe de ser medianamente rico era representante das famílias mais tradicionais e abastadas do país, ao lado de Victoria Ocampo $^{348}$. Arciniegas se esforçava por transmitir aos colombianos a imagem de uma Argentina próspera onde a riqueza era distribuída naturalmente, por excesso, entre a população $0^{349}$.

Em Diario de un peatón. Mar del Plata (19/01/1941), Arcinegas descreve o espetáculo que oferece a migração dos “huéspedes del verano", que vêm de "Todo Buenos Aires, toda la Argentina” e "quieren asomarse a este balcón suyo, para ver el mar”. Refere-se à aparição desta “apretada masa de gentes que saludan al mar de enero". Por ter se antecipado à temporada de férias, Arciniegas pôde observar a localidade antes e depois da chegada dos turistas, notando a mudança no ambiente:

"Cuando vinimos en Navidad ya todo estaba reluciente y vacio. Los criados, con la servilleta al brazo esperaban tranquilos en el comedor desierto. Hoy una población flotante invade las calles, se apretuja en los hoteles y en la playa no se sabe qué hay más: si granos de arena o personas.".

A pesar de valorizar espaços como as ruas e os canais de convivência no trânsito, Arciniegas não pôde evitar se sentir invadido pelas massas no balneário, pois a multidão exclui a sobriedade e a elegância dos hotéis e os restaurantes vazios: "Todo deja una impresión constante de desbordamiento, de invasión, de negra espuma que la marea de la tierra arroja sobre el hervor blanquísimo del mar”.

A impressão de invasão que teve Arciniegas em Mar del Plata era resultado do sucesso da expansão do turismo ${ }^{350}$ na cidade, que havia começado nos anos 1910 visando construir "un ámbito de sociabilidad entre pares, en el cual las caras nuevas, (...) no eran bien recibidas", mas

“auriga", "tiene lo escencial de la vida cortesana". Arciniegas, Germán, "Aurigas y choferes", Em: Diario de un peatón...Op. Cit., pp, 23-26.

${ }^{348}$ Sobre a origen social e o sentido da trajetória de Girondo e outros escritores da sua geração, Miceli, Sergio, Vanguandas em retrocesso. São Paulo, Companhia das Letras, 2012.

${ }^{349}$ Regina Crespo sublinhou duas tendências no relato de viagem dos escritores mexicanos que visitaram o Brasil nestas décadas: a visão utópica, representada por José Vasconcelos, e a crítica, encarnada por Alfonso Reyes, quem não exclui o conflito em suas leituras do país. CRESPO, Regina, "Cultura e política: José Vasconcelos e Alfonso Reyes no Brasil (1922-1938) En: Revista Brasileira de História, V 23, No. 45, pp. 187-208. 2003.

${ }^{350}$ Arciniegas visitou também o segundo espaço privilegiado do turismo em automóvel destes anos, Cacheuta, perto de Mendoza. Ver: Diario de um peatón: las piedras de Cacheuta 03/03/1941. 
que recebeu na década de trinta um estímulo oficial que fez do balneário "el escenario que construyó la Argentina para ver el mar como espectáculo", com grandes construções para o turismo massivo como o próprio Hotel Bristol. Como diz Anahí Ballent, a discussão era "si tal belleza merece ser contemplada cuando la ciudad está "vacía" o cuando la ciudad se encuentra "llena”, si su belleza exige un consumo individual o colectivo" 351 . Arciniegas foi sensível ao luxo de hotéis, barcos e restaurantes que retratou em vários artigos sobre Buenos Aires e dos quais era tacitamente excluída a multidão que invadia os balneários "como negra espuma”. $\mathrm{Na}$ amplitude dos restaurantes vazios, Arciniegas se sentia à vontade, quando todo é "reluciente y vacío", como "En el comedor del Hotel Bristol, suntuoso y resplandeciente” onde, ambíguo, diz que "hay millares de personas que se mueven con holgura".

\section{Os criados, as calças, o sotaque: ordem, riqueza, disciplina.}

Germán Arciniegas deixou-se seduzir pela riqueza que se ostentava em certos círculos portenhos, pela elegância experimentada em seu cotidiano e pela disciplina que em tese explicava a riqueza e a elegância. Em várias ocasiões nas quais descreveu jantares e almoços em hotéis, barcos e restaurantes, Arciniegas pôde ver essas qualidades no comportamento dos habitantes da "cidade branca". Além do Hotel Bristol de Mar del Plata e do restaurante Bocas del Toro em El Tigre, Arciniegas fez digressões sobre estes espaços em suas notas sobre os serventes, o tango e o sotaque dos portenhos.

Em Buenos Aires tiene cuarenta años (21/09/1941), Arciniegas já havia afirmado que "Hoy, una de las cosas más impresionantes que tiene Buenos Aires son los criados" e advertia que esses "Deberían ser minuciosamente retratados porque pronto sus imponentes efigies constituirán documentos imposibles de reconstruir". Mas os criados não eram o que sobrou de um passado cortês e sim parte do presente burguês da jovem Buenos Aires. Arciniegas surpreendeu-se com o influxo civilizatório que a prosperidade do país trouxe às suas gentes em pouco tempo e em especial aos serventes, mas também anunciava sua desaparição como se eles não pudessem existir no século XX:

${ }^{351}$ BALLENT, Anahí, “Mar del Plata...” Op. Cit, pp. 194-195. 
"Usted puede llegar a un palacio y sobreponerse un tanto al ambiente de suntuosidad que imprimen las lámparas, los bronces...pero se verá siempre como un microbio a los pies de un criado. Criados de librea, de uno ochenta, de uno noventa, de dos metros, que parecen estar en su puesto desde que el rey Luis XIV de Francia era un niño. $Y$, en realidad, estos criados no tienen sino cuarenta años. ¿Y cómo - preguntará usted - eran los criados del siglo XIX?"

Arciniegas respondeu à sua própria pergunta citando um jornal de começo do século XIX, onde se anuncia: "se vende un criado joven”, “que es propio para el campo y la ciudad”, e revela aos leitores que o trânsito da rusticidade ao refinamento é o da escravidão ao trabalho livre ${ }^{352}$. Arciniegas construía a imagem de uma sociedade livre, democrática e prospera, sem os lastres de um passado cortesão, mas onde eram corretamente encenadas as hierarquias.

A elegância e a gravidade dos portenhos são indicadas por Arciniegas ainda com maior clareza em comentário sobre o tango. Em Diario de un peatón. El Tango es algo serio (31/01/1940), Arciniegas se localiza de novo nos espaços de sociabilidade das classes altas. Arciniegas leva o leitor até ali: "Está usted en el comedor de un gran hotel, en un restaurante, en la cubierta de un barco. La orquesta desata toda esa música que universalmente se usa para que la gente haga acrobacia rítmica y se divierta". Quando soa o tango toda a diversão é detida e a elegância entra em cena:

"En efecto, empieza el tango y se ve que la línea del pantalón cae mejor, que el saco que estaba arrugado como acordeón cuelga de los hombros del bailador lo mismo que si estuviera en la percha del sastre, el cabello se sienta, y se acabó la charla. Ya nadie vuelve a decir palabra".

Paradoxalmente, a ordem aparece quando soa o tango. A roupa, o cabelo e a boca adotam posturas serias que refletem a disciplina da dança, e não a diversão, que é excluída - "O se baila el tango, o se va a divertirse, pero las dos cosas no pueden hacerse al mismo tiempo”. É notável que Arciniegas não mencione a origem popular do tango e que tenha contato com ele em espaços próprios das classes privilegiadas, deslocando seu significado histórico ao simples gesto imposto, que exige concentração e que mais do que a vida dos trabalhadores do porto, a vida nos bairros populares ou a nostalgia dos imigrantes, tem a ver com o rigor e a riqueza da sociedade $\operatorname{argentina}^{353}$.

Todavia, Arciniegas pretendia revalorizar o tango perante algumas leituras a propósito de sua relação com a identidade nacional argentina. "Época hubo en que Europa miró a la Argentina a

\footnotetext{
${ }^{352}$ Arciniegas volta aos criados e aos barcos em, Un mundo a bordo: El que no pudo ver a Evita Perón (30/08/1947).

353 Garramuño, Florencia, Modernidades primitivas. Tango, samba y nación, Buenos Aires, Fondo de Cultura Económica, 2007.
} 
través del tango. Se creía que la Argentina no era más que un paso de baile”, afirmava, e que como reação muitos argentinos o depreciavam e o tinham como coisa de pouco valor cultural e pouco séria. Mas o país revelou-se como um centro cultural de primeira ordem, sua economia prosperava: "La Argentina no es el tango - se dijo; - la Argentina es algo muy serio". Arciniegas encontrava o significado do tango precisamente na seriedade do gesto, manifestação dessa riqueza.

Sem se referir ao tango em suas Palabras sobre la nación argentina (1929), o mexicano Alfonso Reyes havia colocado a ênfase também sobre a disciplina ${ }^{354}$ que flutuava no ambiente do país e, como Arciniegas, havia mencionado a linha das calças como símbolo dela ${ }^{355}$. Malgrado, para Reyes a função da disciplina revelaria, por um lado, o voluntarismo político atrás da construção de uma nação sem tradições e, por outro lado, o rigor para manter a ordem social no meio de tensões fundamentais entre "patrícios" nativos e "plebeus" imigrantes, como na Roma da antiguidade $^{356}$. Para Arciniegas, pelo contrário, disciplina e elegância eram resultado de um clima de concórdia básica e prosperidade ${ }^{357}$.

O historiador argentino Jorge Myers chamou a atenção sobre a importância das viagens para a formação das imagens do ensaísmo de Reyes, advertindo nele "a vontade de criar imagens sintéticas que servissem para condensar toda uma interpretação altamente complexa da cultura nacional observada (..) e sua relação com a América Latina”. Esta observação poderia se estender ao caso de Arciniegas, pois como afirma Myers:

\footnotetext{
${ }^{354}$ Para o historiador José Luis Romero, o período entre 1930 e 1943, além de um brilho cultural, foi atravessado por "certo sentimento aristocratizante (...) manifestado em uma sostenida preocupación por la elegância que acentuo el tradicional empaque del porteño y de la porteña". Romero, José Luis; Romero, Luis Alberto. Buenos Aires. Historia de cuatro siglos. Desde la ciudad burguesa hasta la ciudad de masas. Buenos Aires, Abril, 1983, p. 201. Citado em Meo Laos, Verónica. Vanguardia y renovación. Asociación Amigos del Arte (1924-1942). Buenos Aires, CICCUS, 2006 , p. 114.

355 Sobre as afinidades entre as imagens da América e a escrita ensaística de Reyes e Arciniegas, dois pequenos e sugestivos artigos de Willis Robb, James, "Imágenes de América en Alfonso Reyes y en Germán Arciniegas", Humanitas, Monterrey, 1964, págs. 255-269; y "Variedades del ensayismo en Alfonso Reyes y Germán Arciniegas" Thesaurus. Tomo XXXVI. Bogotá. 1981. Do mesmo autor "Alfonso Reyes y Germán Arciniegas: corresponsales e hispanoamericanistas afines". Thesaurus. Tomo XXXVIII. Bogotá, 1983.

${ }^{356}$ Reyes, Alfonso, "Palabras sobre la nación argentina". En: Obras Completas de Alfonso Reyes IX, Fondo de Cultura Económica, México, 1981, p. 28-41.

357 Segundo Regina Crespo, "a pesar del tono un tanto agrio" de sus Palabras sobre la nación argentina, "El mexicano había perdonado a Buenos Aires su corta historia y la casi inexistente presencia del pasado, y lo hizo debido quizás al glamour europeizante y a la intensidad de la vida cultural que la ciudad le propiciaba". Crespo, Regina, "Entre porteños y cariocas. Alfonso Reyes embajador" En: Catálogo Impreso de la exposición Alfonso Reyes. El sendero entre la vida y la ficción. Instituto Cervantes. Universidad Autónoma de Nuevo León. 2007. P. 87.
} 
"Essa vontade de plasmar em "figurações" a interpretação da realidade cultural do continente latinoamericano seria o eixo em torno do qual se articularia o projeto da história cultural, promovido quinze anos mais tarde por toda essa falange de escritores integrados ao circuito lábil e permanente de intercâmbios que o sistema epistolar do diplomata mexicano soube ser, permitiu-lhe aprofundar e refinar sua visão da cultura latino-americana [...]." ${ }^{358}$.

Voltando às ideias de Arciniegas sobre a Argentina como uma sociedade disciplinada, democrática e próspera, o escritor colombiano opinou que o sotaque dos $\operatorname{argentinos}^{359}$ era manifestação desse estado de ânimo alheio aos conflitos e aos esforços. Em Diario de un peatón. No son esdrújulos. Sobre el acento de los argentinos (03/04/1940), Arciniegas sustentou que, entre vários sotaques "disponíveis" na Espanha do século XV, os argentinos teriam "escolhido" este por se ajustar à vida do país, caracterizada pela amplitude, abertura e riqueza do solo ${ }^{360}$. Aqui mais uma vez o contraste com os Estados Unidos:

"Porque la vida tiene acá ese acento. El argentino no tiene el ímpetu de los norteamericanos, que esdrujulizan la vida viviéndola a saltos, sin tregua y sin reposo. El argentino deja caer el acento final como si tirara definitivamente la palabra sobre un diván"

O sotaque dos argentinos é quase descanso, retiro, relaxamento e economia gestual.

"Esta última sílaba el argentino - el porteño - la alarga, la coloca entre un poco de música, le da una cadencia en donde los profanos vemos la raíz del tango. En esa música se ahoga lo que está de más, lo excesivo, lo inútil (...) Donde nosotros movemos la cabeza hasta alborotar el cabello, el argentino pone apenas una arruga en la frente. No la arruga honda y vigorosa, sino la que hace una brisa suave sobre un lago dormido"

$\mathrm{O}$ argentino é tranquilo como um lago. Seu sotaque "retrata el punto final. Y lo hace apagando la voz, con el dejo de quien se retira, corta la luz y bosteza”, "En la vida ordinaria sorprende el modo como se extingue la mímica en una conversación. El hombre que termina una frase se relaja en la silla, deja caer la mano, entorna los ojos".

\footnotetext{
${ }^{358}$ Myers, Jorge, Gênese "ateneísta" da história cultural latino-americana. Em: Tempo social. Revista de sociologia da USP, 17. São Paulo. 2005, p. 46.

${ }^{359}$ Arciniegas não diferencia o sotaque dos portenhos dos sotaques de outras regiões da Argentina.

${ }^{360}$ Arciniegas começava o artigo que se vem comentando tomando posição no debate sobre a origem ibérica da variação dialetal argentina que animava aos filólogos e escritores do momento. Apoiava a tese da origem andaluza, defendida também por Pedro Henrríquez Ureña. Ver Myers, Jorge, Gênese "ateneísta" da história cultural latinoamericana. Em: Tempo social. Revista de sociologia da USP, 17. São Paulo. 2005, p. 17; Falcón, Alejandrina. "Debates sobre las lenguas nacionales en la revista Sur (1931-1945), Fragmentos, número 37, Florianópolis, juliodezembro 2009, p. 181-201. Outro texto de Arciniegas sobre aspectos da linguagem argentina: Gacetilla de Buenos Aires. Cosas de la lengua española (06/07/1956).
} 
Segundo Arciniegas esse estado de ânimo não contradiz a força da nação. "No quita este acento un vigor interno a la vida argentina. De otra suerte, sería inexplicable la grandeza de esta república, que es una grandeza auténtica”. Mas em sua opinião o território argentino não exigia grandes sacrifícios para ser aproveitado. Tampouco existia uma situação que levasse aos argentinos à luta. Parece que Arciniegas vivia na Argentina a utopia da prosperidade e da democracia:

"En Buenos Aires se sube al cuarto piso de una casa humilde por escaleras de mármol, y mármoles y bronces se dan como el árbol o el rosal en los jardines públicos y en los privados. La riqueza de las grandes familias se derrama en las fachadas y en gigantescas arañas de cristal (...) Todo el oro se ha movido por cauces anchos, naturales, y en la ciudad que es el delta revientan de la abundancia las cajas de ols (sic) bancos".

No espetáculo da riqueza no país "nada deja la impresión de una lucha titánica. Somos ricos, porque somos ricos, pueden decir los argentinos". Para finalizar o artigo, Arciniegas citou um trecho do famoso ensaio de Raúl Scalabrini Ortiz, El hombre que está solo y espera. O trecho acaba com a pergunta do Hombre de Corrientes y Esmeralda, "Y pa' qué deslomarme si mi suerte es reventar?”. Escreve Arciniegas: "Pa qué deslomarme? He aquí toda una interpretación de la vida porteña (...) Hay que eludir el salto brusco. El porteño lo ve desde lejos con fastidio”.

A referência final de Arciniegas a Scalabrini, lacônica, merece um pouco de atenção. As reflexões de Arciniegas pegaram carona nas ideias de Scalabrini sobre o modelo do homem argentino que teria aparecido entre 1890 e 1930 e que o autor argentino explicitamente generaliza como "arquétipo", “que sin pertenecer a nadie, está en todos alguna vez”. Scalabrini argumenta que a Argentina tem uma terra dócil e opulenta, uma "tierra invisible" que produz quase sozinha, que não sugere a luta contra a natureza, mas perante o próprio espírito e que amolece os sentidos. Seu produto são homens ociosos, taciturnos, sofridos, de poucas necessidades nem aspirações, que vivem sob "el despotismo del silencio y la quietud", o "espírito de la tierra”. O Homem de Scalabrini que ecoa na citação de Arciniegas desacredita do esforço individual. Jogado no meio da imensidão dos pampas e do céu descobre "su finitud humana en la magnitud del tiempo y el espacio" "361. Daí seu desprezo pelo afã de lucro, a rejeição à planificação, às fórmulas intelectuais,

${ }^{361}$ Scalabrini Ortiz, Raúl. El hombre que está solo y espera. Buenos Aires, Librerías Anaconda, 1933, p. 94. 
ao esforço de pensamento e também a frugalidade, a misantropia como a falta de paz interior e a tristeza expressada no tango ${ }^{362}$, que Arciniegas não viu.

Tampouco interessou aqui a Arciniegas fazer menção de outras ideias centrais no ensaio de Scalabrini que têm a ver com o processo de "digestão" e "trituração" dos imigrantes europeus pelo ambiente local e as transformações sofridas pelos homens e a vida portenha: o "recolhimento" da cidade, o isolamento e abandono de seus habitantes que não dispunham de teatro, bailes, cinema nem rio. Scalabrini se esforçou por assinalar o processo de assimilação dos imigrantes numa nova raça em formação - salientando a novidade que deixava atrás esses "intrusos que formaban hordas de la más péssima calaña" -, assunto que não importou ao colombiano neste pequeno texto. Seleções e apresentações que, no desfase, na parcialidade, indicam o papel do mediador e o sentido de sua atividade ${ }^{363}$ que atenta menos ao contexto argentino e mais ao público colombiano, pois no país do escritor o problema da imigração não atravessava os discursos nem os debates sobre a nacionalidade. Interessou sim a Arciniegas transmitir a interpretação "optimista e integradora de la sociedad", achada por Scalabrini no momento crítico que foi o começo da década de 1930, mas que não refletia o clima social experimentado nos bairros populares de Buenos Aires, de dificuldades e novas migrações, nem nos campos e cidades da Colômbia ${ }^{364}$.

\section{La Boca, força e latinidade.}

Germán Arciniegas escreveu apenas uma vez para seus leitores colombianos sobre os bairros populares de Buenos Aires, a "cidade negra", onde justamente moravam aqueles imigrantes, já velhos, e seus descendentes. A ocasião não foi uma curiosidade especial por esses setores da urbe, mas a visita à oficina do pintor Benito Quinquela Martin, então já afamado artista argentino. Benito Quinquela: el más fuerte y vigoroso pintor del puerto de Buenos Aires (26/05/1940), começa com a apresentação do pintor em relação com o entorno, a Boca.

\footnotetext{
362 Ibíd, p. 18.

363 Joyeux, Beatriz. "Les tranferts culturels. Un discours de la méthode. Hyphothèses. 2002/1. pp. 151.

364 Saítta, Sílvia. "Modos de pensar lo social. Ensayo y sociedade em la Argentina (1930-1965). Em: Neiburg, Federico; Plotkin, Mariano. Intelectuales y expertos. La constitución del conocimiento social en la Argentina. Buenos Aires, Paidós, 2004, pp. 107-146.
} 
Arciniegas quis salientar que sua arte, especialmente os murais e seu compromisso com a localidade e seus habitantes, obedeciam a uma atitude que o escritor considerava ser própria de um "artista moderno".

Em boa parte, as impressões de Arciniegas sobre o bairro e o porto estiveram mediadas pelo olhar do pintor. "Desde el estudio de Quinquela he visto el abigarrado espectáculo del puerto. El mismo pintor se ha encargado de mostrarme colores inverosímiles que trasladados al lienzo parecen invento de la fantasía”. Arciniegas se coloca perante o mundo do trabalho no porto numa posição "de fora" - a oficina do artista - e desde ali, pelas indicações que o pintor lhe faz, o escritor pôde ver o porto. Ainda mais, Arciniegas apresenta os trabalhadores, mas apenas descrevendo as peças de Quinquela!

"Ahi están los cargadores de carbón que llevan canastadas de piedra negra sobre los hombros robustos; los cosedores de velas; los pescadores que regresan arrastrando las redes enormes; las mujeres que levantan al aire sus hijos para que el padre que se hace a la mar alcance a ver el último adiós de la criatura"

Arciniegas fez algumas observações sobre o bairro. Explicou a localização da Boca na cidade e a recorrência dos alagamentos. Quando para, frente aos rostos dos moradores, descobre o lado de Buenos Aires que permanecia oculto à sua vista, descobre também a luta e com ela outra economia gestual:

"La vida en estos barrios es alegre y grotesca. En tan brava la lucha, así en el trabajo como en el placer, que la conducta de los hombres y hasta su rostro mismo se sale del reposado equilibrio que, al menos en la apariencia, atempera el tono y dibujo de otras clases sociales"

Se Arciniegas conseguiu a empatia com o cotidiano deste espaço da cidade, que lhe pareceu grotesco, mediante o filtro estetizante da obra do pintor, o porto também lhe seduz, embora não fosse por ele próprio. Arciniegas viajante atravessava não só espaços, mas também épocas, fazendo uso da imaginação histórica. Arciniegas pensou na Boca: "Así debía ser el viejo Amsterdam, así Cádiz cuando se hacía el descubrimiento de América, así Brujas en los tiempos de su apogeo comercial”.

Esse recurso era duplo. De um lado comparava Buenos Aires com outras cidades europeias, o que depois reafirmaria comparando-a com Madri, Paris, Génova etc. Por outro lado, este recurso à imaginação histórica lhe permitiu ver o passado para recriá-lo em seus livros mais históricos. E em outros relatos de viagem, na Europa, por exemplo, sempre se interessou por conhecer os 
lugares onde aconteceram episódios que marcaram a história da América ${ }^{365}$. Dessa maneira, Arciniegas podia construir um vínculo com espaços alheios e estranhos.

Quando Arciniegas regressou a Buenos Aires em finais da década de 50, visitou novamente o atelier de Quinquela. Desta segunda vez na Boca, deixou testemunho num artigo, Los Caballeros de la orden del tornillo (09/06/1957), e sua relação com o bairro, "el más pintoresco de Buenos Aires", "trocito de Marsella o Génova", foi muito mais empática. O bairro havia se transformado pelo trabalho social, as doações e as próprias obras de Quinquela sobre os muros das casas e o porto. Mas também o olhar de Arciniegas tinha mudado, com certeza, depois de escrever dois livros sobre a Renascença e um romance que começava precisamente num porto italiano, em meio à cultura popular. Para Arciniegas, então:

\footnotetext{
"Boca es un balcón abierto al más lindo recoveco de aguas en donde las barcas se apretujaban combinando colores de anilina, nombres en las proas de mujeres y de Santos, mástiles. Es una pintura viva en un museo del aire libre y de la gente humilde. Nada de academia. Pescado, mal español, mal italiano, mundo latino!"
}

A celebração era a da identidade cultural. Já Arciniegas não comparava a Boca com Amsterdã ou Bruges, mas com Gênova e Marselha. A mudança de opinião, interessante no próprio processo de Arciniegas, carecia, por outro lado, de vigência para os argentinos. A questão social no país do sul não passava mais pelo conflito cultural e linguístico como nas primeiras décadas do século. Os novos bárbaros, para apelar à imagem de Alfonso Reyes, eram os migrantes rurais chegados à cidade, dispostos a se articular de maneira tumultuosa no espaço público nacional ${ }^{366}$.

\section{$O$ rio e o ar de Buenos Aires.}

Arciniegas regressou à Argentina na década de 1950 - já radicado nos Estados Unidos, onde permaneceu até 1958 - no marco de uma série de conferências que o levou a vários países do continente denunciando os governos militares que apareceram na região, a começar pelo

\footnotetext{
${ }^{365}$ Quando na década de 1950 Arciniegas viajou em várias ocasiões à Itália e França, visitou lugares nos quais percebeu o rastro da história da América (embora não ser relato de viagem, o nome de um livro posterior, América en Europa, expressa justamente o sentido dessa experiência), fazendo com que sua viagem à Europa fosse uma viagem ao passado na qual descobria o sentido da experiência histórica americana.

${ }^{366}$ Sobre a atenção que recebeu essa população nas interpretações da nacionalidade argentina a partir da queda de Perón: Saítta, Sílvia, "Ensayo y sociedad..." Op. Cit.; Neiburg, Federico, Los intelectuales y la invención del peronismo. Estudios de antropología social y cultural. Buenos Aires, Alianza, 1998.
} 
peronismo e o governo militar colombiano encabeçado pelo general Gustavo Rojas. Essas viagens lhe permitiram criar séries de artigos para o jornal, descrevendo paisagens e situações de quase todos os países da América, do Canadá até a Argentina e o Chile. Um destes conjuntos de artigos levava o titulo de Cuadernos de Geografía, o outro Viaje por América ${ }^{367}$. A integridade das séries poderia merecer um estudo de conjunto, mas aqui vamos nos referir apenas aos artigos dedicados à Argentina.

Parte dos Cuadernos de Geografía, "Los tres países del plata” (06/03/1950), é uma extensa nota sobre a geografia de uma área muito ampla, que supera os marcos nacionais, abrangendo do Paraguai até a Terra do Fogo e dos Andes ao Atlântico, mas acaba por se concentrar no território argentino. O texto tem uma interessante reflexão sobre a relação entre Buenos Aires, a selva, o rio e o Polo Sul.

Segundo Arciniegas a cidade vivia uma ameaça constante de alagamento, que então já se anunciava como a negação da cidade que é essencialmente uma forma de vida transplantada, fora de lugar, erigida de costas ao marco natural que a acolhe. Quando tem enchente "Entonces las calles bajas de Buenos Aires se inundan y hay un olor de selva en la ciudad", "Cuando viene creciente del norte en la llanura líquida del estuario flotan gajos de árboles: mensaje de un lejano mundo vegetal”. Este é o influxo do norte, da selva, mas existe outro que vem do sul e neutraliza o efeito hostil do norte selvagem:

“Sobre Buenos Aires soplan dos vientos. El que viene del norte es embrujado, húmedo, cálido. Nace en la rosa verde que está sobre el corazón de la América del Sur. El habitante del puerto, que es europeo, cuando llega este viento, siente que algo le aprieta en las sienes y le afloja la voluntad. El viento austral, en cambio, que nace de la flor del Polo y corre sobre el desierto seco, disipa estos embrujos: entonces los tres millones de habitantes que están en torno a Buenos Aires encuentran más blanca y más azul la bandera celeste de la república”

A nação argentina, representada na bandeira "branca e celeste da república" é então o triunfo do vento do sul e da vida transatlântica transplantada - transparência e claridade envolvendo o Pólo Sul, o deserto seco e a bandeira - sobre o vento escuro do norte verde e o anúncio da floresta que traz o rio quando há enchente. Arciniegas reproduz e celebra essa imagem de Buenos Aires,

\footnotetext{
${ }^{367}$ Viaje por América. Reencuentro con Buenos Aires (28/06/1956), Viaje por América. Reencuentro con la Provincia (03/07/1956), y Desde Buenos Aires. Ambiente de altiplano (05/06/57).
} 
cidade cosmopolita, que apenas dá espaço às expressões da alta cultura e da sociabilidade da elite. "Cidade branca":

\begin{abstract}
"Buenos Aires es de las más hermosas del mundo. Le Corbusier trazó sus nuevas avenidas. Rodin y Boudelle la decoraron de mármoles y bronces. La Avenida de Mayo, muy siglo XIX, parece un trozo de Madrid o de París. En el Teatro de la Ópera la temporada se abre en una noche esplendorosa que envidiaría la Viena del imperio. Las bailarinas de la escuela argentina no hubieran desentonado en San Petersburgo de los zares. Con Londres, Nueva York y París, Buenos Aires forma un frente único en el teatro. "La Prensa" y "La Nación" figuran entre los diarios de mayor prestigio y autoridad en el mundo. Por la calle Florida, a las cinco de la tarde desfila una de las poblaciones mejor vestidas que pueda verse en ciudad alguna. El Jockey Club tiene en sus salones la misma luz que el más viejo y mejor de Londres, y mejores pinturas. Es decir: Buenos Aires es una nueva Europa a este lado del Atlántico. Es europea, como no lo es Nueva York. Más europea que española, Buenos Aires es una de las pocas capitales del viejo imperio español sin plaza de toros. La Argentina no tiene Miuras: tiene unos Durhams formidables que se transforman en el Baby Beef de los restaurantes: la mejor carne asada por el hombre a todo lo largo de su historia".
\end{abstract}

Essa imagem de Buenos Aires era cara à certa intelectualidade da Argentina, oposta desde as décadas anteriores aos setores católicos e nacionalistas e ao peronismo ${ }^{368}$ que revelou outra Argentina alheia a estes devaneios europeizantes e elitistas de óperas, clubes e desfiles de moda. Mas o escritor não só reproduz a imagem ${ }^{369}$, também reproduz o cânone literário aceito por esses setores e com ele as representações do processo de formação nacional que ele autoriza, um cânone forjado pela crítica vanguardista dos anos vinte e trinta. Com efeito, fazendo um retrato dos pampas, Arciniegas se desdobra no recurso livresco e cita os "cuatro libros de la pampa": tradição que abrange e reconcilia o pensamento e a estética de Domingo Faustino Sarmiento, José Hernández, Ricardo Guiraldes e Ezequiel Martínez Estrada. Foi dito já como Arciniegas foi sensível também às opiniões do "centenarista" Manuel Gálvez sobre a relação da capital e o interior e às de Scalabrini Ortiz sobre a psicologia do homem argentino ${ }^{370}$. Uma reelaboração desta tradição foi divulgada por Arciniegas nos anos posteriores em seus cursos nas universidades dos Estados Unidos, como pode se verificar na leitura de The green continent (1944) e de El continente de siete colores, aparecidos, segundo testemunho do próprio autor ${ }^{371}$, como resultado desses cursos.

\footnotetext{
${ }^{368}$ Neiburg, Federico, Los intelectuales y la invención del peronismo, Alianza Editorial, Madrid/Buenos Aires, 1988.

${ }^{369}$ Gorelik, Adrián, Miradas sobre Buenos Aires. História cultural y crítica urbana. Buenos Aires. Siglo XXI. 2004.

${ }^{370} \mathrm{E}$ em outros artigos também a textos de Ricardo Rojas.

${ }^{371}$ Cacúa Prada, Antonio, Germán Arciniegas. Su vida contada por él mismo. Bogotá. Universidad Central, Instituto Colombiano de Estudios Latinoamericanos y del Caribe. 1990.
} 


\section{Conclusões.}

Na leitura e análise dos artigos de Arciniegas sobre a Argentina, publicados no jornal El Tiempo de Bogotá, pôde-se observar um exercício da mediação cultural com algumas características que vale a pena salientar. O espetáculo urbano de Buenos Aires produz em Arciniegas uma reação defensiva e nostálgica, uma rejeição à expansão dos arranha-céus que carregava afinidades com correntes de pensamento locais na valorização do legado cultural hispânico, simbolizado nos telhados e restrito então às margens da cidade (Belgrano), o que inevitavelmente ecoa as "orillas" da ensaística juvenil borgiana, ou fora dela, em espaços de lazer (Mar del Plata). Percebeu, mas sem aprofundar, nas divisões sociais que existiam na cidade em começos da década de 1940, e elogiou o progresso material encenado na estrutura urbana de Buenos Aires, imaginando uma Argentina integrada territorialmente, prospera em todos os níveis de sua estrutura social. Defrontado, finalmente, com as culturas populares do porto, Arciniegas apelou às comparações históricas e às versões estetizadas daquilo que lhe pareceu, a começo, "grotesco" e afinal expressão de outra identidade cultural que não a hispânica: a latina.

Arciniegas acompanhou suas observações da vida Argentina com leituras de autores locais que efetivamente informaram e mediaram sua interpretação do país e a forma como a transmitiu aos leitores colombianos. Leituras que formavam, para a década de 1940, um corpus erigido em tradição por alguns dos círculos influentes do âmbito intelectual portenho, e que remonta aos escritores da geração romântica, a começar por Sarmiento, incorporando autores da chamada geração do Centenário, como Manuel Gálvez e Ricardo Guiraldes, e chega às vanguardas criollistas e aos ensaístas da década de 1930, como Martínez Estrada e Scalabrini Ortiz. Houve então um processo de seleção das interpretações sobre a Argentina que operava um efeito de "marcação" e "apropriação"372 dessa tradição literária, associando e autorizando o próprio discurso de Arciniegas na obra dos autores argentinos, apresentados juntos mas parcialmente pelo escritor colombiano.

Nesse aspecto é notável a seleção dos dilemas argentinos trazidos ao campo colombiano, mesmo quando tratados pelos autores com os quais dialogou. A integração nacional, a tradição hispânica, a democracia e a riqueza acompanhadas de ordem social e de disciplina ocuparam a atenção do

372 Bourdieu, Pierre. "Las condiciones sociales de la circulación internacional de las ideas". En: Intelectuales, política y poder. Buenos Aires, Eudeba, 2000. 
escritor colombiano, que não se interessou por abordar problemas fundamentais como a imigração, a experiência social que ela significou e as formas culturais que provocou (como, por exemplo, os conflitos sociais da chamada "década infame" e o próprio tango, que apenas enxergou em versão elitizada, já em espaços de lazer das classes altas e médias); ou a fratura entre a cidade e o porto, a ideia da existência de "duas Argentinas", um poderoso tópico da ensaística argentina a partir dos anos 1930.

Da mesma forma, pode-se ressaltar o diálogo de Arciniegas com as leituras "metropolitanas" sobre a Argentina, que no caso do tango e na ideia orteguiana da nação jovem foram mais ou menos explícitas em seus artigos. A presença dessas leituras poderia se levantar como "elemento perturbador" 373 na relação de alteridade que Arciniegas estabeleceu como "americano" com o país austral. Mas essas leituras não determinaram totalmente a tradução da vida e a evolução argentina produzida por Arciniegas, mas pelo contrário, o colombiano inseriu suas observações e leituras num cerne próprio de imagens caras à sua ensaística (as telhas, as cidades cindidas), outorgando-lhes sentidos culturais, sociais ou históricos plurais. Ou seja, ampliando o espaço semântico das imagens, que em alguns casos, como aquele das calças, foram assinaladas por outros observadores da vida portenha como Alfonso Reyes. A mediação cultural acontecia então em um contexto de circulação de ideias e imagens sobre o país austral.

Outro recurso dessa mediação é a imaginação histórica, que levou o escritor a extrapolar experiências argentinas para outros tempos e espaços, seja o conjunto de cidades americanas, surgidas no século XX, ou bem os portos europeus do século XVI, epifania das quais experimentou na Boca e no delta de El Tigre. Esse recurso, como dito, facilitou o encontro empático com certas dimensões da vida urbana que resultavam "grotescas" e chocantes. Assim, no caso do bairro porto popular, a Boca, onde o olhar estetizante do pintor Quinquela Martín e a imaginação histórica contribuíram à descoberta da Buenos Aires "negra", que se revelou colorida, vigorosa, forte, e nada lânguida, tranquila ou repousada.

A divisão entre a "cidade branca" e a "cidade negra" é central na mediação que fez Arciniegas do mundo portenho para o público colombiano dos anos 1940. Seu cotidiano e sua atenção foram principalmente para o lado branco, europeizado segundo ele o enxergou e festejou como vitória

373 BAGGIO, Kátia Gerab. "Magia e paixão: O México sob olhar de Erico Veríssimo. Proj. História, São Paulo, no. 32, 2006, pp. 79-95. 
da civilização atlântica sobre o influxo selvagem do entorno, do vento do norte. $\mathrm{O}$ escritor constrói desta cidade uma imagem quase utópica, sociedade democrática e rica, sem lutas nem grandes esforços pela riqueza ou a democracia, onde "el oro se ha movido por cauces anchos", onde se "sube al cuarto piso de una casa humilde por escaleras de mármol" e desfruta da vizinhança de um delta composta "por islitas que puede comprar un hombre medianamente rico”.

A imagem de uma nação rica, culta, integrada, onde a riqueza circula sem precisar de luta e agitação, contrastavam grandemente com os conflitos e dificuldades que atravessavam os próprios argentinos desde 1930, mas sobretudo com o que acontecia no país do escritor. Com efeito, violência política e conflitos sociais nos campos e nas cidades cresciam desde a década de 1920. O momento da escrita da maior parte dos textos discutidos aqui, 1940-41, era o tempo da "pausa" aplicada pelo governo de Eduardo Santos, aliás proprietário de El Tiempo, à chamada "Revolución em Marcha" (deslanchada anos antes por Alfonso López Pumarejo, que visava implantar um conjunto de políticas trabalhistas em meio a inúmeros conflitos laborais e uma polarização política cada vez maior). O espaço público colombiano experimentava chamados à mobilização, e à polarização e à violência nos quais descolavam as vozes mais gritantes do panorama nacional. 


\section{CONCLUSÕES}

1.

No curso dessa dissertação mostramos os sentidos, as condições sociais e os mecanismos de um conjunto de atividades que visaram colocar em diálogo as produções artísticas, o mundo editorial e os escritores, e certas tradições de interpretação nacional da Colômbia e da Argentina; atividades desenvolvidas em temporalidades diferentes pelo escritor colombiano Germán Arciniegas entre 1939 e 1959.

Entre 1939 e 1941, como diplomático, Arciniegas promoveu com sentido pedagógico orientado tanto ao público quanto aos próprios artistas colombianos, o conhecimento dos gravuristas argentinos por meio de duas exposições realizadas em Bogotá e Medellín. O escritor-diplomata também projetou uma exposição de livros e arte colombiana em Buenos Aires, ainda que não fosse realizada, e impulsionou a instalação de uma estátua de Francisco de Paula Santander na capital argentina. Essas iniciativas, que tinham um carácter mais diplomático do que pedagógico no sentido de promover determinada imagem, positiva, claro, da tradição cultural e política colombiana, privilegiaram a representação da Colômbia como um país com valiosas heranças do período colonial, como uma vida intelectual e cultural mais antiga do que a Argentina, e ao mesmo tempo uma identidade orgânica com o liberalismo que se havia definido já a partir da independência do país em começos do século XIX.

Ao lado das exposições e instalações propriamente ditas, Arciniegas promoveu suas iniciativas por médio de diferentes mecanismos, como a redação - e o pedido de redação - de artigos em meios colombianos e argentinos, e a alocução de conferências. Mas, sobre todo, o envio de cartas - nossas fontes principais para conhecer essas atividades -, que o escritor encaminhava para seus colaboradores. Nesse sentido é importante mencionar que Arciniegas esteve numa posição favorável para exercer esse tipo de atividades, contando com a dupla condição de escritor e funcionário que o colocou em relação com um universo social local portenho que atingia política e cultura, e com âmbitos nos quais essas dimensões, em ambos os países, estavam muito articuladas como a importantíssima Asociación de Amigos del Arte. No entanto, a condição diplomática não representou um apoio incondicional para o colombiano. Mesmo com colaboradores importantes nas dependências oficias do Ministério de Educação, a Biblioteca 
Nacional e o Ministério de Relações Exteriores, Arciniegas não conseguiu obter os materiais desejados para sua exposição de livros e peças de arte em Buenos Aires, embora a exposições de gravuras e a instalação da estátua foram realizadas. O fundamental a ser sublinhado a respeito disso, é o fato de a Colômbia não contar nesse momento com uma política de diplomacia cultural orientada aos países do continente, no sentido de promover a cultura nacional, deixando a iniciativa aos esforços particulares dos embaixadores e aos adidos.

Segundo observamos na correspondência de Arciniegas, a diplomacia do momento se ocupou mais com a promoção da política de neutralidade defendida pelo governo de Eduardo Santos diante da Segunda Guerra Mundial, e no caso da própria embaixada na Argentina, com as negociações de acordos comerciais. Nesses assuntos, como no policiamento das informações que circulavam na imprensa a respeito da Colômbia, Germán Arciniegas tomou parte, dando continuidade a um acarreia diplomática que havia começado anos antes e que continuaria um par de décadas mais a frente.

Como dito acima, Arciniegas considerou de importância vincular as letras colombianas com à indústria editorial argentina. Por isso, a partir de os anos em que esteve como diplomático em Buenos Aires, construiu um vínculo estreito com as casas editoriais dessa cidade, que foi fundamental para sua consagração entre os públicos e os mercados latino-americanos. Para dar impulso a sua obra, mas também às várias empresas de cultura com as quais esteve comprometido na Colômbia, como revistas e coleções populares de livros, Arciniegas favoreceu os acordos com as casas editoras; acordos que contribuíram para a expansão das atividades e do conhecimento na Colômbia e outros países das próprias coleções das editoras amigas. Arciniegas e os editores hispano-argentinos de Losada e Sudamericana trocaram pela via epistolar, capítulos inéditos para a publicação e assessorias e indicações sobre autores colombianos - entre outras nacionalidades -, para fortalecer um projeto hispano-americanista de orientação liberal, que no caso do colombiano teve um forte carácter partidista. As afinidades ideológicas aproximaram o colombiano desses espaços de sociabilidade que foram as casas editoras. A mediação cultural não é resultado das atividades isoladas de um mediador, embora possamos isola-lo com fins analíticos: ela opera em rede, articulando diferentes instâncias e agentes.

Arciniegas ofereceu aos leitores colombianos imagens e interpretações da cultura e a história argentina. Nos artigos para El Tiempo, que escreveu como relatos de viagem durante suas 
funções diplomáticas e alguns anos depois, na década de 1950, Arciniegas passou uma imagem da Argentina prospera, onde a ordem social não era contestada por um clima de agitação, mas de disciplina e democracia ao mesmo tempo. Uma argentina integrada territorialmente pelo influxo da cidade porto, cerne da atividade cultural e a riqueza do país. Mas também a ideia de uma cidade, Buenos Aires, que se afinal pôde ser reconhecida na latinidade, aparecia no primeiro momento sem marcas do passado espanhol, o que estimulou no escritor colombiano a defesa da tradição hispana dirigida aos leitores bogotanos. Arciniegas fez nesses relatos, pequenos ensaios de imagens recorrentes em sua ensaística, e a partir dos quais pretendia mostrar chaves de leitura do desenvolvimento cultural do continente, como os telhados, as cidades cindidas, a paisagem atravessada por correntes de agua e ar, lidas como influxos culturais. Nesses relatos Arciniegas operava uma seleção de assuntos sobre os quais se debruçaram os intérpretes da cultura argentina da primeira metade do século XX, fazendo leituras fragmentadas, mas orientadas segundo um critério próprio, atentando para os problemas comuns que ele enxergava entre a Colômbia e a Argentina.

\section{2.}

No conjunto de assuntos mencionados acima, vários problemas transversais a respeito das mediações culturais merecem ser destacados e comentados. O primeiro deles é a relação entre mediação cultural e política, que se desdobra em vários pontos. Em primeiro lugar no fato de existir uma clara influência da conjuntura internacional sobre as condições das atividades de Arciniegas em relação à cultura argentina, e fundamentalmente às apresentações e aos intercâmbios que visou promover entre essa e os âmbitos intelectuais colombianos. Conjuntura, a começar pela Segunda Guerra Mundial, de uma intensa propaganda que visava dar força e realidade à ideia de América como uma unidade histórica, e até cultural, onde intervinham diferentes versões orientadas por objetivos divergentes, entre os quais destacamos a defesa da democracia diante das forças e dos seguidores do eixo. Nesse sentido a defesa do liberalismo colombiano, que Arciniegas associava a uma dimensão "continentalista" não podia ter outro sentido. Após a Guerra, o auge de governos militares em ambos os países, e na Espanha, fez com que a defesa do liberalismo perdesse espaço - como também aconteceu em outros países -, afetando a circulação dos bens culturais associados com essa orientação ideológica (como foram os livros do escritor) e acarretando dificuldades econômicas e até autocensura entre os próprios 
editores argentinos. As cartas trocadas chegaram a usar certas estratégias, um pouco inocentes, de codificação.

Em segundo lugar queremos salientar que o fôlego das trocas culturais durante a Segunda Guerra Mundial, vinha sendo ganho a partir da década de 1930, impulsionado por diferentes governos especialmente pelo brasileiro, o argentino, o chileno, e desde duas décadas antes, pelo mexicano -, que desenvolveram projeções de diplomacia cultural propriamente dita, articuladas e centralizadas. As trocas intelectuais anteriores à década de 1930, a exceção do caso mexicano, têm sido analisadas como formas de um latino-americanismo "desde abajo" "374, no sentido de não contar com o planejamento e a estrutura dos governos. Redes científicas, teosofistas, revolucionárias e estudantis que foram criando redes de mediação nas décadas de 1910 e 1920, mas que já à beira dos anos 30 começaram a se desintegrar em decorrência do auge de governos autoritários que impediram seu proselitismo, ou porque foram incorporadas aos circuitos partidários e aos serviços oficiais, como aconteceu com o próprio Arciniegas: líder estudantil nos anos 1920; e diplomata, representante à Câmara e Ministro nos anos 30 e 40. Já na década seguinte, as atividades do escritor em relação às trocas passaram de novo aos âmbitos privados, mas o carácter contestatário do latino-americanismo desde abajo estava longe das atividades do escritor e seus colaboradores, consagrados e ocupando espaços de domínio nos campos culturais do continente como revistas e jornais - já que não da política. Isso último é especialmente pertinente para o caso argentino, onde as empresas culturais que acolheram as trocas não foram patrocinadas pelo Estado - por exemplo, as editoras -, como sim aconteceu na Colômbia onde mesmo sem se constatar um programa de diplomacia cultural existiram órgãos de integração intelectual como a Revista de las Indias.

\section{3.}

A relação que construiu Arciniegas com a cultura argentina no intuito de apresentá-la ao público colombiano implicou vários movimentos: a comparação com a cultura colombiana segundo ele próprio a entendia, a seleção de elementos que considerou pertinentes para serem transmitidos, e uma série de "deturpações" sobre o conjunto de esses elementos, comuns nos episódios de

\footnotetext{
${ }^{374}$ Bergel, Martín. “América Latina, pero desde abajo: prácticas y representaciones intelectuales de un ciclo histórico latinoamericanista, 1898-1936". Cuadernos de Historia, No. 36. Departamento de Ciencias Históricas, Universidad de Chile, 2012, p. 7-36.
} 
mediação cultural. O escritor conciliou nesse caso, como pretendeu fazê-lo no conjunto de sua obra, o legado colonial e o liberalismo, como faróis da vida americana.

Arciniegas contrastou as tradições culturais de ambos os países em função de sua relação com a matriz hispânica, indicando a presença muita mais forte na Colômbia do que na Argentina de um legado de atividade cultural, universitária, artística, editorial e jornalística, do período colonial. O contraste foi reforçado pela observação da arquitetura dominante na cidade. A crítica explícita que Arciniegas fez à cultura argentina, mas dirigida ao público colombiano, estava orientada à manutenção e à renovação dessa matriz hispânica na cultura nacional.

Tal posicionamento e a imagem contrastada das tradições nacionais levaram Arciniegas a dialogar, na década de 40, com os autores argentinos mais preocupados pela perda dessa tradição, associados nas histórias da literatura à geração do centenário e ao criollismo da década de 1920, assim como ao ensaio dos anos 1930, mas sem mencionar o processo daquela perda, ou seja, sem problematizar o problema fundamental da imigração da virada do século XIX pro XX. Esse desfase no tratamento dos discursos de interpretação cultural foi reforçado depois, quando incorporou o problema da imigração associando-o à constatação de uma matriz de latinidade que não de hispanismo -; mas sem reconhecer os problemas encarados pelo próprio ensaísmo argentino da década de 50, que refletia sobre novos processos migratórios, dessa vez internos, e as transformações decorrentes sobre a nacionalidade.

Mesma coisa pode ser dita sobre as opiniões do colombiano a respeito do sucesso do liberalismo no país austral, incontestado nos textos de Arciniegas, mas dúbio no ensaísmo argentino a partir da década de 1930 e ainda mais nos anos seguintes. Essa "assimilação fragmentária dos repertórios alheios" refletia os "compromissos do mediador"375 com suas próprias posições no espaço nacional colombiano, na defesa do ideário republicano em meio à uma animada concorrência pela hegemonia levantada por forças dentro e fora do próprio partido ao qual pertencia. Num clima de intensa agitação social, Arciniegas passava para o público colombiano uma representação da Argentina como um país próspero, integrado, democrático, onde as diferenças sociais, se nítidas, eram assumidas naturalmente, pois a riqueza iria atingindo os

\footnotetext{
375 Pellegrino Soares, Gabriela. "História das ideias e mediações culturais: breves apontamentos". Em: Junqueira, Marie Ann \& Scatena Franco, Stella Maris (org.) Cadernos de Seminário de Pesquisa. V. II. São Paulo: USPFFLCH. Editora Humanitas, 2011, pp. 87-97.
} 
setores populares. Nas cartas ao presidente Eduardo Santos, Arciniegas mostrava como a agitação durante a guerra era maior, e a presença de propagandistas críticos ao liberalismo tomava força no país.

Significativamente Arciniegas fez para o público argentino uma apresentação da tradição política colombiana orientada na mesma direção: mostrar como o espírito da capital havia integrado o país numa cultura democrática e civil, onde as guerras respondiam a ideais nacionais, lideradas por homens de letras e armas nos quais as primeiras levariam a vantagem. Bogotá, "a cidade mais pacífica do mundo", estava, no entanto, a poucos anos de sofrer seu maior levantamento popular. 


\section{Bibliografía}

Arquivos:

Biblioteca Nacional de Colômbia (BNC). Fondo Germán Arciniegas (FGA). Bogotá, Colombia.

Biblioteca Nacional de Maestros. Archivo Personal Ricardo Levene. Buenos Aires, Argentina.

Bibliografía sobre Germán Arciniegas:

Arbeláez, Carlos. Um proyecto americanista por correspondência. Tese de graduação em sociologia. Bogotá, Pontificia Universidad Javeriana, 2014.

Cacúa Prada, Antonio. Germán Arciniegas, su vida contada por él mismo. Bogotá. Universidad Central. 1991.

Campa, Annunziata. German Arciniegas: l'itinerario intellettuale di un latinoamericano in Italia, Annali d'Italianistica, num. 1, vol.14, 1996.

Cobo Borda, Juan Gustavo (compilador). Una visión de América. La obra de Germán Arciniegas desde la perspectiva de sus contemporáneos. Bogotá. Instituto Caro y Cuervo, 1990.

Cobo Borda, Juan Gustavo. "Las revistas de Arciniegas". En: La otra literatura latinoamericana. Bogotá: Procultura. 1982.

Bogotá. Planeta.1990.

, Germán Arciniegas. 90 años escribiendo. Un intento de bibliografía.

, Germán Arciniegas. Cronología y Bibliografía. Bogotá. Planeta. 1990.

, "Germán Arciniegas: La historia, esa otra forma de ficción”. Revistas del

Colegio Mayor de Nuestra Señora del Rosario. Bogotá. Vol. 83. No. 552, 1990, pp. 7-16.

, Germán Arciniegas. En: Silva, Arciniegas, Mutis, García Márquez y

otros escritores colombianos. Bogotá: Biblioteca Familiar de la presidencia de la República. 1997.

Fajardo, Alicia. "Historia de un ¿historiador?” Em: Boletín Cultural y Bibliográfico. Vol. XXV. No. 16. Bogotá. Banco de la República. 
Georgescu, Paul Alexandru. “Germán Arciniegas y la narración Histórica” En: Correo de los Andes. Bogotá. No. 46. 1987.

, "Germán Arciniegas y el conocimiento múltiple de Hispanoamerica" En: Nueva visión sistemática de la narrativa hispanoamericana. Caracas. Monte Ávila Editores. 1989

Gilard, Jaques. "Las revistas de Arciniegas: la inteligência y el poder". En: Renaud, Maryse. En torno a Germán Arciniegas. Poitiers: Centre de Recherches Latino-americaines. U. de Poitiers, 2002.

Lagmánovich, David. "Arciniegas: del relato al ensayo". Anales de literatura hispanoamericana, 6. 1981.

Moreno Villa, José. Encuentros con Gabriela Mistral y Germán Arciniegas. En: Los autores como actores y otros intereses literarios de aquí y de allá. México. Fondo de Cultura Económica. 1951

Pabón Pérez, Hugo Leonardo, Bibliografía de y sobre Germán Arciniegas. Bogotá. Instituto Caro y Cuervo. 2001.

Rivas Gamboa, Ángela. “Un estudiante-maestro”. Historia Crítica. Bogotá. Uniandes. 2002.

Robb, James Wills. "Imágenes de América en Alfonso Reyes y en Germán Arciniegas", Humanitas, Monterrey, 1964, págs. 255-269.

, "Variedades del ensayismo en Alfonso Reyes y Germán Arciniegas" Thesaurus. Tomo XXXVI. Bogotá. 1981.

"Alfonso Reyes y Germán Arciniegas: corresponsales e hispanoamericanistas afines”. Thesaurus. Tomo XXXVIII. Bogotá, 1983.

Sáenz Rovner, Eduardo. Germán Arciniegas: entre la libertad y el establecimiento. Historia Crítica, No. 21. Bogotá. Universidad de los Andes. 2001.

Tamayo, Martha Lúcia. Germán Arciniegas y Macedonio Fernández, vidas paralelas posmodernas. Bogotá. Universidad Javeriana. 2006.

Triviño Anzola, Consuelo. De Montaigne a Arciniegas: la escritura y la construcción del ser americano. Cuadernos Hispanoamericanos 551-552, pp. 61-70.

Zaitzeff, Sergei. "El joven Arciniegas a través de su correspondencia con Carlos Pellicer. Historia Crítica, No. 21, 2001, p. 71-75. 
. “Germán Arciniegas y Gabriela Mistral: contactos epistolares”. Anthropos. No.

234, 2014.

Bibliografía de Germán Arciniegas.

Libros :

América, tierra firme. Santiago de Chile. Ediciones Ercilla. 1937.

Diario de un peatón, Bogotá, Imprenta Nacional, 1936

Entre la libertad y el miedo. Buenos Aires. Sudamericana. 1956.

Entre la libertad y el miedo. México: Cuadernos, 1952.

Estampas del Paraguay. Bogotá: Uniandes, 2015.

Este pueblo de América. México: FCE, 1945.

Jiménez de Quesada. Bogotá: A.B.C., 1938.

La universidad colombiana, Imprenta Nacional, Bogotá, 1932

Memorias de un congresista. Bogotá. Cromos. 1933.

The Caribean sea of the New World. Ian Randle Publishers.

The Green Continent: A Comprehensive View of Latin America by Its Leading Writers. New York. Knopf, 1944.

The knight of El Dorado. The Tale of Don Gonzalo Jimenez de Quesada and His Conquest of New Granada, Now Called Colombia. New York. Viking Press, 1942.

Artígos:

"Benito Quinquela: el más fuerte y vigoroso pintor del puerto de Buenos Aires", El Tiempo, 26/05/1940,

“El poeta de las maderas. Víctor Delhez y su obra”. El Tiempo, 09/02/1941.

“Los caballeros de la orden del tornillo", El Tiempo, 09/06/1957. 
"No existe un nuevo orden sino una nueva orden nazi". Entrevista con Agustín Ferraris. Hombre de América. Ano II, Vol. 9, abril de 1941. pp. 8-9.

"Santander o el nacimiento de la consciencia civil en América". La Prensa, 05/05/1940.

"Santander y la lucha por la libertad después de la independencia". Revista de las Indias No. 19, Bogotá, Junio de 1940, pp. 319-344,

"Santander y la lucha por la libertad después de la independencia". Boletín de la Academia Nacional de la Historia vol. 41, Buenos Aires: 1940, pp. 163-179.

“Desde Buenos Aires. Ambiente de altiplano". El Tiempo, 05/06/1957

"Viaje por América. Reencuentro con Buenos Aires". El Tiempo, 28/06/1956.

"Viaje por América. Reencuentro con la Provincia". El Tiempo, 03/07/1956.

"Buenos Aires tiene cuarenta años". El Tiempo, 21/09/1941.

"Diario de un peatón: las piedras de Cacheuta". El Tiempo, 03/03/1941.

“Gacetilla de Buenos Aires. Cosas de la lengua española”. El Tiempo, 06/07/1956.

"Inglaterra país de segunda mano. Londres es una tienda de antigüedades". El Tiempo, 16/08/1931.

“Un mundo a bordo: El que no pudo ver a Evita Perón”. El Tiempo. 30/08/1947.

Correspondência publicada de Germán Arciniegas:

Cobo Borda, Juan Gustavo (Comp.) Arciniegas de cuerpo entero. Bogotá. Planeta. 1987.

, Arciniegas corresponsal del mundo 1928-1989. Bogotá. Fundación Santillana para Iberoamérica. 1990.

Esquenazi Mayo, Roberto. Experiencias de toda una vida: Cartas de Germán Arciniegas. Universidad de Colorado. Departamento de Español. 1997.

Zaitseff, Sergei (Comp.) Algo más de la experiencia americana. Correspondencia entre Alfonso Reyes y Germán Arciniegas. México. El Colegio Nacional. 1998.

Correspondencia entre Carlos Pellicer y Germán Arciniegas, 1920-

1974. México. Consejo Nacional para la Cultura y las Artes/ Herederos de Germán Arciniegas. 2002. 
, México es cosa mía. Reyes, Mistral Arciniegas: epistolário de Germán Pardo García. México: El Colegio Nacional, 2011.

Bibliografía Geral:

Abbot, Andrew, Department and discipline: Chicago sociology at one hundred. Chicago, 1999.

Abellán, Luis. La Idea de América: origen y evolución. Madrid: Istmo.

Aguilera Peña, Mario, Insurgencia urbana em Bogotá. Bogotá. Colcultura. 1997.

Arias Trujillo, Los leopardos. Una historia intelectual de los años veinte. Bogotá. Uniandes, 2013.

Arlt, Roberto. Paisaje em las nubes. Crónicas en El Mundo, 1937-1942. Buenos Aires. FCE. 2009.

Artundo, Patricia. Mario de Andrade e a Argentina. Um pais e sua produção cultural como campo de reflexão. São Paulo: Edusp.

Ayala Diago, César Augusto. "La tradición también influye. Remozamiento político e ideológico de la derecha colombiana en los años treinta". Em: Acosta, Carmen Elisa et. Al. Independencia, independências y espacios culturales. Bogotá: Universidad Nacional de Colombia. 2009.

Baggio, Kátia Gerab, “A utilização de relatos de viagem como fontes históricas para investigar os intercâmbios intelectuais entre o Brasil e a América Hispânica”, em Bohoslavsky, Ernesto, Geoghegan, Emilce y González, María Paula (coords.), Los desafíos de investigar, enseñar y divulgar sobre América latina. Actas del taller de reflexión TRAMA. Los Polvorines, Universidad Nacional de General Sarmiento, 2011.

São Paulo, no. 32, 2006, pp. 79-95.

. "Magia e paixão: O México sob olhar de Erico Veríssimo. Proj. História, , "Ronald de Carvalho e Toda a Amèrica: diplomacia ensaísmo, poesia e impressões de viagem na sociabilidades intelectual entre Brasil e a Hispano-América" Em: Bendicho Beired, José Luis, Capelato, Maria Helena e Coelho Prado, Maria Ligia, Intercâmbios políticos e mediações culturais nas Américas. LEHA. USP. São Paulo. 2011.

Ballent, Anahí. "Mar del Plata: croquis en la arena". Em: ALTAMIRANO, Carlos (ed.) Argentina em el siglo XX...Op. Cit, 
Barrera Aguilera, Óscar Javier, "Folclor, indigenismo y mestizaje durante la República Liberal", Maguaré, No. 23, 2009, pp. 133-153.

Bergel, Martín, Martínez Mazzola, Ricardo. América Latina como práctica. Modos de sociabilidad intelectual de los reformistas universitários (1918-1930). Em: Altamirano, Carlos (dir) Historia de los intelectuales en América Latina. Vol. II. Madrid, Katz, 2010. pp. 119-145.

Bergel, Martín. “América Latina, pero desde abajo: prácticas y representaciones intelectuales de un ciclo histórico latinoamericanista, 1898-1936". Cuadernos de Historia, No. 36. Departamento de Ciencias Históricas, Universidad de Chile, 2012, p. 7-36.

Bermúdez Liévano, Andrés. "La literatura colombiana bajo la lupa del franquismo". Arcadia, 03/09/2011.

Betancourt Mendieta, Alexander. Historia y nación. Tentativas de la escritura de la historia en Colombia. Medellín. La Carreta. 2007.

Bethell, Leslie. O Brasil e a idéia de "América Latina" em prespectiva histórica. Estudos históricos Vol. 22. No. 44.

Botrel, Jean François. "Cosmopolitismo e mediación cultural em la España del siglo XIX”. Península, Revista de Estudios Ibéricos. No. 4, 2007.

Bourdieu, Pierre. "Las condiciones sociales de la circulación internacional de las ideas". En: Intelectuales, política y poder. Buenos Aires, Eudeba, 2000.

Braun, Herbert. Mataron a Gaitán. Vida pública y violência urbana em Colombia. Bogotá. Punto de Lectura, 2013.

Brown, Gerardo y Jassey, William. Introducción al ensayo hispanoamericano. Nueva York. Las Américas Publishing. 1968.

Bushnell, David, "La guerra civil española, 1936-1939. Perspectivas colombianas” Em: Ensayos de historia política de colombia, siglos XIX y XX. Bogotá, La Carreta. 2006.

1984.

, Eduardo Santos y la política del Buen Vecino. Bogotá. El Áncora Editores,

Caballero Calderón , Eduardo, Ancha es Castilla, Buenos Aires: Losada, 1954.

Caldas, Tito Lívio. Industria editorial, cultura y desarrollo em Colombia. Bogotá. Minerva. 1970.

Capelato Rolim, Maria Helena. Modernismo latino-americano e construção de identidades através da pintura. Revista de História. São Paulo. No. 135. 2005-2. pp. 251-282. 
Castro Gomes, Ângela de. "Escrita de si, escrita da Historia: a título de prologo". Em: Castro Gomes, Ângela de (org.). Escrita de si, escrita da historia. Rio de Janeiro, FGV, 2004.

- "Nas malhas do feitiço: o historiador e os encantos dos arquivos privados". Estudos Históricos. No. 21, 1998.

Cataño, Gonzalo. La introducción del pensamiento moderno en Colombia. El caso de Luis E. Nieto Arteta. Bogotá. Universidad Externado de Colombia. 2013.

Cobo Borda. Juan Gustavo, "Historia de la industria editorial colombiana" En: Cobo Borda, Juan Gustavo (editor), Historia de las empresas editoriales de América Latina. Siglo XX. Bogotá, CERLALC, 2000, pp. 161-188.

Colombi, Beatriz. Viaje Intelectual. Migraciones y desplazamientos en América Latina (18801915). Beatriz Viterbo Editora. Rosario, 2004.

Crespo, Regina, "Cultura e política: José Vasconcelos e Alfonso Reyes no Brasil (1922-1938), Em: Revista Brasileira de História, Vol. 23, No. 45, 2003, pp, 187-208.

, "Entre porteños y cariocas. Alfonso Reyes embajador" consultado o 30/11/12 em http://cvc.cervantes.es/literatura/escritores/a_reyes/entorno/crespo.htm;

Dabusti De Muñoz, María Teresa: “Trayectoria de Lorenzo Luzuriaga en Losada, una editorial en el exilio". En: Revista de Historia Contemporánea, N9-10, Sevilla, 1999-2000.

De Diego, José Luis (dir.) Editoriales y políticas editoriales en Argentina, 1880-2000, Buenos Aires, Fondo de Cultura Económica. 2006.

De Diego, José Luis. “Cortázar y sus editores”. Orbis Tertius. Vol. 14, No. 15, 2009.

Dumont-Quessard, Juliette. De la coopération intellectuelle à la diplomatie culturelle. Les voies/x de l'Argentine, du Bresil et du Chili (1919-1946). Tese de doutorado. Université Sorbonne Nouvelle-Paris 3. 2013.

Ellison, Fred, Alfonso Reyes e o Brasil, Río de Janeiro, Topbooks, 2002.

Espagne, Michel. "Du creuset espagnol à 1Espagne hors les murs". Mélanges de la Casa de Velásquez . 2008. Consultado o 15/11/2013. URL: http://mcv.revues.org/775.

Espósito, Fabio, “Los editores españoles en la Argentina: redes comerciales, políticas y culturales entre España y la Argentina (1892-1938). En: Altamirano, Carlos (director), Historia de los intelectuales en América Latina. v II. Buenos Aires, Katz, 2010, pp. 515-537.

Falcón, Alejandrina. "Debates sobre las lenguas nacionales en la revista Sur (1931-1945), Fragmentos, número 37, Florianópolis, julio-dezembro 2009, p. 181-201. 
Fontes Piazza, Maria Fátima. "Politicas de amizade: Portinari e o mundo cultural iberoamericano". Topói. V. 7. No. 12. Janeiro-Julho 2006, pp. 222-246.

Fraiz, Pricilla. “A Dimenssão autobiográfica dos arquivos pessoais”. Estudos Históricos. No, 21, 1998, pp.55-87.

Freitas Dutra, Eliane de, "Projetos editoriais e exposições do livro no espaço latino-americano: intelectuais e trocas culturais. 1930-1940" La Plata, 31 de octubre al 2 de noviembre de 2012 sitio web: http://coloquiolibroyedicion.fahce.unlp.edu.ar

Garramuño, Florencia, Modernidades primitivas. Tango, samba y nación, Buenos Aires, Fondo de Cultura Económica, 2007.

Gergardt, Federico, "Todos los puentes El Puente. Una colección en tres épocas”. Olivar, V.12, N. 16, 2011, pp. 241-283.

Giuliani, Alejandra, Libros o alpargatas. "El comienzo de una historia. Editores, escritores y política en la Argentina de 1945”. Prólogos, v. II. 2009, pp. 59-78.

Glondys, Olga. La guerra fría cultural y el exilio republicano español. Madrid. CSIC. 2012.

Gomez, Daniela, Cómo te olvidan. La historia de Teresa Santamaría de González, Medellín, Letra y Pulso, Instituto de Cultura y Patrimonio de Antioquia, 2014.

Gómez, Laureano. El mito de Santander. Bogotá: Editora Revista Colombiana. 1966.

Gorelik, Adrián, "Buenos Aires y el país: figuraciones de una fractura" En: ALTAMIRANO, Carlos (ed.). Argentina en el siglo XX. Buenos Aires, Ariel, 1999, pp, 136-161.

Aires. Siglo XXI. 2004.

Miradas sobre Buenos Aires. História cultural y crítica urbana. Buenos , A Buenos Aires de Ezequiel Martínez Estrada. Tempo Social. São Paulo, V.

21, No. 2, 2009.

Gutierrez Girardot, Rafael. La imagen de América en Alfonso Reyes.Madrid. ínsula: 1955.

Gutiérrez, Leandro e Romero, Luis Alberto, Sectores populares, cultura y política. Buenos Aires en la entreguerra. Buenos Aires, Siglo XXI, 2007.

Hanke, Lewis, ¿Tienen las Américas una Historia común? México. Editorial Diana. 1996.

Hernández García, José Ángel. La guerra civil española y colombia. Influencia del principal conflito mundial de entreguerras em Colombia. Bogotá. Universidad de La Sabana. Editorial Carrera 7ma. 2006. 
Jaimes, Héctor. La reescritura de la historia en el ensayo hispanoamericano. Editorial Fundamentos. 2001.

Jannello, Karina. "Los intelectuales de la Guerra Fría. Una cartografía latinoamericana (19531962). Políticas de la memoria. No. 14. 2013-2014. Buenos Aires. pp. 79-101.

Joyeux, Beatriz. “Les tranferts culturels. Un discours de la méthode. Hyphothèses. 2002/1.

Larraz, Fernando, Una historia trasatlántica del libro. Relaciones editoriales entre España y América Latina (1936-1950). Gijón, Trea, 2010.

Martelli, Sixto. Meditación acerca de lacto de grabar. Um ejemplo del primer plano: Víctor Delhez. Revista de las Indias, vol. 10, No. 30, junho 1941, pp. 72-80.

Martínez Blanco, Maria Teresa. Identidad cultural hispanoamericana. Europeísmo y originalidad americana. Madrid. Universidad Complutense. 1989.

Martínez, Frederic. El nacionalismo cosmopolita. Bogotá. Banco de la República. 1997.

Martins Venancio, Giselle. "Cartas de Lobato a Viana. Uma memória epistolar silenciada pela história”. Em: Castro Gomes, Ângela de (org.). Escrita de si. Escrita da história...Op. Cit. pp.111-137.

Mayor Mora, Alberto, Ciencia y utopia. Biografía intelectual y política de Alejandro López, Medellín. EAFIT, 2001.

Mead, Robert y Earle, Peter. Historia del ensayo hispanoamericano. México. Ediciones de Andrea. 1956.

Medina, Álvaro. El arte colombiano en los años veinte y treinta. Bogotá. Colcultura. 1995.

Melo, Jorge Orlando. "Bolívar en Colombia: conservador y revolucionario". Disponible en: http://www.jorgeorlandomelo.com/bolivarcolombia.htm

, "La literatura histórica en la Republica". Em: Historiografia colombiana. Realidades y perspectivas. Bogotá: Autores Antioqueños. 1996.

Vieco. , Historiografía colombiana: realidades y perspectivas. Medellín: Martín

Meo Laos, Verónica. Vanguardia y renovación estética. Asociación Amigos del Arte (19241942). Buenos Aires, CICCUS, 2007.

Miceli, Sergio. Vanguardas em retrocesso. São Paulo. Companhia das Letras. 2013.

Miramón, Alberto. Vida ardiente de Manuelita Sáenz. Bogotá: Librería Suramericana, 1944. 
,Los septembrinos. Bogotá: A.B.C., 1939.

Molina, Gerardo. Las ideas liberales en Colombia. V.II. 1915-1934. Bogotá: Tercer Mundo, 1974.

Molloy, Silvia, "Victoria viajera: crónica de un aprendizaje. En: OCAMPO, Victoria, La viajera y sus sombras. Crónica de u aprendizaje. Buenos Aires. Fondo de Cultura Económica. 2010.

, Ciudades traducidas: Nueva York en Victoria Ocampo. Prismas. Revista de historia intelectual, No. 6, 2002, p. 65-77.

Myers, Jorge, "El intelectual-diplomático: Alfonso Reyes, sustantivo" En: Altamirano, Carlos (director). Historia de los intelectuales em América Latina, v. II. Los avatares de la "ciudad letrada" en el siglo XX. Buenos Aires, Katz, 2010. pp. 82-97.

, "Pasados en pugna: la difícil renovación del campo histórico argentino entre 1930 y 1955". En: Neiburg, Federico, Plotkin, Mariano. Intelectuales y expertos. La constitución del conocimiento social en la Argentina. Buenos Aires, Paidós, 2004, pp. 67-106.

, Gênese "ateneísta" da história cultural latino-americana. Em: Tempo social. Revista de sociologia da USP, 17. São Paulo. 2005.

Neiburg, Federico, Los intelectuales y la invención del peronismo. Madrid/Buenos Aires, Alianza Editorial, 1998.

Noiriel, Gerard, Espagne, Michel. "Tranferts culturels: léxemple franco-allemand. Entretien avec Michel Espagne. Em: Genèses, 8, 1992.

Osorio Lizarazo, José Antonio. El fundador civil de la República. Bogotá: Editorial del Comercio, 1940.

Oviedo, José Miguel, Breve historia del ensayo hispanoamericano. Madrid, Alianza Editorial, 1991.

Pabón Nuñez, Lucio. "Relaciones culturales entre Colombia y la Argentina". En Boletín de la Academia Colombiana, Bogotá, XXV, 1975, págs. 244-251.

Palmeira, Miguel. Arquivos pessoais e história da história: a propósito dos Finley Papers. Em: I. Travancas; J. Rouchou; L. Heymann. (Org.). Arquivos pessoais: reflexões multidisciplinares e experiências de pesquisa. Rio de Janeiro: FGV, 2014, p. 79-99.

Pellegrino Soares, Gabriela. "História das ideias e mediações culturais: breves apontamentos". Em: Junqueira, Marie Ann \& Scatena Franco, Stella Maris (org.) Cadernos de Seminário de Pesquisa. V. II. São Paulo: USP-FFLCH. Editora Humanitas, 2011, pp. 87-97. 
Pereira Theodozio, Vera María. Autor \& edição: três sub-séries da Correspondência João Guimarães Rosa (1957-1967). Tese apresentada para obter o título de Doutor em História. São Paulo. USP. 2011.

Perry, Oliverio. Quien es quien en Colombia. Bogotá. Oliverio Perry, 1944.

Pita, Alexandra. La discutida identidad latinoamericana: debates en el Repertorio Americano, 1938-1945. En: Granados, Aimer \& Marichal, Carlos (coordinadores). Construcción de la identidad latinoamericana. Ensayos de historia intelectual. Siglos XIX y XX. México: El Colegio de México. 2004. pp. 241-263

Politicas de la memoria. "Dossier: La correspondencia en la historia política e intelectual latinoamericana." No. 15. Buenos Aires. 2014-2015.

Posada Carbó, Eduardo. “Colombia en Cesarismo Democrático”. Em: Carrera Damas, Germán. Mitos políticos en las sociedades andinos. Orígenes, invenciones, ficciones. Lima: IFEA, Editorial Equinoccio, 1996.

Prochasson, Christophe. "Atenção: verdade! Arquivos privados e renovação das práticas historiográficas”. Estudos Históricos. No, 21, 1998, pp. 105-119.

Restrepo Yusti, Manuel. "La Revista de las Indias, un proyecto de ampliación de fronteras. Boletín Cultural y Bibliográfico. Vol. 27, No. 23, pp. 25-41.

Reyes, Alfonso, “Palabras sobre la nación argentina". En: Obras Completas de Alfonso Reyes IX, Fondo de Cultura Económica, México, 1981, p. 28-41.

Reyes, Emma. Memorias por correspondência. Bogotá: Laguna Libros, 2012.

Rojas, Rafael. "Las desventuras de un género". Prismas. Revista de Historia Intelectual. Quilmes. 2007.

Romero, Luis Alberto. Breve historia contemporánea de la Argentina. Buenos Aires. FCE, 1994.

Rubiano Muñoz, Rafael. "Baldomero Sanín Cano y la revista Nosotros (1907-1943). Intercambio y redes culturalese intelectuales". Anuario Colombiano de Historia Social y de la Cultura, vol 41, No. 1, 2014.

, “Baldomero Sanín Cano en La Nación de Buenos Aires (1909-1957).

Prensa, diplomacia e análisis político internacional”. Historia y Sociedad No. 25, Medellín, 2013, pp79-106.

Ruiz Galvete, Marta. “Cuadernos del Congreso por la Libertad de la Cultura : anticomunismo y guerra fría en América Latina “, El Argonauta español [En ligne], 3 | 2006, consultado

11/09/2013. URL : http://argonauta.revues.org/1095. 
Saítta, Sílvia. "Modos de pensar lo social. Ensayo y sociedad en la Argentina (1930-1965). Em: Neiburg, Federico; Plotkin, Mariano. Intelectuales y expertos. La constitución del conocimiento social en la Argentina. Buenos Aires, Paidós, 2004, pp. 107-146.

Santos, Eduardo. "Elogio del general Santander". Em: Etapas de la vida colombiana. Discursos (1938-1942). Bogotá: Ministerio de Educación. 1946.

Sarlo, Beatriz. La perspectiva americana en los primeros años de Sur. En: Altamirano, Carlos y Sarlo, Beatriz. Ensayos Argentinos. De Sarmiento a la vanguardia. Buenos Aires. Ariel. 1997. Pp. 261-268.

Visión, 1988.

, Una modernidad periférica. Buenos Aires 1920-1930. Buenos Aires. Nueva

Scalabrini Ortiz, Raúl. El hombre que está solo y espera. Buenos Aires, Librerías Anaconda, 1933

Senkman, Leonardo, "El nacionalismo y el campo liberal argentinos ante el neutralismo: 19391943". Estudios Interdisciplinarios de América Latina y el Caribe, Vol. 6, $N^{o} 1$, enero-junio de 1995, pp. 23-50.

Silva, Renán. República Liberal, intelectuales y cultura popular. Medellín. La Carreta. 2005.

Skirius, John. El ensayo hispanoamericano en el siglo XX. México. Fondo de Cultura 1981.

Sorá, Gustavo, "Misión de la edición para una cultura en crisis. El Fondo de Cultura Económica y el americanismo en Tierra Firme”. En: Altamirano, Historia de... Op. Cit. Pp. 537-567.

, "Edición y política. Guerra Fría en la cultura latinoamericana de los años '60". Revista del Museo de Antropología. Universidad Nacional de Córdoba. No. 1. 2008.

, "Editores y editoriales de ciencias sociales: un capital específico". En: Neiburg, Federico y Plotkin, Mariano, Intelectuales y expertos... Op. Cit. pp. 265-292.

Sowell, David. Artesanos y política en Bogotá. Bogotá. Pensamiento Crítico. 2006.

Suárez Salazar, Luis \& García, Tania, Las relaciones interamericanas: continuidades y cambios. Buenos Aires. CLACSO, 2008.

Subercaseaux, Bernardo, "Editoriales y círculos intelectuales en Chile (1930-1950)". En: Altamirano, Carlos, Historia de los intelectuales... Op. Cit, pp. 567-580.

Torres Del Río, César. "Siglo XX: relaciones y políticas" En: Asociación Argentina de Colombia, Argentinos y colombianos. Historias y encuentros. Bogotá. La Asociación, 1994, pp, 62-157. 
Tovar Zambrano, Bernardo. "Porque los muertos mandan. El imaginario patriótico de la historia colombiana”. Em: Ortiz, Carlos Miguel \& Tovar Zambrano, Bernardo. Pensar el pasado. Bogotá: Universidad Nacional de Colombia, 1997. p. 125-169

Vanderhuck Arias, Felipe, La literatura como oficio: José Antonio Lizarazo 1930-1946. Medellín. La Carreta Editores. Universidad Icesi. 2012.

Vitier, Medardo. Del ensayo americano. México. Fondo de Cultura Económica. 1945.

Yankelevich, Pablo. "México-Argentina. Itinerario de una relación" Em: TZINTZUN, Revista de Estudios Históricos, No. 45, 2007, pp, 83-104.

, Miradas australes. Propaganda, cabildeo y proyección de la Revolución Mexicana en el Rio de la Plata, 1910-1930. INEHRM, México 1997;

Zaitseff, Sergei, "Alfonso Reyes en Brasil a través de su correspondencia con Genaro Estrada". Anuuario brasileño de estudios hispánicos, No.4. 1994.

NRFH, No. 37.

, “Alfonso Reyes en París a través de su correspondencia con Gerano Estrada".

,"El joven Arciniegas a través de su correspondencia con Carlos Pellicer. Historia Crítica, No. 21, 2001, p. 71-75. 